\title{
EFEITO DA TREALOSE NA MANUTENÇÃO DA VIABILIDADE DE CÉLULAS DE LEVEDURAS DESIDRATADAS PELO PROCESSO DE LIOFILIZAÇÃO
}

\author{
ANDRÉ RICARDO ALCARDE
}

Engenheiro Agrônomo

Orientador: Prof. Dr. LUIZ CARLOS BASSO

Dissertação apresentada à Escola Superior de Agricultura "Luiz de Queiroz", da Universidade de São Paulo, para obtenção do título de Mestre em Ciências. Área de concentração: Ciência e Tecnologia de Alimentos.

PIRACICABA

Estado de São Paulo - Brasil

Agosto de 1996 


\section{Dados Internacionais de Catalogação na Publicação (CIP) DIVISÃO DE BIBLIOTECA E DOCUMENTAÇẪO - Campus “Luiz de Queiroz"/USP}

\section{Alcarde, André Ricardo}

Efeito da trealose na manutenção da viabilidade de células de leveduras desidratadas pelo processo de liofilização / André Ricardo Alcarde. - - Piracicaba , 1996.

92p. : il.

Dissertaçāo (mestrado) - - Escola Superior de Agricultura Luiz de Queiroz, 1996. Bibliografia.

1. Levedura - Célula - Conservação 2. Levedura - Liofilização 3. Trealose - Efeito I. Título

CDD 589.23 


\title{
EFEITO DA TREALOSE NA MANUTENÇÃO DA VIABILIDADE DE CÉLULAS DE LEVEDURAS DESIDRATADAS PELO PROCESSO DE LIOFILIZAÇÃO
}

\author{
ANDRÉ RICARDO ALCARDE
}

Aprovada em 08.10.1996

Comissão Julgadora Prof. Dr. Luiz Carlos Basso Prof. Dr. Jorge Horii ESALQ/USP Prof $f^{a}$. Dr ${ }^{\mathrm{a}}$. Lilliam Amorim

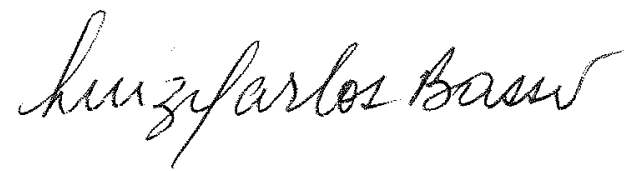
m

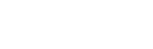

ESALQ/USP

ESALQ/USP 
À SARITA, pela dedicação demonstrada, compreensão e amor

Dedico 
Aos meus pais JOSE CARLOS e NTUZA 


\section{AGRADECIMENTOS}

A Deus, por ser o meu guia em todas as etapas da minha vida.

Agradeço a todos aqueles que de alguma forma contribuíram para a realização deste trabalho, especialmente:

Ao Prof. Dr. Luiz Carlos Basso, pela sabedoria na orientação, amizade e confiança constante ao longo deste trabalho.

Ȧ FERMENTEC S/C Ltda, Assitência Técnica em Fermentação Alcoólica, e em especial ao Prof. Dr. Henrique Vianna de Amorim, pela amizade e apoio financeiro às pesquisas.

À Coordenação de Aperfeiçoamento de Pessoal de Nível Superior, pela concessão da bolsa de estudo.

À Escola Superior de Agricultura "Luiz de Queiroz", de modo particular ao Departamento de Ciência e Tecnologia Agroindustrial a ao Departamento de Química, seus professores e funcionários, pelas facilidades para a execução deste trabalho.

À Prof ${ }^{a}$. Dr ${ }^{\mathrm{a}}$. Sônia Maria Stefano Piedade, pelas análises estatísticas dos resultados.

Ao meu irmão Valmir Eduardo Alcarde, pelos auxilios prestados.

Aos amigos Admir de Almeida Campos e Nancy de Campos Amaral, pela convivência e colaboração. 


\section{SUMÁRIO}

Página

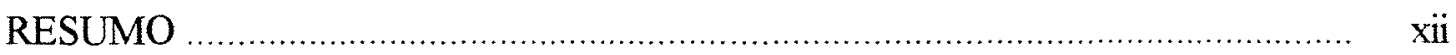

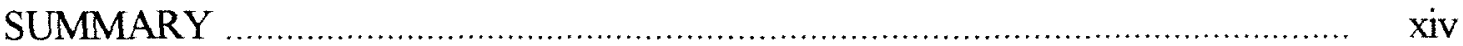

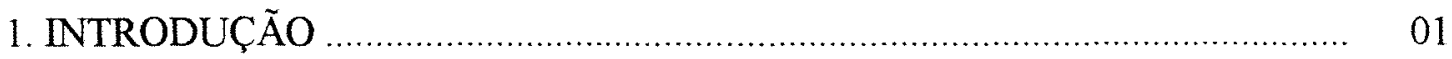

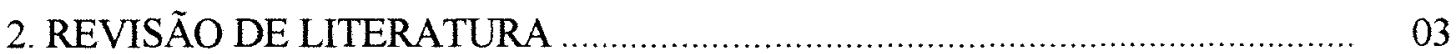

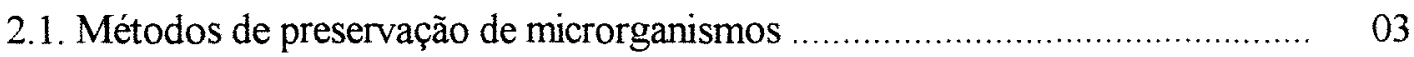

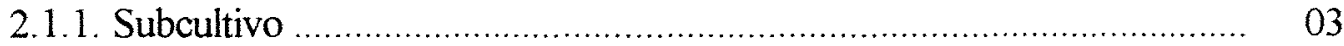

2.1.2. Secagem ou desidratação ........................................................ 04

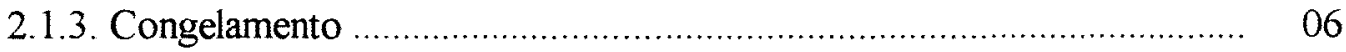

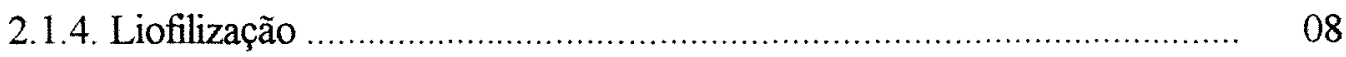

2.2. Adaptação dos microrganismos a agentes estressantes .............................. 12

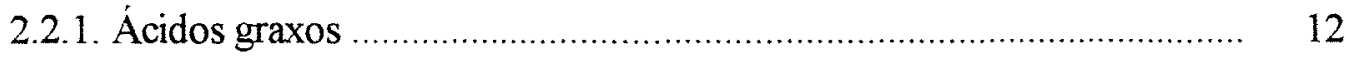

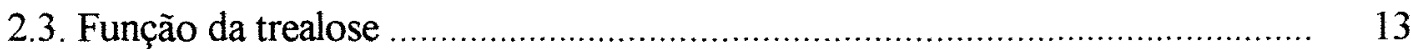

2.4. Acúmulo de trealose em microrganismos ............................................. 15

2.4.1. Fatores que afetam o acúmulo de trealose ....................................... 19

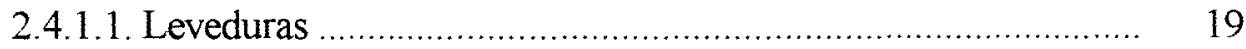

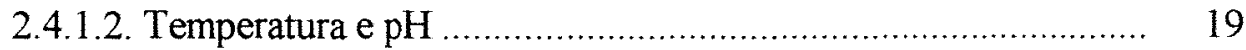

2.4.1.3. Concentração de açúcar ................................................. 20

2.4.1.4. Fontes de nitrogênio ................................................ 21

2.4.1.5. Inibidores ................................................................ 22

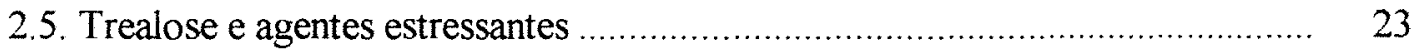

2.5.1. Trealose e termotolerância .................................................... 24

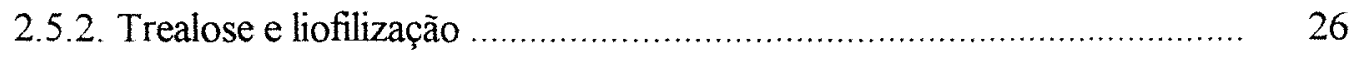

2.5.3. Trealose e tolerância ao etanol ..................................................... 27

2.5.4. Trealose e osmotolerância ...................................................... 27 


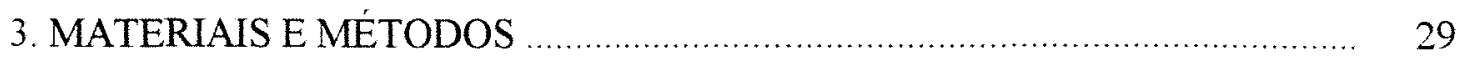

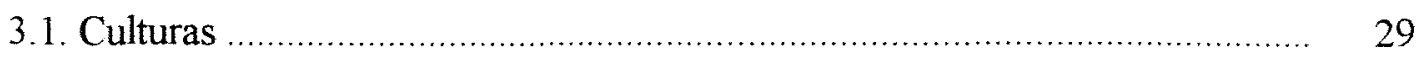

3.2. Meio de cultivo para a reativação das culturas de levedura ............................. 30

3.3. Manutenção das culturas de levedura .................................................... 30

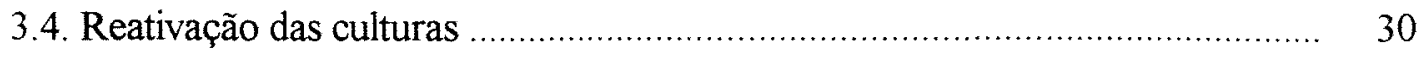

3.5. Multiplicação das leveduras reativadas ..................................................... 31

3.6. Meio de fermentação para o acúmulo da trealose endógena ........................... 31

3.7. Teste para verificar o acúmulo e a degradação da trealose endógena pelas

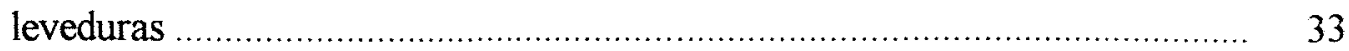

3.8. Acúmulo e esgotamento da trealose endógena ........................................... 35

3.9. Avaliação da influência da trealose na manutenção da viabilidade de células de leveduras submetidas ao processo de liofilização ............................................ 35

3.10. Procedimentos para a liofilização ……………...................................... 38

3.10.1. Preparo das ampolas ................................................................... 38

3.10.2. Preparo do inóculo ................................................................... 38

3.10.3. Teste para verificação de vácuo ........................................................... 38

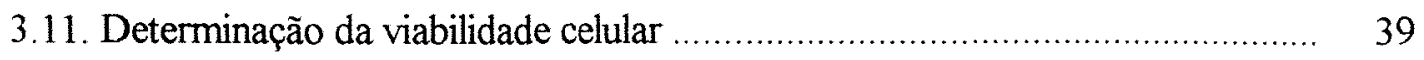

3.12. Determinação da trealose endógena .......................................................... 39

3.13. Delineamento experimental e análise estatística dos dados ........................... 40

3.14. Padronização das Tabelas e Figuras ........................................................ 40

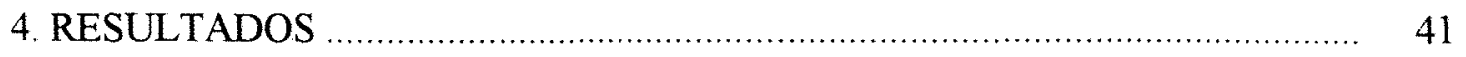

4.1. Teste para verificar o acúmulo e a degradação da trealose endógena pelas

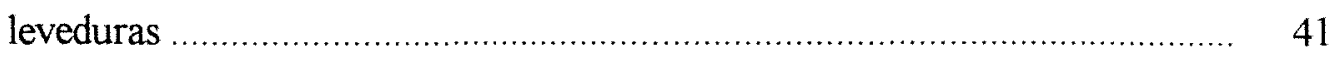

4.2. Efeito dos tratamentos na viabilidade das leveduras e na sua manutenção após liofilização .

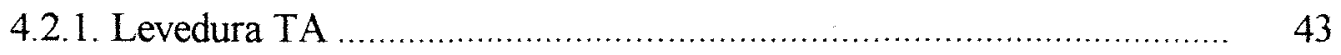

4.2.2. Levedura IZ-1904 ............................................................. 47

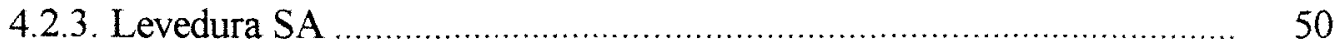

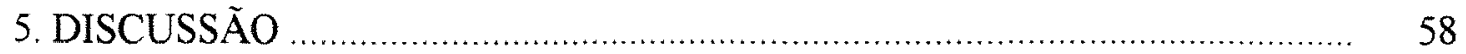


6. CONCLUSÕES

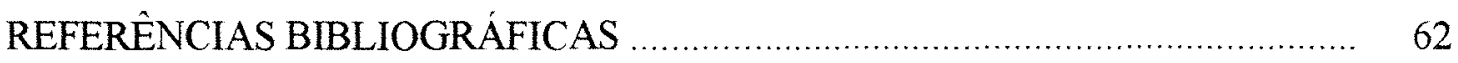

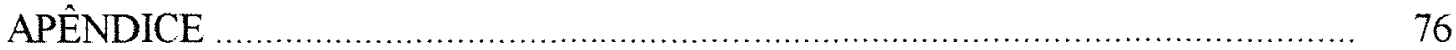




\section{LISTA DE FIGURAS}

FIGURA №

Página

01 Biossintese e degradação da trealose

02 Esquema para reativação e multiplicação das culturas de levedura

03 Esquema do teste para verificar o acúmulo e a degradação da trealose endógena das leveduras

04 Esquema para avaliação da influência da trealose na manutenção da viabilidade celular de leveduras submetidas ao processo de liofilização

05 Acúmulo e degradação da trealose endógena das leveduras em função do tempo de fermentação

06 Efeito dos tratamentos no comportamento da viabilidade da levedura TA após liofilização

07 Efeito dos tratamentos na manutenção da viabilidade da levedura TA após liofilização

08 Efeito dos tratamentos no comportamento da viabilidade da levedura IZ-1904 após liofilização

09 Efeito dos tratamentos na manutenção da viabilidade da levedura IZ-1904 após liofilização 
10 Efeito dos tratamentos no comportamento da viabilidade da levedura SA após liofilização

11 Efeito dos tratamentos na manutenção da viabilidade da levedura SA após liofilização

12 Efeito do tratamento esgotamento da trealose endógena, tendo a solução de leite desnatado como crioprotetor para a liofilização, na manutenção da viabilidade das leveduras após liofilização

13 Efeito do tratamento esgotamento da trealose endógena, tendo a solução de sacarose como crioprotetor para a liofilização, na manutenção da viabilidade das leveduras após liofilização

14 Efeito do tratamento esgotamento da trealose endógena, tendo a solução de trealose como crioprotetor para a liofilização, na manutenção da viabilidade das leveduras após liofilização

15 Efeito do tratamento acúmulo da trealose endógena, tendo a solução de leite desnatado como crioprotetor para a liofilização, na manutenção da viabilidade das leveduras após liofilização

16 Efeito do tratamento acúmulo da trealose endógena, tendo a solução de sacarose como crioprotetor para a liofilização, na manutenção da viabilidade das leveduras após liofilização

17 Efeito do tratamento acúmulo da trealose endógena, tendo a solução de trealose como crioprotetor para a liofilização, na manutenção da viabilidade das leveduras após liofilização 


\section{LISTA DE TABELAS}

TABELA №

Página

01 Ação dos diferentes tratamentos testados sobre a manutenção da viabilidade celular aos 10, 40 e 90 dias após a liofilização das leveduras utilizadas 


\section{APÊNDICE}

TABELA №

Página

01 Acúmulo e degradação da trealose endógena pelas leveduras em função do tempo de fermentação

02 Efeito dos tratamentos no teor da trealose endógena da levedura TA, na sua viabilidade inicial e aos 10, 40 e 90 dias após liofilização

03 Efeito dos tratamentos na manutenção da viabilidade pela levedura TA aos 10,40 e 90 dias após liofilização

04 Efeito dos tratamentos no teor da trealose endógena da levedura IZ-1904, na sua viabilidade inicial e aos 10,40 e 90 dias após liofilização

05 Efeito dos tratamentos na manutenção da viabilidade pela levedura IZ-1904 aos 10, 40 e 90 dias após liofilização

06 Efeito dos tratamentos no teor da trealose endógena da levedura SA, na sua viabilidade inicial e aos 10, 40 e 90 dias após liofilização

07 Efeito dos tratamentos na manutenção da viabilidade pela levedura SA aos 10, 40 e 90 dias após liofilização

08 Análise da variância para o efeito acúmulo da trealose endógena pela levedura TA 
09 Análise da variância para o efeito manutenção da viabilidade celular pela levedura TA aos 10 dias após liofilização

10 Análise da variância para o efeito manutenção da viabilidade celular pela levedura TA aos 10,40 e 90 dias após liofilização

11 Análise da variância para o efeito acúmulo da trealose endógena pela levedura IZ-1904

12 Análise da variância para o efeito manutenção da viabilidade celular pela levedura IZ-1904 aos 10 dias após liofilização

13 Análise da variância para o efeito manutenção da viabilidade celular pela levedura IZ-1904 aos 10, 40 e 90 dias após liofilização

14 Análise da variância para o efeito acúmulo da trealose endógena pela levedura SA.

15 Análise da variância para o efeito manutenção da viabilidade celular pela levedura SA aos 10 dias após liofilização

16 Análise da variància para o efeito manutenção da viabilidade celular pela levedura SA aos 10, 40 e 90 dias após liofilização

17 Análise da variância para o efeito acúmulo da trealose endógena pelas leveduras

18 Análise da variância para o efeito manutenção da viabilidade celular pelas leveduras aos 10 dias após liofilização 


\title{
EFEITO DA TREALOSE NA MANUTENÇÃO DA VIABILIDADE DE CÉLULAS DE LEVEDURAS DESIDRATADAS PELO PROCESSO DE LIOFILIZAÇÃO
}

\author{
Autor: André Ricardo Alcarde \\ Orientador: Prof. Dr. Luiz Carlos Basso
}

\section{RESUMO}

Os métodos de preservação têm como objetivo manter a viabilidade e estabilidade dos organismos por longo tempo, através da paralisação ou retardamento do seu metabolismo celular.

A liofilização é um método de preservação de microrganismos que consiste na remoção do vapor de água diretamente de amostras congeladas e continuada secagem sob vácuo, até produção de material estável. É considerado um dos mais efetivos métodos de preservação, pois mantém um maior índice de sobrevivência e maior estabilidade dos microrganismos.

A trealose é um dissacarídeo não redutor constituido de duas unidades de glucose. A trealose, mais que um carboidrato de reserva, é um protetor contra condições de estresse fisiológico, tais como extremos de temperatura, choque osmótico, efeitos tóxicos do etanol, dessecação e desidratação. Outra função da trealose é a de manter a viabilidade celular durante o periodo de armazenamento das leveduras.

A trealose age de modo a proteger a membrana plasmática durante a desidratação, substituindo a molécula de água que está ligada às cabeças polares dos fosfolipídios, mantendo assim a integridade, fluidez e permeabilidade da membrana e consequentemente a viabilidade celular. 
O acúmulo de trealose ocorre com estímulo de um agente estressante, dependendo do tempo de exposição.

O presente trabalho teve como objetivo verificar a influência da trealose endógena e também o uso da trealose como crioprotetor na manutenção da viabilidade celular de leveduras de interesse industrial, durante o processo de liofilização.

Foram utilizadas três cepas da levedura Saccharomyces cerevisiae: TA, IZ-1904 e $\mathrm{SA}$, as quais são conhecidas por exibirem performances fermentativas diferenciadas e apresentarem diferentes tolerâncias aos diversos agentes estressantes da fermentação. As leveduras passaram por um tratamento de acúmulo da trealose endógena, através de fermentação a $45^{\circ} \mathrm{C}$ por duas horas em meio tampão citrato de potássio $2 \mathrm{M}, \mathrm{pH} 4,0$, acrescido de $2 \%$ de glicose. Após o tratamento foram retiradas amostras para se determinar o teor de trealose endógena das leveduras, bem como sua viabilidade, $e$, a seguir, as leveduras foram ressuspensas em três crioprotetores, que foram: solução de leite desnatado a $10 \%$, solução de sacarose a $10 \%$ e solução de trealose a $10 \%$. Em seguida as massas de levedura remanescentes foram liofilizadas e, aos 10,40 e 90 dias após a liofilização, foram-se determinadas suas viabilidades.

A análise estatística dos dados mostrou um efeito significativo $(p \leq 0,01)$ no acúmulo de trealose endógena e na manutenção da viabilidade celular após liofilização para todas as leveduras testadas.

Para todos os crioprotetores, as culturas de levedura que passaram pelo tratamento de acúmulo da trealose endógena apresentaram maior viabilidade após a liofilização que aquelas que não passaram pelo tratamento.

Dentre os crioprotetores testados, a solução de leite desnatado a $10 \%$ foi o que proporcionou melhor crioproteção às células de levedura.

Dos tratamentos testados, o que manteve maior taxa de viabilidade celular nas leveduras após a liofilização foi o de acúmulo da trealose endógena, tendo como crioprotetor para as células de levedura a solução de leite desnatado a $10 \%$, podendo este tratamento ser utilizado para uma melhor preservação de leveduras. 


\title{
EFFECT OF TREHALOSE ON THE VIABILITY MAINTENANCE OF YEASTS CELLS DEHYDRATED BY FREEZE-DRYING PROCESS
}

\author{
Candidate: André Ricardo Alcarde \\ Adviser: Prof. Dr. Luiz Carlos Basso
}

\section{SUMMARY}

The purpose of the methods for microorganism preservation is to maintain their viability and stability for a long time, through the paralisation or retardation of their cellular metabolism.

The freeze-drying process is based on the removal of water vapour straight from frozen samples and continuous drying under vacuum until production of a stable material. It is one of the most effective methods of microorganism preservation because it maintains higher survival and stability rates.

Trehalose is a non-reducting disaccharide of glucose mainly found in yeasts. Trehalose, more than a storage carbohydrate, has carried out a protective role under stress conditions such as heat stress, osmotic shock, ethanol harmful effects, drying and dehydration. Trehalose also maintains the yeast cells viability during the storage period.

During dehydration, trehalose protects the plasmatic membrane replacing the molecule of water which is linked to the polar heads of the phospholipids, so maintaining the membrane integrity, fluidity and permeability and consequently the cellular viability.

Yeast cells accumulate trehalose in response to certain stress conditions, depending on the time of exposure. 
Basing in the assumptions, this work was undertaken to evaluate the influence of the endogenous trehalose and also the use of trehalose in a cryoprotectant medium on the yeast cells viability maintenance after freeze-drying process.

The yeasts Saccharomyces cerevisiae (TA), Saccharomyces cerevisiae (IZ-1904) and Saccharomyces cerevisiae (SA), which exhibit great differences in respect to their fermentation capabilities and tolerance to several stressing conditions, were tested. After accumulation of endogenous trehalose by heat treatment at $45^{\circ} \mathrm{C}$ by 2 hours in potassium citrate buffer $2 \mathrm{M} \mathrm{pH} 4,0$ with $2,0 \%$ glucose in the same buffer, samples were taken for determinations of trehalose and yeast cell viability.

Thereafter the yeast suspensions were ressuspended in one of three cryoprotectants solutions (skimmed milk 10\%, saccharose $10 \%$ and trehalose $10 \%$ ), freeze-dryed and analised for their cell viability after 10,40 and 90 days storage.

The statistical treatment of data showed a significative effect $(p \leq 0,01)$ on the endogenous trehalose accumulation and on the viability maintenance after the freeze-drying process for all yeasts tested.

Higher viability maintenance after the freeze-drying process occured for all yeasts at the higher endogenous trehalose levels.

The solution of skimmed milk $10 \%$ was the better cryoprotectant medium to the yeast cells.

The most effective treatment for viability maintenance after the freeze-drying process was endogenous trehalose accumulation with solution of skimmed milk $10 \%$ as a cryoprotectant medium to the yeast cells, pointing out that it could be a usefull treatment for better yeasts preservation. 


\section{INTRODUÇÃO}

As leveduras são os microrganismos mais utilizados para a produção industrial de álcool, cerveja e pão. Estes microrganismos fermentam substratos açucarados, convertendoos em etanol e dióxido de carbono, através da fermentação alcoólica.

A preocupação com a manutenção de culturas viáveis iniciou simultaneamente à descoberta dos meios artificiais de cultivo, pois a disponibilidade de microrganismos sempre foi considerada essencial ao desenvolvimento da Microbiologia, quer no setor industrial, acadêmico ou científico-tecnológico.

O reconhecimento desta necessidade e o desenvolvimento das técnicas de conservação deram origem à formação das coleções de culturas, hoje existentes em todo o mundo, oferecendo um número diversificado de serviços (Kirsop, 1984).

Os métodos de preservação têm como objetivo manter a viabilidade e a estabilidade dos organismos. Para obter esta situação, por longo tempo, é necessário a paralisação ou o retardamento do metabolismo celular. Para tal, inúmeros processos são utilizados e constituem-se nos métodos de conservação, ou seja, o sub-cultivo ou repiques sucessivos, a secagem ou desidratação, o congelamento e a liofilização. A seleção destes métodos tem

como finalidade produzir maior índice de sobrevivência e maior estabilidade dos microrganismos.

A trealose é um dissacarídeo não redutor constituido de duas unidades de glicose. Este carboidrato foi inicialmente isolado do fungo causador da ferrugem do centeio, sendo extraído pela primeira vez de células de levedura em 1925 por Kock \& Kock. A trealose, segundo Thevelein (1984), parece servir principalmente como carboidrato de reserva durante 
os períodos de não proliferação celular, porém atualmente acredita-se que a trealose desempenhe uma função de proteção contra condições de estresse fisiológico.

Suomalainen \& Pfaffli (1961) atribuem à trealose a função de manter a viabilidade celular durante o armazenamento de leveduras de panificação e Lillie \& Pringle (1980) associaram a sobrevivência de células de levedura por períodos prolongados de tempo principalmente ao nivel de trealose. Contudo, Wilson \& Mcleod (1976) citam que a perda de viabilidade durante $o$ armazenamento de leveduras se deve à deficiência de reservas endógenas e sim à alteração na função das membranas, causada por falta de esteróis e ácidos graxos insaturados.

Panek et alii (1987) citam que a trealose pode representar um papel importante na preservação da integridade da membrana celular, o que de certa forma poderia justificar a existência de dois carboidratos de reserva para a levedura, a trealose e o glicogênio.

$\mathrm{O}$ presente trabalho teve por objetivo avaliar a influência da trealose endógena, $\mathrm{e}$ também o uso da trealose como crioprotetor, na preservação da viabilidade celular de leveduras de interesse industrial submetidas ao processo de liofilização, contribuindo com informações que poderão auxiliar numa melhor preservação de células de leveduras. 


\section{REVISÃO DE LITERATURA}

\subsection{Métodos de preservação de microrganismos}

\subsubsection{Subcultivo}

$\mathrm{O}$ método consiste na inoculação de microrganismos em meio adequado, com incubação para obtenção de crescimento e estocagem sob determinadas condições, com repicagens para meio apropriado em intervalos de tempo (Kirsop, 1984).

O intervalo de tempo entre os sub-cultivos, segundo este mesmo autor, varia com o microrganismo e com os seguintes parâmetros:

a) meio de cultivo: deve-se dar preferência por meios pobres em nutrientes porque proporcionam baixo metabolismo e assim prolonga-se o intervalo entre as repicagens. Deve-se também evitar excesso de carboidratos metabolizáveis, que produziriam ácidos que poderiam inviabilizar a cultura. Alguns microrganismos, entretanto, requerem meios complexos de crescimento, como por exemplo as bactérias láticas dos gêneros Neisseria, Leptospira, Kloeckera e Honseniaspora, as quais exigem maior freqüência nas transferências como resultado do crescimento acelerado e acúmulo de produtos indesejáveis.

b) temperatura: pode-se utilizar temperatura ambiente na incubação, porém é necessário monitoração e cuidados para evitar a desidratação. $\mathrm{O}$ armazenamento sob refrigeração ( 5 a $8^{\circ} \mathrm{C}$ ) confere redução no metabolismo, aumentando o intervalo entre repiques. 
c) tempo de transferência: deve ser estabelecido de acordo com as condições ótimas e tempo máximo de sobrevivência para as diferentes cepas microbianas.

Este é um método vantajoso pelo baixo custo, pelo uso de técnicas simples, pela ausência de estresse celular e por não exigir equipamentos sofisticados. Entretanto, é desvantajoso devido às possiveis mudanças metabólicas, maior risco de contaminação, perda de características genéticas, necessidade de maior espaço fisico e por ser trabalhoso, se o microrganismo necessitar repiques em curto espaço de tempo (Kirsop, 1984).

As culturas de microrganismos podem ser mantidas em ágar sob óleo mineral durante a estocagem. Isto reduz a disponibilidade de ar, diminuindo o metabolismo celular e a desidratação, sendo utilizado principalmente para fungos (Guerna, 1981).

Outra variação do método, segundo Costa \& Ferreira (1991), constitui-se no chamado blocos de ágar sob água, que inocula o microrganismo em ágar apropriado, sendo que após crescimento vigoroso deve ser cortado em blocos e alguns cubos transferidos assepticamente para tubos contendo água esterilizada e assim estocados. Sua aplicação está restrita a microrganismos que tenham grande aderência ao ágar, como fungos e algumas leveduras.

Por último, o uso de água esterilizada, onde se deposita a massa celular para estocagem, tem sido proposto para bactérias fitopatógenas, esporos de Bacillus, vírus da hepatite e poliovírus (Leaper \& Bloor, 1988).

\subsubsection{Secagem ou desidratação}

A maioria das células vivas possui $80 \%$ de água, e esta fase líquida é essencial para a atividade biológica. O metabolismo celular é reduzido quando se restringe a atividade de água (Kirsop, 1984).

Esta técnica é recomendada para fungos e bactérias esporuladas, os quais são mais resistentes à desidratação (Kirsop, 1984). 
Grivell \& Jackson (1969) citam que várias matrizes podem ser empregadas, e dentre elas as mais comuns são areia, solo ou sílica gel. Faz-se a suspensão do microrganismo em água esterilizada, quando a matriz for solo ou areia, e em leite desnatado gelado a $5 \%$ quando for sílica. Inocula-se na matriz e deixa-se secar à temperatura ambiente por alguns dias. Quando secos (grânulos soltos), veda-se o frasco e estoca-se. Para reativação, alguns grânulos são inoculados diretamente sobre o meio indicado.

Segundo Antheunisse et alii (1981) tiras de papel são utilizáveis também como matrizes. Recomenda-se papel de filtro Whatman $n^{\circ} 4$, previamente cortado e autoclavado em folha de alumínio, onde inocula-se a suspensão microbiana, que em dessecador por algumas semanas a $4^{\circ} \mathrm{C}$, é desidratada. Após este periodo, o material é selado e armazenado em recipientes secos. Para reativação, uma tira ou disco é retirado assepticamente e inoculado em meio adequado.

Pode-se ainda preparar pastilhas de amido, peptona ou dextrana, onde inocula-se um volume da suspensão celular. As pastilhas são secas e armazenadas sob vácuo. Preserva-se com sucesso bactérias que não sobrevivem satisfatoriamente à liofilização como Neisseria gonorrhoeae e Vibrio cholerae (Costa \& Ferreira, 1991).

Sinclair \& Alexander (1984) citam que outro suporte utilizado é o disco de gelatina. Prepara-se uma suspensão microbiana em meio de gelatina nutriente, distribui-se gotas desta suspensão em placas de Petri esterilizadas, que são levadas a secar. Os discos obtidos são armazenados em recipientes contendo sílica gel ou pentóxido de fósforo. $O$ método é extremamente simples, econômico, não demanda aparelhos sofisticados, facilita o trabalho de postagem de grande número de culturas e apresenta baixo risco de contaminação. Entretanto, a viabilidade celular pode ser comprometida se a cultura for armazenada por longo tempo (Costa \& Ferreira, 1991).

Coutinho et alii (1988), estudando o efeito protetor da trealose endógena na preservação de células de levedura, citam que culturas de levedura secas a $37^{\circ} \mathrm{C}$ por 6 horas mantiveram a viabilidade durante o periodo de secagem, porém perderam viabilidade drasticamente quando armazenadas a $5^{\circ} \mathrm{C}$ por 48 horas após a secagem. No entanto, uma 
cepa que continha um alto teor de trealose endógena em suas células conseguiu manter a sua viabilidade durante o citado armazenamento após secagem.

Comparando três temperaturas de secagem de células de levedura Saccharomyces cerevisiae, Dalaly \& Tawfeeq (1987) concluiram que a melhor temperatura, sob o ponto de vista de atividade e de viabilidade das células após secagem, foi a de $50^{\circ} \mathrm{C}$, seguida pela de $60^{\circ} \mathrm{C}$ e $40^{\circ} \mathrm{C}$, respectivamente. $\mathrm{O}$ conteúdo de carboidratos totais e o de trealose em amostras secas a $50^{\circ} \mathrm{C}$ foram maiores que a $60^{\circ} \mathrm{C}$ e a $40^{\circ} \mathrm{C}$. Por isso os autores acreditam que os teores de carboidratos totais, trealose, nitrogênio total e proteínas em leveduras secas têm efeito na sua atividade e viabilidade após secagem.

\subsubsection{Congelamento}

O congelamento das amostras microbianas e a estocagem a baixas temperaturas permitem um bloqueio seguro no metabolismo celular (Guerna, 1981). Porém, congelamento e descongelamento acarretam danos celulares, que se manifestam por vários níveis de alterações. Esta crio-injúria, segundo Costa e Ferreira (1991), pode ser resultante de choque térmico, do efeito da concentração de soluto intra e extra-celular, da desidratação, da formação de gelo interno e da não manutenção de um volume mínimo de célula.

O congelamento pode ser praticado em freezer (valor de abaixamento de temperatura por minuto $=1^{\circ} \mathrm{C}$ ), com gelo seco, em nitrogênio líquido e a estocagem pode variar de $-20^{\circ} \mathrm{C}$ a $-196^{\circ} \mathrm{C}$ (Costa \& Ferreira, 1991).

Ludlam et alii (1989) citam que a estocagem a $-70^{\circ} \mathrm{C}$ tem sido utilizada com sucesso para diferentes microrganismos, como bactérias, micoplasmas, fungos e protozoários.

A crio-preservação em nitrogênio líquido $\left(-196^{\circ} \mathrm{C}\right)$ ou nitrogênio em fase de vapor $\left(-150^{\circ} \mathrm{C}\right)$ é universalmente aplicada aos fungos, vírus, algas, protozoários, leveduras, células de mamíferos, células vegetais e bactérias (Wellman \& Stewart, 1973).

Kratochvilová \& Hubálek (1983) verificaram a estabilidade de leveduras conservadas em nitrogênio líquido, comparando-a com linhagens equivalentes preservadas sob óleo mineral e concluiram que após 5 anos todas as características qualitativas testadas das 
leveduras permaneceram estáveis em ambos os métodos de conservação, embora a viabilidade celular das leveduras mantidas em nitrogênio líquido tenha variado entre 5 e $97 \%$.

Kirsop (1984) cita que leveduras preservadas em nitrogênio líquido mostram alta viabilidade, encontrando para o gênero Saccharomyces $65 \%$ em média, e para os gêneros Candida e Brettanomyces $73 \%$ e $64 \%$, respectivamente.

É um método rápido, fácil, não demanda manipulação durante a estocagem e não requer grande espaço. A estocagem quando feita em nitrogênio líquido, permite manter por longo tempo a viabilidade e é útil para microrganismos mais sensiveis. No entanto, o seu custo é elevado, além de exigir cuidados com o suprimento de nitrogênio, sendo limitado quanto à distribuição. Além disso, o nitrogênio líquido exige suprimento contínuo e apresenta riscos de explosão (Costa \& Ferreira, 1991).

Deve-se considerar também fatores como a velocidade de descongelamento, condições de crescimento e idade de cultivo (Mugnuier \& Jung, 1985).

Para proteção dos microrganismos utilizam-se agentes crio-protetores, como o glicerol a $10 \%$, o dimetilsulfóxido (DMSO) a $5 \%$, leite desnatado a $10 \%$, inositol a $10 \%$ e sacarose a 10\% (Meryman et alii, 1977 e Chavarri et alii, 1988).

Coutinho et alii (1988), estudando o efeito crioprotetor da trealose na preservação de células de levedura, citam que quando estas foram congeladas a $-120^{\circ} \mathrm{C}$, a adição de $10 \%$ de trealose apresentou um significante efeito crioprotetor, o mesmo não ocorrendo quando se utilizou este carboidrato na concentração de $5 \%$.

Gélinas et alii (1991) não observaram relação entre o conteúdo celular de lipídios e a criotolerância de células de leveduras Saccharomyces cerevisiae submetidas ao congelamento a $-50^{\circ} \mathrm{C}$.

Investigando o efeito crioprotetor de álcoois em Saccharomyces cerevisiae sob várias condições de congelamento, Lewis et alii (1994) observaram que, sob uma taxa de resfriamento de $3^{\circ} \mathrm{C}$ por minuto, metanol e etanol não desempenharam papel de crioproteção. Porém, a uma taxa de resfriamento de $200^{\circ} \mathrm{C}$ por minuto, metanol e etanol demonstraram crioproteção maior que a lactose, trealose, polietileno glicol, glicerol, dimetilsulfóxido e polivinil pirrolidona. Segundo os autores, uma taxa minima de resfriamento de $25^{\circ} \mathrm{C}$ por 
minuto é necessária para que o efeito de crioproteção do etanol seja observado. Os autores acreditam que o efeito crioprotetor de álcoois durante um rápido congelamento é resultado da sua habilidade em induzir o aumento da permeabilidade celular da membrana, permitindo assim um rápido equilibrio de água durante o congelamento extracelular e evitando a formação de cristais de gelo intracelulares.

Segundo Lewis et alii (1993) o etanol pode ter dois efeitos na crioproteção de leveduras Saccharomyces cerevisiae, como uma fonte de carbono respirável, conferindo às células grande tolerância ao congelamento, e como crioprotetor sob condições de congelamento rápido $\left(200^{\circ} \mathrm{C}\right.$ por minuto). Sob condições de congelamento lento $\left(3^{\circ} \mathrm{C}\right.$ por minuto) o glicerol agiu como crioprotetor enquanto que o etanol perdeu esta habilidade.

\subsubsection{Liofilização}

Consiste na remoção do vapor de água diretamente de amostras congeladas e continuada secagem sob vácuo, até produção de material estável (Kirsop, 1984; Chang \& Elander, 1986). É considerado um dos mais efetivos métodos de preservação para a maioria dos microrganismos, sendo entretanto menos aplicável para algas e inadequado para protozoários (Antheunisse, 1973; Alexander, 1981).

Heckly \& Quay (1981) citam que dentre as várias manifestações de dano celular causadas por este processo incluem-se as alterações na permeabilidade da membrana celular, o aumento da sensibilidade para alguns agentes seletivos, o aumento da fase lag de crescimento e a necessidade de incremento nutricional. Seu processamento é aparentemente simples, porém são muitos os fatores que interferem na técnica em si.

Segundo Ashwood-Smith et alii (1972), para preparar a suspensão microbiana, devese utilizar culturas no final da fase logarítmica e no início da estacionária, que correspondem ao máximo de crescimento e estabilidade, muito embora alguns microrganismos, como o Rhizobium meliloti, apresentem melhor sobrevivência quando liofilizados na fase logarítmica de crescimento. 
Deve ser levado em consideração o incremento no congelamento, uma vez que, realizado lentamente, leva à formação de poucos cristais de gelo grandes, enquanto o congelamento rápido forma inúmeros cristais pequenos. Não se pode esquecer, entretanto, que ocorre maior desidratação quando o decréscimo da temperatura é feito lentamente (Farrant et alii, 1977).

Berny \& Hennebert (1991) avaliaram os efeitos da velocidade de congelamento e meio protetor sobre a viabilidade e estabilidade de cepas de leveduras durante o processo de liofilização. Verificaram que a viabilidade de células de Saccharomyces cerevisiae foi de 96$98 \%$ quando foi utilizado um meio protetor contendo $10 \%$ de leite desnatado e mais dois dos seguintes componentes: mel ( 5 a $10 \%$ ), glutamato de sódio $(5 \%)$, trealose $(10 \%)$ ou rafinose (10\%). Quando este meio protetor não foi utilizado, a viabilidade reduziu-se para $30 \%$ após a liofilização. A velocidade de congelamento que proporcionou valores mais elevados de células viáveis foi de $3^{\circ} \mathrm{C}$ por minuto.

Silva et alii (1992a), estudando a influência da condição de cultivo, da velocidade de congelamento e do meio protetor na viabilidade celular de leveduras após liofilização, verificaram que as células crescidas em meio sólido apresentaram-se mais resistentes ao congelamento que aquelas crescidas em meio líquido sob agitação. Quanto à velocidade de congelamento, os melhores resultados de viabilidade após liofilização foram obtidos quando o congelamento lento ( $\mathrm{l}$ a $10^{\circ} \mathrm{C}$ por minuto) foi previamente empregado. $\mathrm{O}$ congelamento rápido (mais de $10^{\circ} \mathrm{C}$ por minuto) de células oriundas de culturas submersas agitadas causou grande perda na viabilidade após liofilização. Quanto aos crioprotetores, tanto o leite desnatado acrescido de $5 \%$ de glutamato de sódio quanto o soro de sangue de cavalo com $3,75 \%$ de glicose apresentaram resultados similares.

Segundo Kupleshaya (1987) é importante que haja uma alta concentração celular viável na ampola antes da liofilização, pois uma relativa perda de viabilidade pode ocorrer no processo, apesar destes mesmos microrganismos mortos servirem de proteção aos que permanecerem viáveis.

Valdez (1985) cita que a umidade residual também deve ser levada em consideração, uma vez que a insuficiente secagem causa um rápido decréscimo da viabilidade. Este 
conteúdo ótimo variará com a composição da suspensão celular, atmosfera de estocagem, espécie e estado físiológico do microrganismo.

Segundo o mesmo autor, a atmosfera de exposição do liófilo também influencia na viabilidade da amostra estocada por este método. As ampolas devem ser seladas sob vácuo para evitar a ação deletéria do oxigênio molecular e a influência negativa de radicais livres. A absorção de umidade ou a presença de oxigênio em contato com as culturas liofilizadas pode comprometer a eficiência do processo.

Deve-se dar preferência à estocagem a baixas temperaturas e sempre na ausência de luz para se evitar a quebra da estabilidade do liófilo (Costa \& Ferreira, 1991). Kirsop (1984) recomenda a estocagem das ampolas liofilizadas a $4^{\circ} \mathrm{C}$, uma vez que temperaturas elevadas degradam rapidamente o produto, ou seja, levam à perda da estabilidade do liófilo.

Por último, o teor nutricional, a osmolaridade e a temperatura do fluido de reconstituição são decisivos na recuperação da injúria celular (Costa \& Ferreira, 1991).

A liofilização apresenta a vantagem de permitir a estocagem por longo tempo, possui menor risco de contaminação e não requer manipulação adicional. Por outro lado, demanda um alto custo e possui pontos críticos já enunciados anteriormente (Costa \& Ferreira, 1991).

Uma variação deste método, denominada L-drying, consiste na secagem sem congelamento, e é utilizado para microrganismos que não resistem à sublimação (Kirsop, 1984).

Silva et alii (1992b) compararam métodos de preservação de leveduras utilizadas industrialmente na produção de etanol. Os métodos avaliados foram o subcultivo em meio de cultura sólido, a suspensão em água destilada, a liofilização e a criopreservação em nitrogênio líquido, sendo a viabilidade celular e a capacidade de produção de etanol determinadas inicialmente e após diferentes períodos de estocagem. De um modo geral, os métodos mantiveram o rendimento em etanol dentro de niveis satisfatórios durante o armazenamento para as diferentes linhagens de Saccharomyces estudadas. Com relação à viabilidade celular, o subcultivo permitiu recuperar células viáveis por 10 meses sem necessidade de renovação de estoques. A preservação em água destilada manteve células viáveis por um período de até 50 meses, apresentando entretanto pequeno decréscimo na sua viabilidade. Embora a liofilização 
tenha promovido alta taxa de morte, o nivel de viabilidade celular remanescente permaneceu estável durante o período de estocagem. Já a criopreservação manteve a viabilidade em níveis elevados, apresentando vantagem neste aspecto sobre os demais métodos.

Kirsop (1984) cita que a média de viabilidade das leveduras liofilizadas e que fazem parte da "National Collection of Yeast Cultures" é de 5\% para o gênero Saccharomyces, $13 \%$ para o gênero Candida e $2 \%$ para Brettanomyces. Os gêneros para os quais o nivel de sobrevivência tem sido particularmente baixo são: Brettanomyces, Dekkera, Bullera, Sporobolomyces, Leucosporidium e Rhodosporidium.

Além dos agentes crioprotetores citados no método de congelamento, muitos outros são indicados com sucesso para a liofilização, como o etileno glicol a $10 \%$, o mel a 5 ou $10 \%$, o sangue de cavalo a $10 \%$ e a rafinose a 5 ou $10 \%$ (Benedict et alii, 1961). Segundo Yoshikawa et alii (1994) a trealose também é um agente de crioproteção para leveduras submetidas à conservação por liofilização.

Sidyakina et alii (1987) citam que a viabilidade de culturas de leveduras imediatamente após terminado o processo de liofilização variou de 4 a $33 \%$. Os meios protetores utilizados foram: SGA ( $10 \%$ sacarose, $1,5 \%$ de gelatina, $0,1 \%$ de agar), GDI ( $2 \%$ de glutamato de sódio, $5 \%$ de dextrana, $7,5 \%$ de inositol, $\mathrm{pH} 7.0$ ) e solução de sacarose a $12 \%$. Os autores demonstraram que a liofilização e a criopreservação em nitrogênio líquido podem ser usadas com sucesso para armazenar leveduras por longo tempo, sem comprometer suas propriedades bioquímicas essenciais. No entanto, a criopreservação apresenta maiores vantagens sobre a liofilização uma vez que mantém a viabilidade celular mais elevada por um período de tempo mais prolongado durante o armazenamento. $\mathrm{O}$ sistema de preservação mais indicado para as leveduras estudadas foi o de congelamento lento $\left(1^{\circ} \mathrm{C}\right.$ por minuto) numa solução a $20 \%$ de glicerol.

Para proporcionar uma maior e mais rápida recuperação de microrganismos liofilizados, Malik (1992) recomenda ressuspender as células no meio de cultivo líquido mais favorável para seu desenvolvimento, devendo sua incubação ser realizada abaixo da temperatura ótima para seu desenvolvimento. Além disso, a presença de carvão mineral ativado no meio de suspensão das células proporciona maiores índices de sobrevivência e 
culturas reativadas na presença deste material são mais estáveis e podem ser mantidas viáveis por longo tempo.

\subsection{Adaptação dos microrganismos a agentes estressantes}

Os microrganismos possuem a capacidade de se adaptarem a condições ambientais desfavoráveis ao seu desenvolvimento, tais como temperatura, desidratação, concentração de etanol no meio, concentração de açúcares dissolvidos no meio e outros agentes que provocam estresse às suas células.

Para que os microrganismos se adaptem a estas situações, eles criam mecanismos protetores como o acúmulo de trealose, que é um carboidrato de proteção ao estresse (Thevelein, 1984; Hottinger et alii, 1987a,b; Panek et alii, 1990), e alteração da composição de ácidos graxos da sua membrana citoplasmática.

\subsection{1. Ácidos graxos}

Segundo Suutari et alii (1990) os ácidos graxos influenciam as propriedades físicoquímicas dos lipídios da membrana citoplasmática, propriedades estas que, segundo Arthur \& Watson (1976), são de fundamental importància para o desenvolvimento dos microrganismos a diferentes temperaturas.

Wilson \& Mcleod (1976) atribuem a perda de viabilidade durante o armazenamento de leveduras a uma alteração na função das membranas, causada pela falta de esteróis e ácidos graxos insaturados, e não devido a uma deficiência de reservas endógenas.

Segundo Farrell \& Rose (1967) a temperatura condiciona a composição lipídica da membrana das leveduras. Para Brown \& Rose (1969), além da temperatura, também a espécie do microrganismo, a idade da cultura e a composição do meio de cultivo causam variação na composição em ácidos graxos dos microrganismos. 
Trabalho realizado por Alterthum \& Cruz (1987) concluiu que, sob temperaturas elevadas, predominam nos microrganismos ácidos graxos saturados e de cadeia longa, e sob temperaturas baixas, a insaturação aumenta e a cadeia carbônica diminui.

Segundo Low \& Parks (1987) o aumento da temperatura do meio ocasiona um aumento no conteúdo de ácidos graxos saturados e uma diminuição no conteúdo de insaturados em Saccharomyces cerevisiae.

Em trabalho realizado por Suutari et alii (1990) a alteração da temperatura causou alteração no tamanho da cadeia de ácidos graxos em Saccharomyces cerevisiae, no entanto, o aumento da temperatura não alterou a insaturação da cadeia, o que também foi observado por Hunter \& Rose (1972).

Segundo Mishra \& Prasad (1989) as células alteram sua composição de ácidos graxos quando submetidas a altas temperaturas e também em presença de etanol. Esses autores verificaram ainda que os ácidos graxos polinsaturados conferem às células de Saccharomyces cerevisiae maior tolerância ao etanol que os ácidos graxos monoinsaturados.

Quando as células de Saccharomyces cerevisiae são expostas ao etanol em condições estressantes, ocorre uma reestruturação lipídica da sua membrana (Sajbidor \& Grego, 1992).

\subsection{Função da trealose}

A trealose é um dissacarídeo não redutor formado por duas unidades de glicose com ligação no carbono anomérico. É um importante composto de armazenamento de células vegetativas e esporos de fungos além do glicogênio (Gutierrez, 1994).

Originalmente, a trealose, juntamente com o glicogênio, eram conhecidos como substâncias de reserva energética para a levedura, porém, recentemente, vários autores sugerem que a trealose possua função de proteção para a célula de levedura durante processos de estresse.

Thevelein (1984) cita que a trealose é um carboidrato de reserva que também teria a função de proteção em esporos de levedura, protegendo-os contra frio, calor e desidratação. 
Durante o processo de germinação, a trealose é rapidamente consumida. A função da trealose em esporos de levedura, segundo Barton et alii (1982), seria de suprimento de energia.

No entanto, Donnini et alii (1988) citam que a trealose fornece energia durante a dormência e não durante o processo de germinação dos esporos de Saccharomyces cerevisiae, pois estes autores verificaram que não houve nenhuma degradação de trealose durante a germinação de ascosporos de Saccharomyces cerevisiae.

Suomalainen \& Pfaffli (1961), trabalhando com levedura de panificação, verificaram que a manutenção da viabilidade celular era devida ao elevado teor de trealose. Neste caso a trealose teria a função de proteger as células contra a autólise.

A trealose pode representar um papel importante na preservação da integridade da membrana celular, o que poderia justificar a existência de dois carboidratos de reserva, a trealose e o glicogênio (Panek et alii 1987). Além disso, o aumento da resistência à pressão osmótica foi acompanhada pelo acúmulo de trealose, segundo Mackenzie et alii (1988).

Wienken (1990) concluiu que a função da trealose é a de proteção dos componentes do citosol da célula às condições adversas. Este autor cita que os organismos anidrobióticos possuem a capacidade de viver muito tempo no estado de desidratação, sendo resistentes a seca, calor e frio. Crowe et alii (1984a) verificaram que grande quantidade de trealose é encontrada nestes organismos.

Há modelos que explicam o efeito da proteção da trealose na membrana da célula de levedura durante os processos de desidratação-hidratação e congelamento-descongelamento. O modelo mais aceito é o proposto por Crowe et alii (1984b), pelo qual a trealose interage com os grupos polares das cadeias fosfolipídicas existentes na membrana. A trealose substituiria a água que está ligada às cabeças polares dos fosfolipídios quando em condições favoráveis e seria perdida no processo de estresse. Com a ligação da trealose à membrana não há alteração do espaçamento entre os fosfolipídios, evitando assim as separações laterais dos componentes da membrana. Com a substituição das moléculas de água pela trealose não há passagem da fase fluida para a fase gel da membrana, mantendo-se a integridade e fluidez da membrana e assim a viabilidade celular. O mesmo modelo foi defendido por Panek et alii (1993). 
D'amore et alii (1991) verificaram que as células de leveduras que produziam quantidades mais elevadas de etanol, a partir de um substrato com alta concentração de glicose, possuiam mais altas concentrações iniciais de trealose e mantinham-se mais viáveis quando estocadas a baixas temperaturas. Os autores concluíram que, para aumentar o desempenho fermentativo de leveduras, é necessário obter leveduras com alta quantidade de trealose.

Segundo Panek et alii (1993), devido ao papel de proteção da trealose contra altas temperaturas, choque osmótico, efeitos tóxicos do etanol, dessecação e desidratação, tem-se considerado atualmente a trealose como um protetor da membrana celular e suas proteínas, ficando o glicogênio como o principal carboidrato de reserva em leveduras.

Atualmente, destaca-se a participação da trealose na manutenção da viabilidade das células de leveduras quando as mesmas são submetidas a processos com elevada pressão osmótica ou elevada concentração de etanol. Este fato é de extrema importância para os processos de fermentação alcoólica, no qual as células de levedura se encontram-se em ambientes de alta pressão osmótica, elevadas concentrações de etanol e até mesmo elevada temperatura.

\subsection{Acúmulo de trealose em microrganismos}

A biossintese da trealose é realizada pelas enzimas sintetase de trealose-6-fosfato e trealose-6-fosfato-fosfatase, como é mostrado na Figura 1.

Panek et alii (1990) citam que células de Saccharomyces cerevisiae são capazes de acumular dois tipos de carboidratos: a trealose e o glicogênio. Segundo estes autores, ambos possuem a função de manutenção, diferenciação e sobrevivência de leveduras. Embora Crowe et alii (1991) citem que o glicogênio poderia ser transformado em trealose e vice-versa, acredita-se que o glicogênio não contribua para a sintese de trealose. 


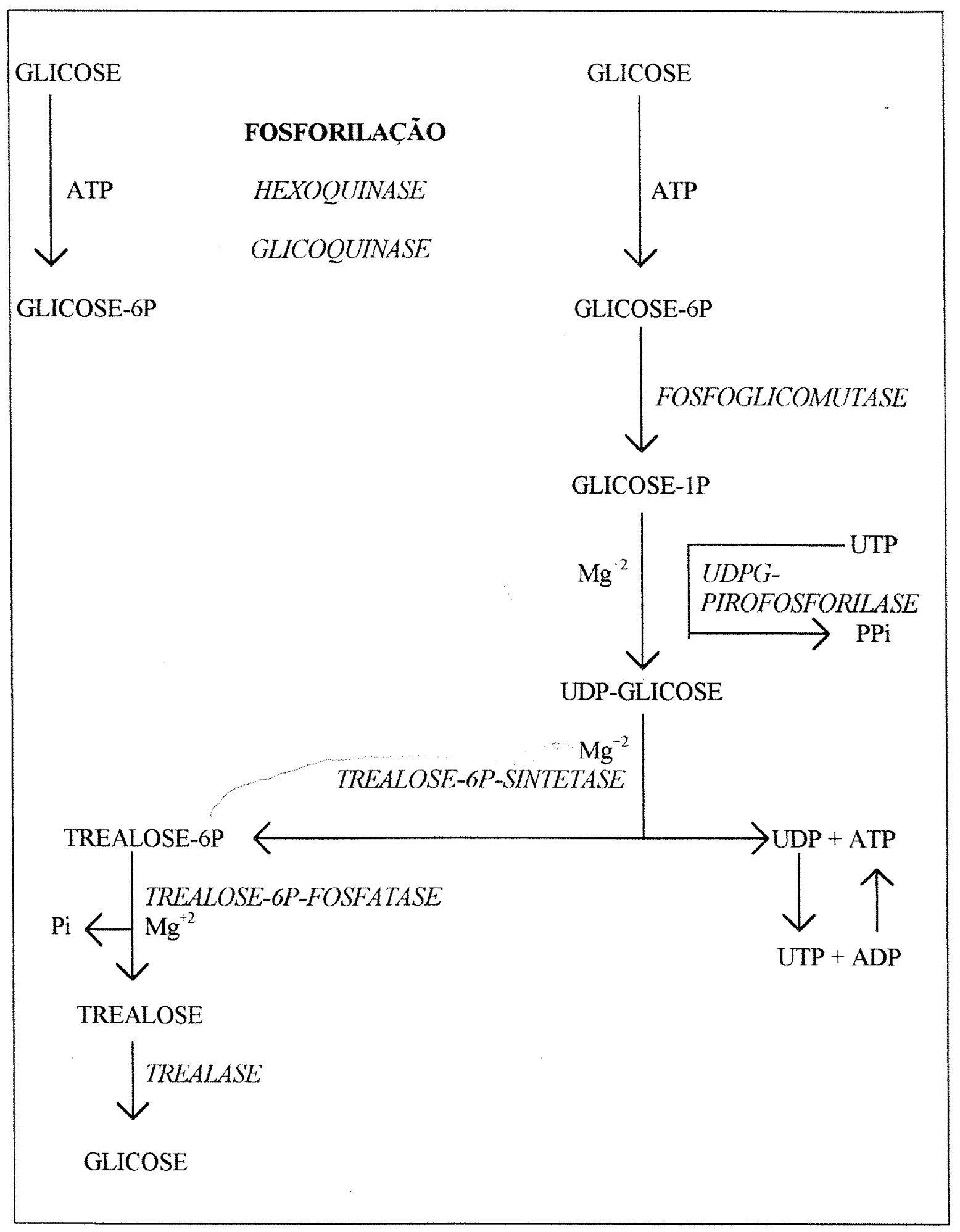

Figura 1 - Biossintese e degradação da trealose. Fonte: Gutierrez (1994). 
Segundo Hottinger et alii (1987a) as células de Saccharomyces cerevisiae não convertem suas consideráveis reservas de glicogênio em trealose, afirmando ainda que a trealose é acumulada em períodos de crescimento reduzido ou nulo. Concordando, Hino et alii (1990) relatam que o maior acúmulo de trealose ocorre na fase estacionária de crescimento.

Segundo Panek (1962) a trealose é sintetizada quando cessa a sintese de aminoácidos, uma vez que ocorre competição entre trealose e aminoácidos por glicose-6-fosfato.

De acordo com Panek (1985) cepas de Saccharomyces cerevisiae apresentaram 35\% de viabilidade após 25 dias em meio sem nutrientes, no entanto mutantes com deficiência na atividade de trealose-6-fosfato-sintetase somente permaneceram viáveis por aproximadamente 14 dias.

Thevelein (1984) cita que o acúmulo de trealose está associado a periodos de reduzida taxa de crescimento. Sua síntese é mais intensa durante o processo de diferenciação e períodos de deficiência de nutrientes.

Segundo Panek (1971) as condições anaeróbias reduzem a quantidade de trealose acumulada pelas leveduras porque a energia produzida não permite $\mathrm{o}$ armazenamento da trealose. Grba et alii (1975) também citam que, em leveduras de panificação, a síntese deste carboidrato é favorecida por condições aeróbias quando comparadas às condições anaeróbias. Porém, Gutierrez (1990) conseguiu o acúmulo de trealose pelas leveduras em anaerobiose durante fermentação alcoólica, conseguindo resultados consistentes de acúmulo de trealose, o qual atingiu até $14,97 \%$ (expresso em gramas de glicose por $100 \mathrm{~g}$ de matéria seca), com a metodologia utilizada.

Segundo Penna \& Fernandes (1994) o nível de trealose aumenta em cerca de 15 vezes dentro das células de levedura quando estas são expostas a um tratamento térmico. Esta trealose é armazenada no citosol da célula e está relacionada com a proteção das células sob condições de estresse.

Segundo Ribeiro et alii (1994) houve um acúmulo de trealose em cepas de Saccharomyces cerevisiae quando estes foram transferidos de 23 para $36^{\circ} \mathrm{C}$. Este acúmulo foi 
provavelmente devido a dois fatores: efeito da temperatura sobre os transportadores de glicose da membrana e aumento do número de moléculas do transportador.

Segundo Attfield (1987) o acúmulo de trealose também pode ocorrer quando células de levedura são expostas ao etanol, sulfato de cobre ou peróxido de hidrogênio a $30^{\circ} \mathrm{C}$. Panek et alii (1993) também afirmam que células de Saccharomyces cerevisiae acumulam trealose quando expostas a etanol ou peróxido de hidrogênio sob temperaturas acima de $28^{\circ} \mathrm{C}$, sugerindo que isto é uma resposta fisiológica ao estresse.

Células de Saccharomyces cerevisiae incubadas na presença de 18\% de sorbitol apresentaram grande acúmulo de trealose e adquiriram 100\% de viabilidade (Panek, 1991).

Segundo Tran-Dinh et alii (1991) a anfotericina B exerce uma influência marcante no consumo de glicose e na produção de metabólitos pelas leveduras. Os autores afirmam que, numa concentração de $1 \mu \mathrm{M}$ de anfotericina $\mathrm{B}$, o consumo de glicose e a produção de etanol pelas leveduras decrescem, enquanto que a produção de glicerol e de trealose no citosol da célula aumentam.

A única enzima responsável pela degradação da trealose em leveduras do gênero Saccharomyces, segundo Panek et alii (1987), é a trealase.

Células de Saccharomyces cerevisiae contém duas trealases intracelulares e solúveis, localizadas diferentemente dentro da célula, uma no citosol e outra no vacúolo. A atividade da trealase citosólica é alta em células sob crescimento exponencial em meio com açúcares fermentáveis e cai rapidamente assim que a célula entra na fase estacionária, coincidindo com o início da biossíntese da trealose. A trealase vacuolar é somente detectada em células em estado estacionário ou em culturas crescendo sob condições aeróbicas (San-Miguel \& Arguelles, 1994)

No entanto, Keller et alii (1982) e Thevelein (1984) citam que a trealose está localizada no citosol da célula enquanto a trealase só é encontrada nos vacúolos.

Eleutherio et alii (1993b), trabalhando com células de Saccharomyces cerevisiae, encontraram que a trealose deve estar presente nos dois lados da camada de lipídios da membrana celular para oferecer proteção contra o estresse. Para a presença da trealose nos dois lados da membrana há necessidade de um carregador, uma vez que este carboidrato é 
produzido no citosol da célula. Segundo Crowe et alii (1991) Saccharomyces cerevisiae possui um carregador para a trealose.

\subsubsection{Fatores que afetam o acúmulo de trealose}

\subsubsection{Leveduras}

Gutierrez (1989) cita que as leveduras mais utilizadas para a produção de álcool apresentam diferentes capacidades de acumular trealose anaerobicamente. No estudo comparativo quanto ao acúmulo de trealose em três linhagens do gênero Saccharomyces, o autor concluiu que Saccharomyces cerevisiae (M-300-A) apresentou 8,17g de trealose por $100 \mathrm{~g}$ de matéria seca, Saccharomyces cerevisiae (panificação) e Saccharomyces cerevisiae (IZ-1904) apresentaram 6,35g e 3,58g de trealose por $100 \mathrm{~g}$ matéria seca, respectivamente. O fato do maior teor de trealose ser encontrado na levedura M-300-A poderia explicar a maior resistência desta levedura a altas concentrações de sacarose e temperaturas mais elevadas.

\subsubsection{Temperatura e pH}

Os resultados apresentados por Gutierrez (1989) mostram que em três linhagens de Saccharomyces (M-300-A, panificação e IZ-1904) houve uma redução no acúmulo de trealose quando a temperatura aumentou de 12 para $26^{\circ} \mathrm{C}$, e um aumento foi observado quando a temperatura passou de 26 para $35^{\circ} \mathrm{C}$. Este maior acúmulo de trealose a $35^{\circ} \mathrm{C}$ está de acordo com os estudos de Grba et alii (1975) que encontraram valores mais elevados de trealose a $40^{\circ} \mathrm{C}$. Uma possível explicação para a menor formação de trealose a $26^{\circ} \mathrm{C}$ do que a $12^{\circ} \mathrm{C}$ e $35^{\circ} \mathrm{C}$ poderia ser dada pela intensidade de crescimento, uma vez que houve maior crescimento da levedura a $26^{\circ} \mathrm{C}$ que a $12^{\circ} \mathrm{C}$ e a $35^{\circ} \mathrm{C}$.

Segundo Attfield (1987) a trealose se acumula em leveduras quando a temperatura do meio passa de 30 para $45^{\circ} \mathrm{C}$, e o pico de acúmulo acontece após 90 minutos, concordando 
com Grba et alii (1975) que também relatam que a temperatura ótima para o acúmulo de trealose é de $45^{\circ} \mathrm{C}$.

Quando as células de levedura foram colocadas sob temperaturas entre 36 e $40^{\circ} \mathrm{C}$ por 120 minutos elas apresentaram viabilidade de $80 \%$ após serem submetidas a um choque térmico $\left(50^{\circ} \mathrm{C}\right.$ por 8 minutos). Esta termotolerância adquirida foi relacionada com a ativação da trealose-6-fosfato sintase e consequente acúmulo de trealose (Panek et alii, 1993).

No estudo sobre o acúmulo de trealose em função do pH nas mesmas três linhagens de Saccharomyces citadas anteriormente por Gutierrez (1990), o autor concluiu que houve maior acúmulo de trealose em $\mathrm{pH}$ 4,5 que em $\mathrm{pH}$ 3,0 para as leveduras M-300-A e de panificação. A levedura IZ-1904 apresentou maior produção de trealose em pH 3,0. No caso do $\mathrm{pH}$ não ocorreu relação com o crescimento como verificado para a temperatura.

\subsubsection{Concentração de açúcar}

Gutierrez (1990) estudou os teores de trealose acumulados em três linhagens de Saccharomyces (M-300-A, panificação e IZ-1904) quando expostas a quatro concentrações de sacarose $(8,11,14$ e 16\%) durante a fermentação alcoólica, e concluiu que aumentando-se a concentração do carboidrato no meio fermentativo ocorreu maior acúmulo de trealose, medida ao final da fermentação. Em maiores concentrações de açúcar ocorreu provavelmente também maior formação de etanol, o que poderia ocasionar menor crescimento de leveduras acarretando maior acúmulo de trealose e ainda maior disponibilidade de ATP para a síntese da trealose.

Panek (1975) cita que a trealose só se acumula e atinge concentração elevada dentro da célula quando a glicose do meio está quase esgotada, sugerindo ainda que a trealose-6fosfato-sintetase é mais ativa em baixas concentrações de glicose-6-fosfato.

A formação de trealose depende da quantidade de glicose presente no meio, uma vez que, quando esgota totalmente a glicose, cessa a sua produção (Grba et alii, 1975).

Para que um composto seja considerado de reserva ele deve ser acumulado quando as fontes externas de nutrientes são abundantes, para ser utilizado em periodos desfavoráveis. A 
trealose apresenta um comportamento diferente, ou seja, é acumulada durante a fase lag da diauxia, quando o meio está exaurido em glicose (Lille \& Pringle, 1980).

\subsubsection{Fontes de nitrogênio}

Segundo Trevelyan \& Harrison (1956a), no início do processo fermentativo, a trealose armazenada na levedura é degradada, atingindo um teor mínimo após 30 minutos de fermentação. Se o meio de fermentação com glicose for deficiente em nitrogênio vai ocorrer ressintese da trealose podendo atingir niveis superiores ao inicial. No caso de usar meio completo não vai ocorrer ressintese da trealose.

$\mathrm{O}$ processo de multiplicação da levedura é estimulado quando se aumenta a disponibilidade de nitrogênio. Segundo Panek (1962 e 1963) o acúmulo de reservas ocorre na fase de maturação das células. Assim quanto menor o crescimento das células, maior o acúmulo de trealose (Parada \& Acevedo, 1983).

O estudo realizado por Gutierrez (1989) sobre o acúmulo de trealose e viabilidade celular de três Saccharomyces em três concentrações de extrato de levedura, mostrou que aumentando-se a disponibilidade de nitrogênio na forma de aminoácidos ocorreu grande redução no teor de trealose nas linhagens M-300-A, panificação e IZ-1904, embora não tenha ocorrido alteração na mesma intensidade, com a viabilidade celular.

Concentrações mais altas de trealose são encontradas em Saccharomyces cerevisiae quando a concentração de nitrogênio do meio é baixa. Segundo os autores a glicose é convertida em carboidratos de reserva, trealose e glicogênio, quando praticamente todo o nitrogênio do meio já tenha sido utilizado para a produção de biomassa (Sierkstra et alii, 1994).

Szopa et alii (1992) também citam que as condições ótimas de crescimento não estimulam o acúmulo de trealose pelas leveduras, o qual só ocorre quando o crescimento é limitado por restrição de nitrogênio e fósforo.

Quando Gutierrez (1989) comparou fontes de nitrogènio na forma amoniacal e uréia, observou que com o sulfato de amônio ocorreu menor acúmulo de trealose que com a uréia. 
Provavelmente isto possa ser explicado pelo menor $\mathrm{pH}$ do meio quando se emprega sulfato de amônio como fonte de nitrogênio.

De qualquer forma, aumentando-se a disponibilidade de nitrogênio no meio fermentativo ocorreu menor acúmulo de trealose, confirmando as observações de Trevelyan \& Harrison (1956a) e Lillie \& Pringle (1980). Com a maior disponibilidade de nitrogênio, as leveduras desviam glicose para a sintese de aminoácidos e proteínas reduzindo o acúmulo de trealose.

\subsubsection{Inibidores}

Diversos inibidores afetam a formação de trealose. Trevelyan (1958) cita que em presença de fluoreto as células de levedura apresentam-se sem trealose, embora Panek (1962) relate que o fluoreto de sódio não afetou a formação de trealose em condições anaeróbias.

Trevelyan (1958) também cita que o arseniato inibiu a sintese de trealose e glicogênio. Trevelyan et alii (1952) relataram que azida de sódio inibiu a síntese de carboidratos em células de levedura.

Gutierrez (1989) verificou que 2,4-dinitrofenol promoveu redução no acúmulo de trealose e queda na viabilidade celular em linhagens de Saccharomyces. A explicação para a redução da trealose poderia ser dada pela ativação de ATPase, reduzindo assim os níveis de ATP e UTP necessários para a biossintese da trealose.

Gutierrez et alii (1991) estudaram o efeito da adição de ácido acético sobre o acúmulo de trealose e a viabilidade celular, concluindo que a adição de ácido acético promoveu redução no teor de trealose embora não tenha ocorrido queda na viabilidade celular. Provavelmente, a redução no teor de trealose ocorreu devido a restrição à entrada de açúcar na célula de levedura, reduzindo assim o nivel de glicose-6-fosfato para a síntese de trealose.

A adição de ácido octanóico inibiu a fermentação alcoólica realizada por Saccharomyces cerevisiae e o acúmulo de trealose, contudo não afetou a degradação endógena da trealose. Esta inibição, segundo Gutierrez (1993), poderia ser explicada pela ligação do ácido octanóico à hexoquinase ou outra proteína da membrana plasmática uma vez 
que não são necessárias para a fermentação endógena. A degradação da trealose poderia ser devida a uma ativação da trealase.

Culturas de Saccharomyces cerevisiae foram cultivadas em quatro meios diferentes que continham, por litro: (1) $130 \mathrm{~g}$ de sacarose, $\mathrm{lg}$ de extrato de levedura e $4,4 \mathrm{~g}$ de sais nutrientes; (2) idêntico ao meio 1 só que acrescido de ácidos graxos $(0,4 \mathrm{~g}$ de ácido capróico, $0,2 \mathrm{~g}$ de ácido caprílico e $0,2 \mathrm{~g}$ de ácido cáprico); (3) idêntico ao meio 2 , acrescido de $5 \mathrm{~g}$ de farinha de soja; e (4) idêntico ao meio 2 , acrescido de $5 \mathrm{~g}$ de farinha de milho. As células que foram cultivadas no meio 1 tiveram a sua concentração de trealose diminuida de $7,2 \%$ para $3,4 \%$, com $74 \%$ de manutenção da viabilidade. As culturas do meio 2 foram para $0,5 \%$ de trealose, com $22 \%$ de manutenção da viabilidade; as do meio 3 para $3,6 \%$ de trealose e $38 \%$ de manutenção da viabilidade e as do meio 4 para $5,6 \%$ de trealose e $60 \%$ de manutenção da viabilidade. Os autores concluiram que as farinhas (particularmente a de milho) diminuiram o efeito adverso dos ácidos graxos na viabilidade das células por permitir um maior acúmulo de trealose pelas mesmas (Maia \& Nelson, 1993).

\subsection{Trealose e agentes estressantes}

A velocidade da fermentação durante o processo fermentativo sofre influência de diversos fatores, dentre eles a viabilidade celular, a temperatura de fermentação, a pressão osmótica, o tipo de açúcar dissolvido no meio e o efeito das altas concentrações de etanol presentes no meio. A trealose parece ter a função de proteção contra os efeitos destes fatores de estresse, melhorando as condições das células e, portanto, o seu desempenho fermentativo.

Segundo Panek et alii (1993) o acúmulo de trealose é responsável pela proteção das células de leveduras contra altas temperaturas, choque osmótico, efeitos tóxicos do etanol, dessecação e desidratação, o que concorda com Maia \& Nelson (1993) os quais citam que o acúmulo de trealose intracelular em leveduras está associado com sua resistência a fatores fisiológicos de estresse, tais como concentração de etanol, choque térmico, estresse osmótico e dessecação. 


\subsubsection{Trealose e termotolerância}

A temperatura é uma das condições ambientais que mais afetam a atividade dos microrganismos, influenciando no crescimento, metabolismo, viabilidade celular e capacidade fermentativa das leveduras.

Segundo Bossier et alii (1993) a termotolerância de células de Saccharomyces cerevisiae é definida como sendo a habilidade das células em sobreviverem a um choque térmico drástico (mudança de $28-37$ para $52^{\circ} \mathrm{C}$ ) durante um curto período de tempo (10 a 20 minutos). As leveduras Saccharomyces cerevisiae podem sobreviver a um choque térmico drástico se forem previamente expostas a um choque térmico não letal $\left(40-45^{\circ} \mathrm{C}\right)$. Segundo os autores, uma variedade de condições de estresse não letais também podem induzir à aquisição de termotolerância por células de leveduras.

Em estudo realizado por Hottinger et alii (1992) os níveis de trealose em células de Saccharomyces cerevisiae foram diretamente relacionados com a termotolerância, sugerindo então uma função de termoproteção às células da trealose. Segundo os autores as células de levedura acumulam rapidamente trealose quando mudadas de 27 para $40^{\circ} \mathrm{C}$.

Segundo De Virgilio et alii (1991) o acúmulo de trealose e a aquisição de termotolerância por leveduras Saccharomyces cerevisiae estão diretamente relacionados e são modulados pela síntese de proteína do choque térmico.

Segundo Attfield (1987) a sintese de proteinas do choque térmico acompanha o acúmulo de trealose em leveduras Saccharomyces cerevisiae, concluindo que ambos os fatores agem de modo a proteger as células contra agentes estressantes.

Segundo Hottinger et alii $(1987 \mathrm{a}, \mathrm{b})$ a elevação da temperatura do meio de cultivo de Saccharomyces cerevisiae de 27 para $40^{\circ} \mathrm{C}$ leva a um aumento no acúmulo de trealose, estando este acúmulo relacionado com a aquisição de termotolerância pela levedura. Hottinger et alii (1987b) constataram ainda que este aumento de temperatura proporciona um aumento de seis vezes na atividade da enzima responsável pela biossíntese da trealose, a trealose-6-fosfato-sintetase, sugerindo estes que esta enzima possa ser uma proteína do choque térmico. Segundo os autores, a ativação da enzima trealose-6-fosfato-sintase por 
choque térmico em culturas de Saccharomyces cerevisiae pode ser devido à fosforilação desta enzima.

No entanto, Panek et alii (1990), comparando linhagens de Saccharomyces cerevisiae que acumulavam trealose e linhagens que não, não encontraram diferença significativa entre elas quanto à resistência ao choque térmico $\left(52^{\circ} \mathrm{C}\right.$ por 2 minutos), concluindo que não somente o acúmulo de trealose e a síntese de proteínas do choque térmico é que estavam relacionados com a sobrevivência das células ao choque térmico.

Segundo Hottinger et alii (1994) o acúmulo de trealose em células de leveduras Saccharomyces cerevisiae é iniciada por estimulos internos que ativam uma resposta da célula ao choque térmico. Os autores afirmam que o nivel de trealose das células está diretamente relacionado com sua termotolerância, sugerindo uma função de proteção desta substância. Os mesmos autores, examinando o efeito da trealose na estabilidade térmica de proteínas, parâmetro que parece ser o mais importante para a termotolerância, sugerem que o acúmulo de trealose aumenta a termotolerância das células de levedura por aumentar a estabilidade das proteínas em células intactas.

De Virgílio et alii (1994), estudando o metabolismo da trealose através de mutantes incompletos em genes que codificam enzimas chaves do metabolismo, afirmam que existe uma forte evidência genética que a síntese de trealose por indução térmica é um importante fator que induz a termotolerância em leveduras.

Segundo Eleutherio et alii (1993a) quando as células de leveduras passam de 28 para $40^{\circ} \mathrm{C}$ por uma hora, elas acumulam trealose e este acúmulo está relacionado com a aquisição de tolerância ao calor, medida pela sua resistência ao choque térmico $\left(50,5^{\circ} \mathrm{C}\right.$ por 8 minutos).

Segundo Arguelles (1994) culturas de Saccharomyces cerevisiae apresentam queda de viabilidade quando mudadas de 28 para $42^{\circ} \mathrm{C}$, porém aumentam a fração de células viáveis sob tratamento térmico mais severo $\left(52,5^{\circ} \mathrm{C}\right.$ por 5 minutos). Os autores ainda sugerem que outros fatores além do acúmulo de trealose estão relacionados com a termotolerância.

Wienkler et alii (1991) verificaram que mutantes de Saccharomyces cerevisiae que acumulavam trealose mas não produziam proteína de choque térmico foram mais sensiveis ao 
choque térmico $\left(50^{\circ} \mathrm{C}\right.$ por 20 minutos) que as linhagens selvagens, concluindo que era a proteína do choque térmico, e não a trealose, que conferia termotolerância às leveduras.

Segundo Nwaka et alii (1994) o acúmulo de trealose e a aquisição de termotolerância por leveduras, sob certas condições, não caminham paralelamente. Um mutante deficiente na degradação de trealose mostrou, após mudança de 40 para $30^{\circ} \mathrm{C}$, baixa termotolerância apesar de apresentar uma alta concentração de trealose. Quando glicose foi acrescentada ao meio de cultivo de células de levedura normais em fase estacionária com alta concentração de trealose e alta termotolerância, a concentração de trealose diminuiu enquanto que a termotolerância permaneceu alta. Um mutante que sintetiza proteínas do choque térmico apresentou durante o seu crescimento exponencial uma baixa concentração de trealose e uma alta termotolerância. Por isso os autores sugerem que, sob certas condições, o acúmulo de proteínas do choque térmico, e não de trealose, é que é responsável pela termotolerância em leveduras.

\subsubsection{Trealose e liofilização}

Segundo Grba et alii (1975), para se obter uma cultura de levedura desidratada ativa, deve-se incubar previamente a cultura sob uma temperatura tal que se obtenha um alto acúmulo de trealose, o que confere às células uma alta resistência à desidratação.

Segundo Leslie et alii (1994) existe uma clara correlação entre a quantidade de trealose presente em células de Saccharomyces cerevisiae e sua habilidade em tolerar a desidratação. Segundo os autores somente quando a trealose está presente é que a transição das células para a fase seca ocorre sem grande perda de viabilidade. Os autores recomendam que, para que a viabilidade da cultura seja mantida após a desidratação, as células devem ser reidratadas com água morna (acima de $40^{\circ} \mathrm{C}$ ).

Hino et alii (1990) associaram o teor de trealose endógena à resistência de leveduras ao congelamento, uma vez que os cepas de Saccharomyces cerevisiae mais tolerantes ao congelamento, mostrando alta taxa de sobrevivência, mostraram também maior habilidade em acumular trealose quando comparados aos cepas mais sensíveis. 
Gélinas et alii (1989), avaliando o efeito das condições de crescimento e conteúdo de trealose no congelamento de leveduras de panificação, citam que em condições anaeróbias e à baixa temperatura de crescimento $\left(20^{\circ} \mathrm{C}\right)$ ocorreu redução no teor de trealose e na resistência das leveduras ao congelamento. Durante o armazenamento destas leveduras a $4^{\circ} \mathrm{C}$ por um período de 11 semanas houve redução na viabilidade celular, acompanhada também pela queda no teor de trealose.

\subsubsection{Trealose e tolerância ao etanol}

O etanol inibe o metabolismo das leveduras e também causa efeitos desfavoráveis às suas células, tais como diminuição da taxa de crescimento e redução na viabilidade celular.

Segundo Watson \& Cavichioli (1983) a levedura Saccharomyces cerevisiae adquire

tolerância ao etanol quando mudada de 37 para $52^{\circ} \mathrm{C}$ por 5 minutos ou de 23 para $37^{\circ} \mathrm{C}$ por 30 minutos. Os autores concluíram que, sob estas condições, a levedura produz proteinas do choque térmico para adquirirem a termotolerância e as relacionaram com a tolerância ao etanol.

Segundo Mansure et alii (1994) o etanol presente no meio provoca a saida de eletrólitos do interior das células, porém a presença de trealose dentro ou fora da membrana inibe este efeito. Os autores também sugerem que o comportamento dos lipídios da membrana plasmática, juntamente com a trealose, desempenham um papel de aumentar a tolerância das células ao etanol. Os autores ainda observaram uma correlação positiva entre viabilidade celular e concentração de trealose.

\subsubsection{Trealose e osmotolerância}

A exposição da célula de levedura a condições de alta osmolaridade leva a uma desidratação e colapso da célula, ocasionando uma queda na viabilidade da cultura. No entanto, em condições de alta osmolaridade, a célula de levedura sintetiza proteínas do choque 
térmico e trealose, provavelmente para proteger os componentes celulares e para facilitar a reparação e recuperação das células (Mager \& Varela, 1993). 


\section{MATERIAIS e MÉTODOS}

\subsection{Culturas}

As seguintes leveduras foram utilizadas nos experimentos: Saccharomyces cerevisiae (M-300-A, também conhecida por TA), Saccharomyces cerevisiae (IZ-1904) e Saccharomyces cerevisiae (SA - isolada da Usina Santa Adélia S/A). Estas leveduras encontravam-se em estado liofilizado, fazendo parte da coleção de microrganismos do Departamento de Ciência e Tecnologia Agroindustrial da Escola Superior de Agricultura "Luiz de Queiroz" - Universidade de São Paulo, Piracicaba-SP.

Estas leveduras foram escolhidas por exibirem performances fermentativas diferenciadas e se apresentarem com diferentes tolerâncias aos diversos agentes estressantes da fermentação.

A levedura IZ-1904 apresenta drástica queda da sua viabilidade celular com os reciclos fermentativos devido à exaustão de seus carboidratos de reserva (glicogênio e principalmente trealose), sendo portanto vulnerável e pouco tolerante aos agentes estressantes da fermentação (Basso et al, 1988).

A levedura TA se mostra mais vigorosa (maior viabilidade celular, crescimento e eficiência fermentativa) que a levedura IZ-1904, mantendo mais altos os seus teores de glicogênio e trealose e a sua viabilidade celular com os reciclos fermentativos (Basso et al, 1988). Porém, apesar da levedura TA ser mais resistente que a levedura IZ-1904 às adversidades do meio no processo fermentativo, ela também não consegue permanecer no processo industrial por longo período de tempo (Basso \& Amorim, 1994). 
A levedura SA apresenta maior eficiência fermentativa e maior viabilidade celular com os reciclos que a levedura TA. Apesar de ambas as leveduras mostrarem-se igualmente tolerantes ao etanol, outras características tais como termotolerância, osmotolerância, tolerância à acidez ou outras devem ocorrer na levedura SA, fazendo com que esta seja mais resistente às condições estressantes da fermentação industrial que a levedura TA e conseguindo assim se manter no processo industrial por longo período de tempo (Basso \& Amorim, 1994).

\subsection{Meio de cultivo para a reativação das culturas de levedura}

Para a reativação e o crescimento das células de levedura foi utilizado o meio de cultivo líquido YEPD ( $1,0 \%$ de extrato de levedura, $1,0 \%$ de peptona e $2,0 \%$ de dextrose), uma vez que se mostra adequado para a multiplicação de todas as leveduras estudadas.

\subsection{Manutenção das culturas de leveduras}

Para manutenção das culturas de levedura foi utilizado o método de liofilização, seguindo procedimentos descritos por Kirsop (1984) e Chang \& Elander (1986). O aparelho utilizado foi o VIRTIS (Division of Center Medical/Health Supply Corp.), o qual proporciona uma taxa de resfriamento de $3^{\circ} \mathrm{C}$ por minuto.

\subsection{Reativação das culturas}

As culturas liofilizadas foram reativadas em tubos de ensaio $(150 \mathrm{~mm} \times 16 \mathrm{~mm}$, altura e diâmetro externo, respectivamente) contendo $5,0 \mathrm{ml}$ de meio de cultivo líquido YEPD. Depois de incubadas a $26^{\circ} \mathrm{C} \pm 1^{\circ} \mathrm{C}$ por 24 horas, as culturas foram repicadas e incubadas novamente nas mesmas condições, por mais 48 horas (Figura 2). 


\subsection{Multiplicação das leveduras reativadas}

Para se obter maior massa de levedura, $0,25 \mathrm{ml}$ da suspensão da levedura reativada foi espalhado com uma espátula de Drigalsky em cada uma de 12 placas de Petri contendo o meio de cultivo sólido YEPD ( $1,0 \%$ de extrato de levedura, 1,0\% de peptona, 2,0\% de dextrose e $1,5 \%$ de ágar). Depois das placas serem incubadas a $26^{\circ} \mathrm{C} \pm 1^{\circ} \mathrm{C}$ por 48 horas, a massa de levedura foi raspada das placas com o auxilio de uma alça de Henle e suspensa em $300 \mathrm{ml}$ de solução salina $(0,9 \%$ de $\mathrm{NaCl})$ contida em Erlenmeyer (Figura 2).

\subsection{Meio de fermentação para o acúmulo da trealose endógena}

O meio de fermentação utilizado para estimular o acúmulo da trealose endógena pelas leveduras foi constituído por uma solução tampão de citrato de potássio, $\mathrm{pH} 4,0$, acrescida de $2,0 \%$ de glicose, esterilizado em autoclave a 1,0 atmosfera de pressão, a $121^{\circ} \mathrm{C}$ durante 20 minutos. 
CULTURAS LIOFILIZADAS

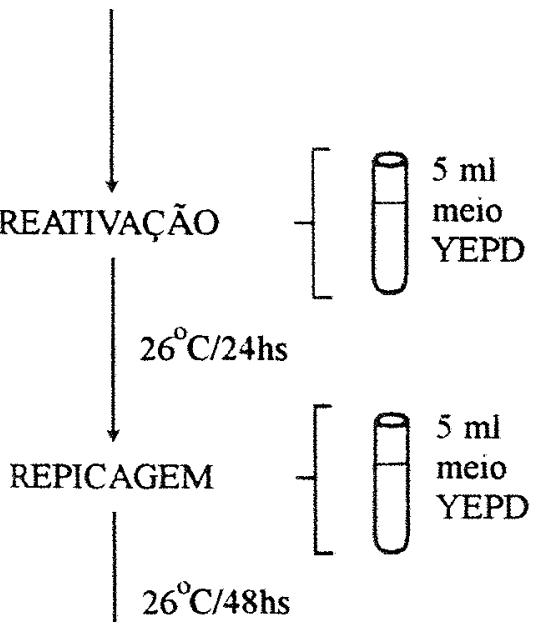

ESPALHAMENTO DA SUSPENSÃO

em meio sólido YEPD
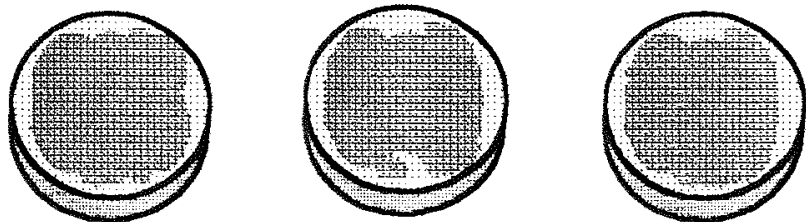

$26^{\circ} \mathrm{C} / 48 \mathrm{hs}$

Raspagem das placas e suspensão em solução salina

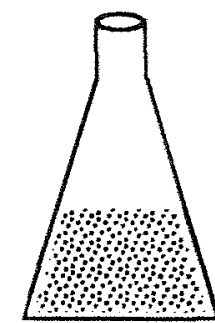

CULTURAS REATIVADAS E MULTIPLICADAS

Figura 2 - Esquema para reativação e multiplicação das culturas de levedura 


\subsection{Teste para verificar o acúmulo e a degradação da trealose endógena pelas leveduras}

Optou-se por fazer o acúmulo da trealose endógena pelas leveduras em anaerobiose, devido aos bons resultados obtidos por Gutierrez (1990), pelo fato dos ensaios laboratoriais serem mais facilmente executados em anaerobiose e pelo interesse em simular uma condição de fermentação alcoólica industrial.

Assim, um teste foi realizado para verificar como variava o acúmulo da trealose endógena pelas leveduras em função do tempo de fermentação.

Neste teste, a massa de cada levedura que foi suspensa em solução salina, foi dividida igualmente entre três tubos de centrifuga de $150 \mathrm{ml}$ de capacidade e, em seguida, centrifugados a $800 \mathrm{G}$ por 10 minutos. Depois de eliminado o sobrenadante, foi feita a pesagem da massa de levedura de cada tubo de ensaio e foi então preparada uma suspensão $10 \%$ de massa úmida $(\mathrm{p} / \mathrm{v})$ de cada levedura reativada em relação ao meio de fermentação. A fermentação foi conduzida a $45^{\circ} \mathrm{C}$, com agitações casuais, e foram retiradas amostras para se determinar o teor da trealose endógena nos seguintes tempos de fermentação: $0,60,120,180,240$ e 300 minutos de fermentação (Figura 3). 


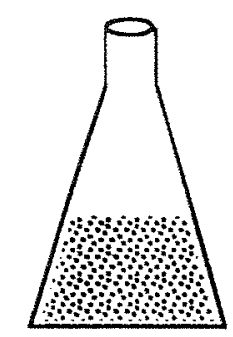

SUSPENSÃO DE LEVEDURA MULTIPLICADA

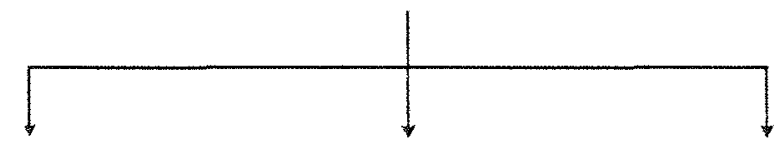

9
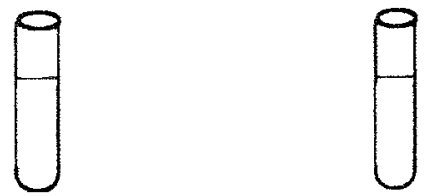

FERMENTAÇĀO A $45^{\circ} \mathrm{C}$ - suspensăo $10 \%$ de levedura em meio de fermentacăo tampão citrato-K, $\mathrm{pH} 4,0+2 \%$ de glucose

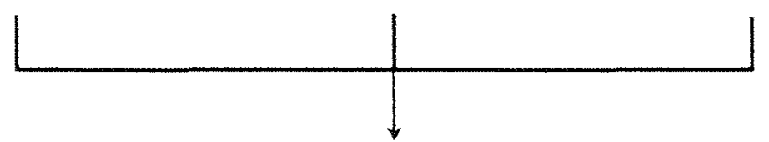

RETIRADA DE AMOSTRAS PARA DETERMINACĀO DA

TREALOSE ENDÓGENA aos 0, 60, 120, 180, 240 e 300 minutos de fermentaçăo

Figura 3 - Esquema do teste para veriticar o acúmulo e a degradaçāo da trealose endógena pelas leveduras 


\subsection{Acúmulo e esgotamento da trealose endógena}

A massa de levedura que foi supensa em solução salina, foi dividida igualmente entre nove tubos de centrífuga de $150 \mathrm{ml}$ de capacidade e, em seguida, centrifugados a $800 \mathrm{G}$ por 10 minutos. Depois de eliminado o sobrenadante, foi feita a pesagem da massa de levedura de cada tubo de ensaio.

Para estimular o acúmulo da trealose endógena, foi preparada uma suspensão $10 \%$ de massa úmida $(\mathrm{p} / \mathrm{v})$ de cada levedura reativada em relação ao meio de fermentação. A fermentação foi conduzida a $45^{\circ} \mathrm{C}$ por 2 horas (Attfield, 1987; Gutierrez, 1993). Este tempo de fermentação foi escolhido devido aos resultados obtidos no teste para verificação do acúmulo da trealose endógena em função do tempo de fermentação.

A levedura reativada sem passar pelo tratamento de acúmulo de trealose foi considerada como levedura esgotada em trealose, devido à mesma apresentar um baixo teor relativo de trealose endógena, conforme verificado no teste de acúmulo da trealose endógena em função do tempo de fermentação.

Estes procedimentos são mostrados na Figura 4.

\subsection{Avaliação da influência da trealose na manutenção da viabilidade de células de leveduras submetidas ao processo de liofilização}

Para avaliar a influência da trealose endógena na manutenção da viabilidade de células de levedura submetidas ao processo de desidratação por liofilização, ambas as leveduras tratadas (as esgotadas e as com acúmulo de trealose) foram centrifugadas a 800G por 10 minutos. Foi feita uma primeira lavagem para purificação da massa de levedura com $50 \mathrm{ml}$ de água destilada e em seguida uma outra centrifugação a $800 \mathrm{G}$ por 10 minutos. Depois de eliminado o sobrenadante, foi feita uma pesagem da massa de levedura de cada tubo de ensaio para que na segunda lavagem fosse preparada uma suspensão $12 \%$ de massa úmida $(\mathrm{p} / \mathrm{v})$ de levedura em relação à água destilada. Isto foi feito para se coletar uma amostra de massa de levedura conhecida para se determinar a trealose endógena. Foram então coletadas amostras 
de $1,0 \mathrm{ml}$ para se determinar a viabilidade celular e de $0,5 \mathrm{ml}$ para se determinar o teor de trealose endógena. Após nova centrifugação a $800 \mathrm{G}$ por 10 minutos, a massa de levedura remanescente foi liofilizada.

Para se avaliar o efeito da trealose como crioprotetor para as células de levedura submetidas à liofilização, a massa de levedura a ser liofilizada foi ressuspensa em uma solução crioprotetora contendo $10 \%$ de trealose, comparando-a com outras duas soluções crioprotetoras: sacarose a $10 \%$ e leite desnatado a $10 \%$.

A determinação da viabilidade celular foi realizada antes da liofilização e aos 10,40 e 90 dias após o processo de liofilização.

O experimento com cada levedura reativada foi realizado em triplicata.

Estes procedimentos são mostrados na Figura 4. 


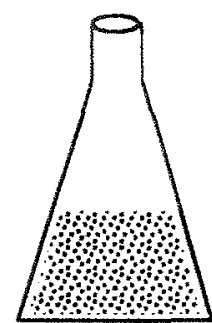

SLSPENSÃO DE LEVEDURA MULTIPLICADA

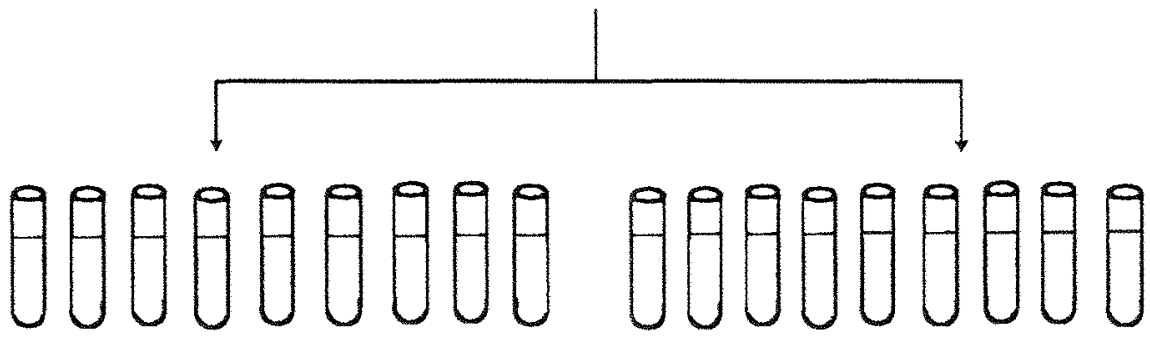

TRATAMENTO PARA ACUMULAR LEVEDURA SEMTRATAMENTO TREALOSE ENDÓGENA - suspensão esgotada em trealose endógena $10 \%$ de levedura em meio tampão citrato-K, $\mathrm{pH} 4,0+2 \%$ de gluoose, a $45^{\circ} \mathrm{C}$ por 2 horas

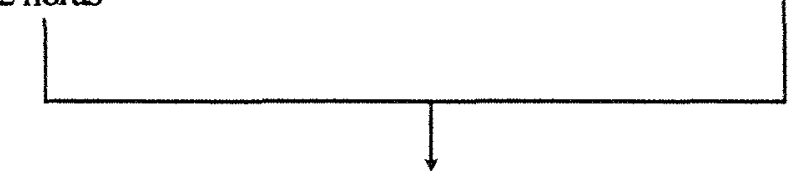

LAVAGENS E CENTRIFUGAÇÕES<smiles>[13CH2][13CH3]</smiles>

RETIRADA DE AMOSTRAS PARA DETERMINAR

- viabilidade

- teor de trealose

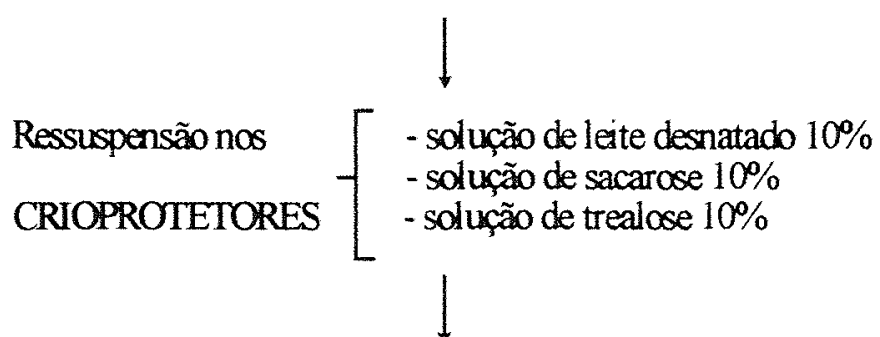

LIOFILIZAÇÃO

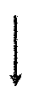

DETERMINAÇÃO DA VABILIDADE CELULAR aos 0, 10, 40 e 90 dias

Figura 5: Esquema para avaliacão da influência da trealose na viabilidade celular de leveduras submetidas ao processo de liofilização 


\subsection{Procedimentos para a liofilização}

\subsubsection{Preparo das ampolas}

As ampolas foram feitas a partir de vidro neutro, com as seguintes dimensões: $100 \mathrm{~mm}$ × $6 \mathrm{~mm}$ (comprimento e diâmetro interno, respectivamente). Colocou-se um pequeno pedaço de algodão no fundo e uma etiqueta de $2,0 \mathrm{~cm} \times 0,5 \mathrm{~cm}$ de papel de filtro com a identificação, em seguida tampou-se com algodão e esterilizou-se em autoclave $\left(121^{\circ} \mathrm{C}\right.$ por 20 minutos, a 1 atmosfera de pressão).

\subsubsection{Preparo do inóculo}

Após a centrifugação das culturas, a massa de levedura a ser liofilizada foi ressuspensa nas soluções crioprotetoras. Cada ampola recebeu $0,2 \mathrm{ml}$ de inóculo utilizando-se de pipetas Pasteur calibradas e esterilizadas.

Foi feita uma constrição a cerca de $6,5 \mathrm{~cm}$ da base da ampola após a introdução de aproximadamente $1,0 \mathrm{~cm}$ do algodão que tampa a ampola para dentro desta. As ampolas assim preparadas seguiram para o liofilizador, onde permaneceram por 6 horas a uma pressão de $10 \mathrm{~mm}$ de mercúrio e depois foram seladas à vácuo, para evitar a ação deletéria do oxigènio sobre o liófilo (Valdez, 1985).

\subsubsection{Teste para verificação do vácuo}

As ampolas foram testadas com o aparelho de alta frequência Edwards High Vacuum ST 200K MK II, sendo as ampolas com vazamento descartadas. As demais ampolas foram envolvidas em folha de alumínio para evitar exposição à luz e guardadas em geladeira $\left(4^{\circ} \mathrm{C}\right)$ para melhor manutenção da estabilidade do liófilo (Costa e Ferreira, 1991 e Kirsop, 1984). 


\subsection{Determinação da viabilidade celular}

Para se determinar a viabilidade celular, imediatamente após as ampolas serem abertas, aos 10, 40 e 90 dias após a liofilização, e as células de levedura reidratadas em $5,0 \mathrm{ml}$ de água destilada a $45^{\circ} \mathrm{C}$ (Leslie et al, 1994), coletou-se amostra de 1,0ml, a qual foi serialmente diluída e posteriormente misturada, em partes iguais, com o corante eritrosina. A seguir, com pipeta Pasteur, transferiu-se uma amostra colorida para a cầmara de Neubauer. Nesta contouse as células incolores e as coloridas de vermelho, em microscópio de campo claro, utilizandose a objetiva de 40 vezes de aumento. Foram contadas no mínimo 500 células por câmara, o que foi obtido pela diluição adequada da amostra. Para maior precisão da análise, a diluição da amostra foi tal que não mais que 50 células de levedura fossem encontradas por quadrículo de $0,01 \mathrm{~mm}^{2}$ da càmara e não menos que 10 quadrículos escolhidos ao acaso fossem contados (Amorim et al, 1989).

Para se determinar a viabilidade celular antes da liofilização, a amostra de $1,0 \mathrm{ml}$ da suspensão de levedura foi diluída e posteriormente misturada, em partes iguais, com o corante eritrosina.

\subsection{Determinação da trealose endógena}

A determinação do teor de trealose endógena foi realizada através da extração com ácido tricloroacético (TCA) a frio e determinada pelo método da antrona, segundo Trevelyan \& Harrison (1956a; 1956b). 


\subsection{Delineamento experimental e análise estatística dos dados}

Para a análise da manutenção da viabilidade celular das leveduras após liofilização foi utilizado o delineamento experimental inteiramente casualizado. Para a análise estatística dos dados foi utilizada a técnica dos Contrastes Ortogonais dentro do procedimento Modelos Lineares Generalizados, através do software SAS 6.8.

\subsection{Padronização das Tabelas e Figuras}

Para efeito de padronização das Tabelas e Figuras, será considerado como $\mathrm{Tl}$ o tratamento de esgotamento da trealose endógena das leveduras, tendo a solução de leite desnatado a 10\% como crioprotetor para a liofilização; T2 o tratamento de esgotamento da trealose endógena das leveduras, tendo a solução de sacarose a $10 \%$ como crioprotetor para a liofilização; T3 o tratamento de esgotamento da trealose endógena das leveduras, tendo a solução de trealose a 10\% como crioprotetor para a liofilização; T4 o tratamento de acúmulo da trealose endógena das leveduras, tendo a solução de leite desnatado a $10 \%$ como crioprotetor para a liofilização; T5 o tratamento de acúmulo da trealose endógena das leveduras, tendo a solução de sacarose a $10 \%$ como crioprotetor para a liofilização; e T6 o tratamento de acúmulo da trealose endógena das leveduras, tendo a solução de trealose a $10 \%$ como crioprotetor para a liofilização. 


\section{RESULTADOS}

4.1. Teste para verificar o acúmulo e a degradação da trealose endógena pelas leveduras

Os resultados do teor de trealose endógena das leveduras, em $\mathrm{mg} / 100 \mathrm{mg}$ de matéria seca, durante o tempo de fermentação estão mostrados na Tabela 1 do Apêndice.

Os valores médios do teor de trealose endógena das leveduras, em $\mathrm{mg} / 100 \mathrm{mg}$ de matéria seca, durante o tempo de fermentação estão mostrados na Figura 5.

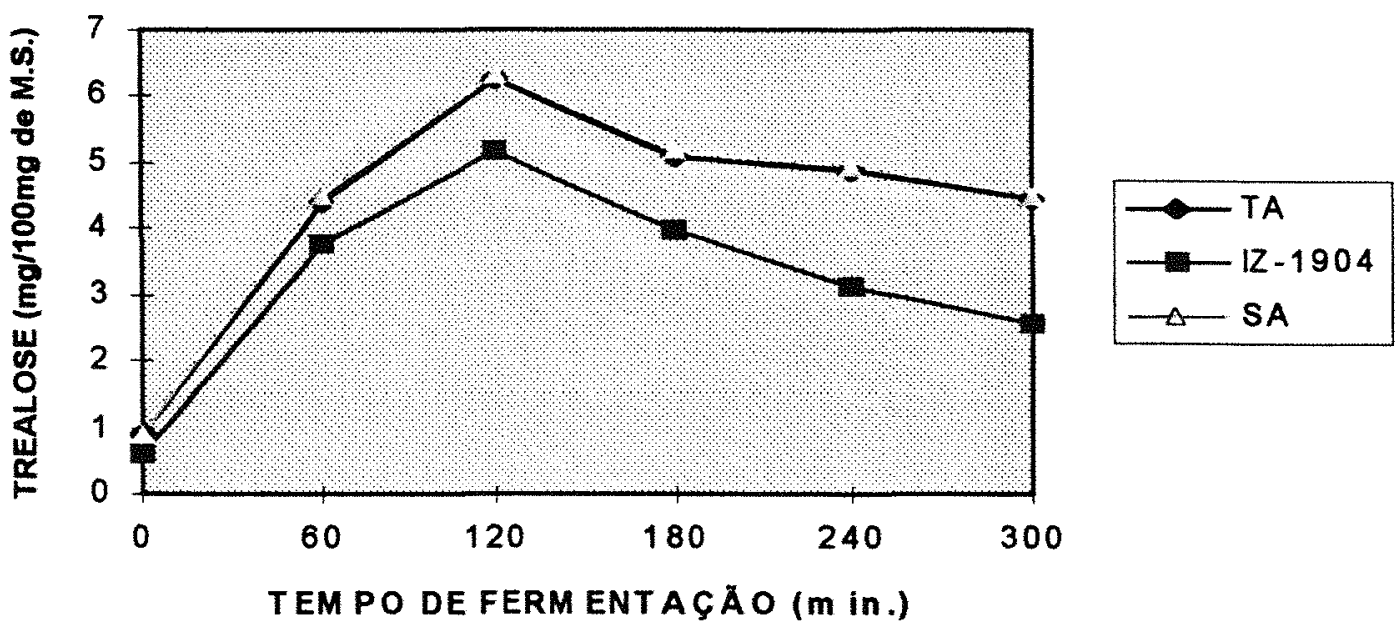

Figura 5: Acúmulo e degradação da trealose endógena das leveduras em função do tempo de fermentação 
Por este teste de fermentação observa-se que todas as leveduras iniciam a fermentação com um teor relativamente baixo de trealose endógena, a qual vai se acumulando durante o tempo de fermentação e atinge o pico após 120 minutos, a partir do qual vai diminuindo gradativamente.

Esta diminuição no teor de trealose endógena das leveduras possivelmente se deve ao seu consumo pela levedura, a fim de conseguir manter as suas funções vitais, devido ao esgotamento total da glicose do meio de fermentação.

\subsection{Efeito dos tratamentos na viabilidade das leveduras e na sua manutenção após liofilização}

Os resultados do teor de trealose endógena, da viabilidade inicial e aos 10,40 e 90 dias após a liofilização das levedura estudadas, submetidas aos diferentes tratamentos de acúmulo ou esgotamento da trealose endógena e crioprotetores, encontram-se nas Tabelas 2, 4 e 6 do Apêndice.

Os resultados da manutenção da viabilidade após 10,40 e 90 dias da liofilização das leveduras estudadas, submetidas aos diferentes tratamentos de acúmulo ou esgotamento da trealose endógena e crioprotetores, encontram-se nas Tabelas 3, 5 e 7 do Apêndice.

Nas Tabelas 8 a 18 do Apêndice são apresentadas as análises de variância com seus respectivos niveis de significância. De acordo com estas Tabelas, para todas as leveduras estudadas houve efeito significativo ao nivel de $1 \%$ entre teor de trealose endógena e manutenção da viabilidade aos 10 dias após liofilização para todos os tratamentos. Quanto à manutenção da viabilidade aos 10,40 e 90 dias após a liofilização, não houve diferença estatística ao nivel de $5 \%$, para todas as leveduras e tratamentos estudados.

Os valores médios do teor de trealose endógena, da viabilidade inicial e aos $10,40 \mathrm{e}$ 90 dias após a liofilização das leveduras estudadas, submetidas aos diferentes tratamentos de acúmulo ou esgotamento da trealose endógena e crioprotetores, encontram-se nas Figuras 6, 8 e 10 . 
Os valores médios da manutenção da viabilidade após 10,40 e 90 dias da liofilização das leveduras estudadas, submetidas aos diferentes tratamentos de acúmulo ou esgotamento da trealose endógena e crioprotetores, encontram-se na Tabela 1 e nas Figuras 7, 9 e 11.

Os valores médios da manutenção da viabilidade após 10,40 e 90 dias da liofilização das leveduras estudadas, submetidas a cada tratamento de acúmulo ou esgotamento da trealose endógena e crioprotetor, encontram-se nas Figuras 12 a 17.

De uma forma geral, os resultados obtidos mostraram uma grande variação em relação à manutenção da viabilidade celular após a liofilização das leveduras frente aos tratamentos testados.

\subsubsection{Levedura TA}

Os resultados apresentados na Tabela 2 do Apêndice e na Figura 6 mostram que a levedura TA submetida ao tratamento de esgotamento da trealose endógena, tendo a solução de leite desnatado como crioprotetor para a liofilização, apresentou um teor de $0,85 \%$ de trealose endógena, com 99,13\% de viabilidade inicial, 30,50\% de viabilidade após 10 dias da liofilização, $28,99 \%$ após 40 dias e $28,25 \%$ após 90 dias. Portanto, através dos resultados apresentados na Tabela 3 do Apêndice e nas nas Figuras 7 e 12, observa-se que houve uma manutenção de $31,04 \%$ da sua viabilidade após 10 dias da liofilização, de $29,24 \%$ após 40 dias e $28,50 \%$ após 90 dias.

De acordo com os resultados apresentados na Tabela 2 do Apêndice e na Figura 6 observa-se que a levedura TA submetida ao tratamento de esgotamento da trealose endógena, tendo a solução de sacarose como crioprotetor para a liofilização, apresentou um teor de $0,84 \%$ de trealose endógena, com $99,00 \%$ de viabilidade inicial, $20,89 \%$ de viabilidade após 10 dias da liofilização, $19,00 \%$ após 40 dias e $18,36 \%$ após 90 dias. Portanto, pelos resultados apresentados na Tabela 3 do Apêndice e nas Figuras 7 e 13 verifica-se que houve uma manutenção de $21,11 \%$ da sua viabilidade após 10 dias da liofilização, de 19,20\% após 40 dias e $18,55 \%$ após 90 dias. 
Através dos resultados apresentados na Tabela 2 do Apêndice e na Figura 6 verificase que a levedura TA submetida ao tratamento de esgotamento da trealose endógena, tendo a solução de trealose como crioprotetor para a liofilização, apresentou um teor de $0,85 \%$ de trealose endógena, com $98,87 \%$ de viabilidade inicial, $26,85 \%$ de viabilidade após 10 dias da liofilização, 25,65\% após 40 dias e $24,00 \%$ após 90 dias. Portanto, de acordo com os resultados apresentados na Tabela 3 do Apêndice e nas Figuras 7 e 14, nota-se que houve uma manutenção de $27,15 \%$ da sua viabilidade após 10 dias da liofilização, de $25,94 \%$ após 40 dias e $24,27 \%$ após 90 dias.

Pelos resultados apresentados na Tabela 2 do Apêndice e na Figura 6 observa-se que a levedura TA submetida ao tratamento de acúmulo da trealose endógena, tendo a solução de leite desnatado como crioprotetor para a liofilização, apresentou um teor de 6,39\% de trealose endógena, com $93,30 \%$ de viabilidade inicial, $54,96 \%$ de viabilidade após 10 dias da liofilização, 52,66\% após 40 dias e $51,13 \%$ após 90 dias. Portanto, através dos resultados apresentados na Tabela 3 do Apêndice e nas Figuras 7 e 15, verifica-se que houve uma manutenção de $58,92 \%$ da sua viabilidade após 10 dias da liofilização, de $56,44 \%$ após 40 dias e $54,81 \%$ após 90 dias.

Os resultados apresentados na Tabela 2 do Apêndice e na Figura 6 mostram que a levedura TA submetida ao tratamento de acúmulo da trealose endógena, tendo a solução de sacarose como crioprotetor para a liofilização, apresentou um teor de $6,36 \%$ de trealose endógena com 93,54\% de viabilidade inicial, 33,79\% de viabilidade após 10 dias da liofilização, $31,19 \%$ após 40 dias e $30,60 \%$ após 90 dias. Portanto, de acordo com os resultados apresentados na Tabela 3 do Apêndice e nas Figuras 7 e 16, observa-se que houve uma manutenção de $36,12 \%$ da sua viabilidade após 10 dias da liofilização, de $33,34 \%$ após 40 dias e $32,71 \%$ após 90 dias.

Através dos resultados apresentados na Tabela 2 do Apêndice e na Figura 6 observase que a levedura TA submetida ao tratamento de acúmulo da trealose endógena, tendo a solução de trealose como crioprotetor para a liofilização, apresentou um teor de $6,24 \%$ de trealose endógena, com $93,56 \%$ de viabilidade inicial, $40,75 \%$ de viabilidade após 10 dias da liofilização, 38,07\% após 40 dias e 38,06\% após 90 dias. Portanto, pelos resultados 
apresentados na Tabela 3 do Apêndice e nas Figuras 7 e 17, nota-se que houve uma manutenção de $43,56 \%$ da sua viabilidade após 10 dias da liofilização, de 40,69\% após 40 dias e $40,68 \%$ após 90 dias. 


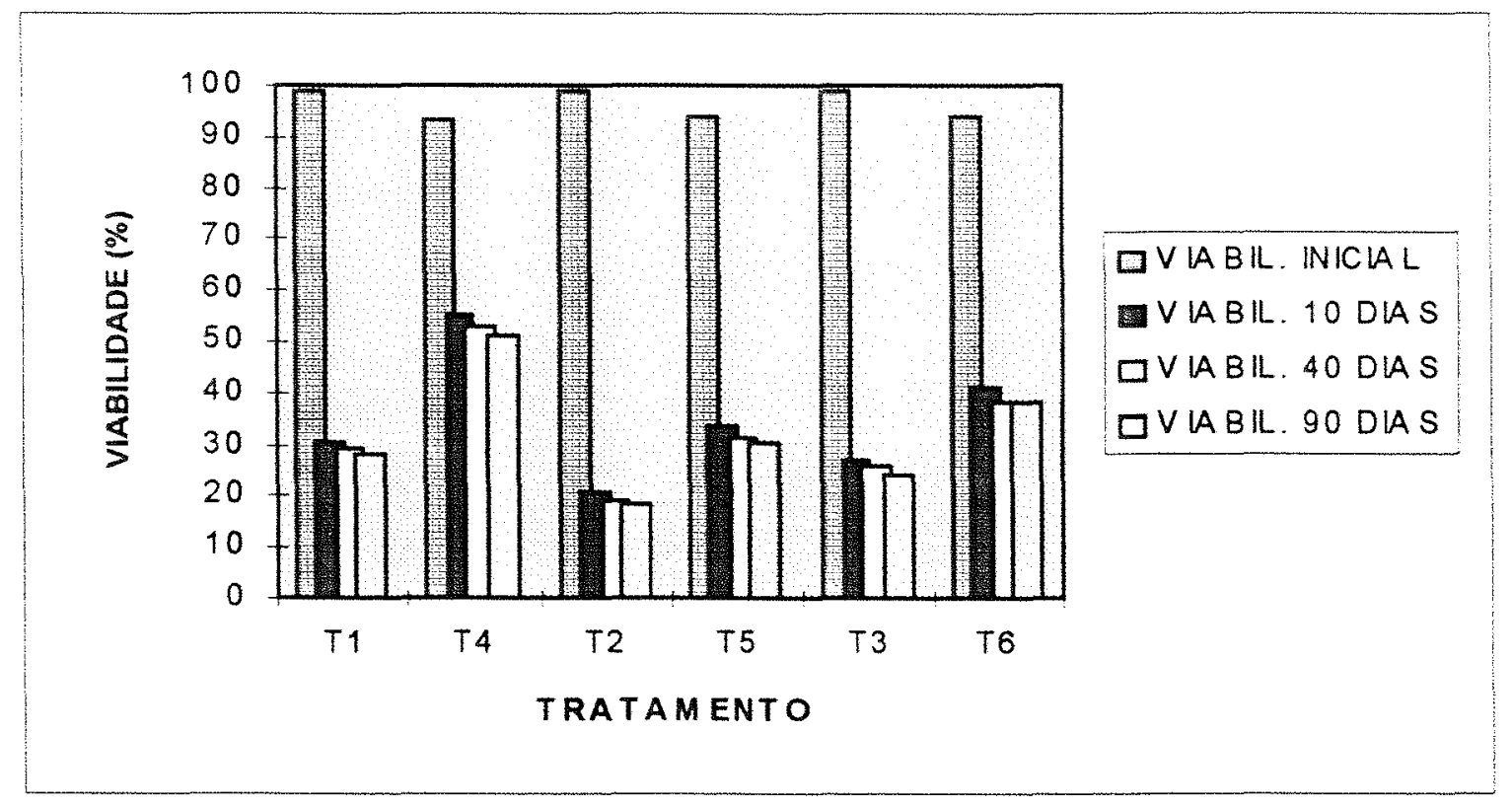

Figura 6: Efeito dos tratamentos no comportamento da viabilidade da levedura TA após liofilização.
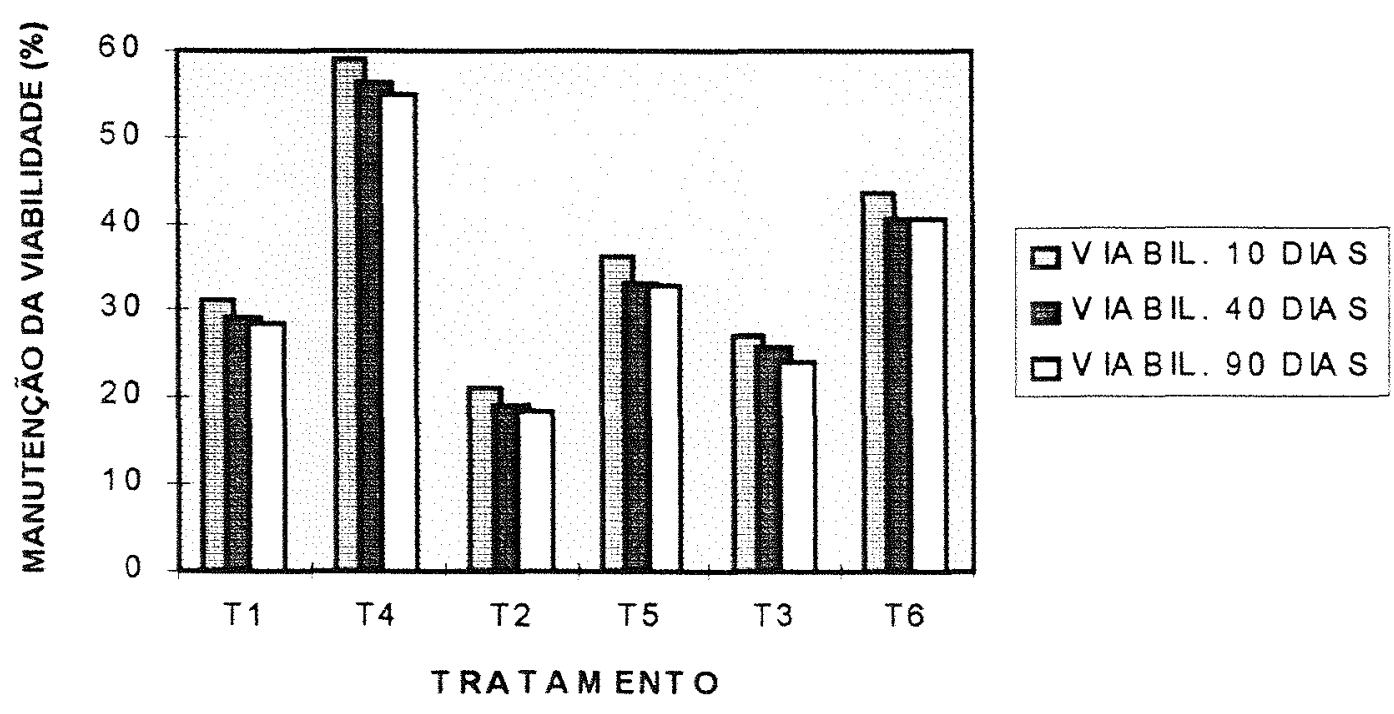

: $V I A B I L .40$ DIAS

QVIABIL. 90 DIAS

Figura 7: Efeito dos tratamentos na manutenção da viabilidade da levedura TA após liofilização. 


\subsubsection{Levedura IZ-1904}

Os resultados apresentados na Tabela 4 do Apêndice e na Figura 8 mostram que a levedura IZ-1904 submetida ao tratamento de esgotamento da trealose endógena, tendo a solução de leite desnatado como crioprotetor para a liofilização, apresentou um teor de $0,64 \%$ de trealose endógena, com $95,72 \%$ de viabilidade inicial, $27,12 \%$ de viabilidade após 10 dias da liofilização, 25,91\% após 40 dias e $25,14 \%$ após 90 dias. Portanto, através dos resultados apresentados na Tabela 5 do Apêndice e nas Figuras 9 e 12, observa-se que houve uma manutenção de $28,29 \%$ da sua viabilidade após 10 dias da liofilização, de $27,07 \%$ após 40 dias e $26,26 \%$ após 90 dias.

De acordo com os resultados apresentados na Tabela 4 do Apêndice e na Figura 8 observa-se que a levedura IZ-1904 submetida ao tratamento de esgotamento da trealose endógena, tendo a solução de sacarose como crioprotetor para a liofilização, apresentou um teor de $0,63 \%$ de trealose endógena, com $96,03 \%$ de viabilidade inicial, $18,01 \%$ de viabilidade após 10 dias da liofilização, 17,24\% após 40 dias e 16,61\% após 90 dias. Portanto, pelos

resultados apresentados na Tabela 5 do Apêndice e nas Figuras 9 e 13, verifica-se que houve uma manutenção de $18,75 \%$ da sua viabilidade após 10 dias da liofilização, de 17,95\% após 40 dias e $17,30 \%$ após 90 dias.

Através dos resultados apresentados na Tabela 4 do Apêndice e na Figura 8 verificase que a levedura IZ-1904 submetida ao tratamento de esgotamento da trealose endógena, tendo a solução de trealose como crioprotetor para a liofilização, apresentou um teor de $0,65 \%$ de trealose endógena, com $96,24 \%$ de viabilidade inicial, $23,02 \%$ de viabilidade após 10 dias da liofilização, $21,40 \%$ após 40 dias e $21,01 \%$ após 90 dias. Portanto, de acordo com os resultados apresentados na Tabela 5 do Apêndice e nas Figuras 9 e 14, nota-se que houve uma manutenção de $23,91 \%$ da sua viabilidade após 10 dias da liofilização, de $22,23 \%$ após 40 dias e $21,82 \%$ após 90 dias.

Pelos resultados apresentados na Tabela 4 do Apêndice e na Figura 8 observa-se que a levedura IZ-1904 submetida ao tratamento de acúmulo da trealose endógena, tendo a solução de leite desnatado como crioprotetor para a liofilização, apresentou um teor de 5,15\% 
de trealose endógena, com $90,36 \%$ de viabilidade inicial, $48,08 \%$ de viabilidade após 10 dias da liofilização, $46,22 \%$ após 40 dias e $45,36 \%$ após 90 dias. Portanto, através dos resultados apresentados na Tabela 5 do Apêndice e nas Figuras 9 e 15, verifica-se que houve uma manutenção de $53,38 \%$ da sua viabilidade após 10 dias da liofilização, de $51,32 \%$ após 40 dias e $50,36 \%$ após 90 dias.

Os resultados apresentados na Tabela 4 do Apêndice e na Figura 8 mostram que a levedura IZ-1904 submetida ao tratamento de acúmulo da trealose endógena, tendo a solução de sacarose como crioprotetor para a liofilização, apresentou um teor de $5,21 \%$ de trealose endógena, com $90,14 \%$ de viabilidade inicial, $30,11 \%$ de viabilidade após 10 dias da liofilização, $28,57 \%$ após 40 dias e $27,70 \%$ após 90 dias. Portanto, de acordo com os resultados apresentados na Tabela 5 do Apêndice e nas Figuras 9 e 16, observa-se que houve uma manutenção de $33,41 \%$ da sua viabilidade após 10 dias da liofilização, de $31,70 \%$ após 40 dias e $30,73 \%$ após 90 dias.

Através dos resultados apresentados na Tabela 4 do Apêndice e na Figura 8 observase que a levedura IZ-1904 submetida ao tratamento de acúmulo da trealose endógena, tendo a solução de trealose como crioprotetor para a liofilização, apresentou um teor de 5,08\% de trealose endógena, com $90,07 \%$ de viabilidade inicial, $37,96 \%$ de viabilidade após 10 dias da liofilização, 35,17\% após 40 dias e $34,47 \%$ após 90 dias. Portanto, pelos resultados apresentados na Tabela 5 do Apêndice e nas Figuras 9 e 17, nota-se que houve uma manutenção de $42,02 \%$ da sua viabilidade após 10 dias da liofilização, de $38,94 \%$ após 40 dias e $38,16 \%$ após 90 dias. 


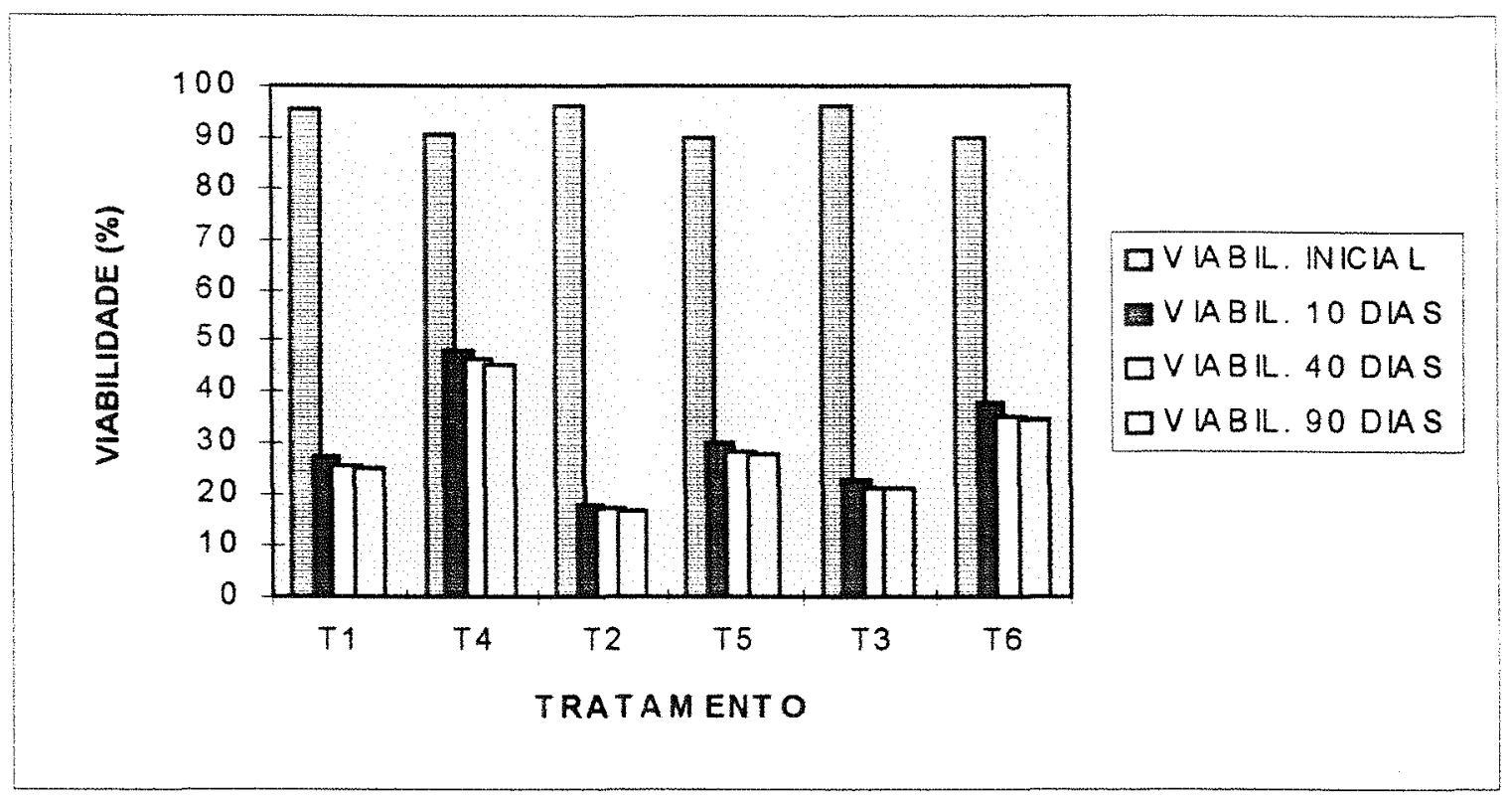

Figura 8: Efeito dos tratamentos no comportamento da viabilidade da levedura IZ-1904 após liofilização.
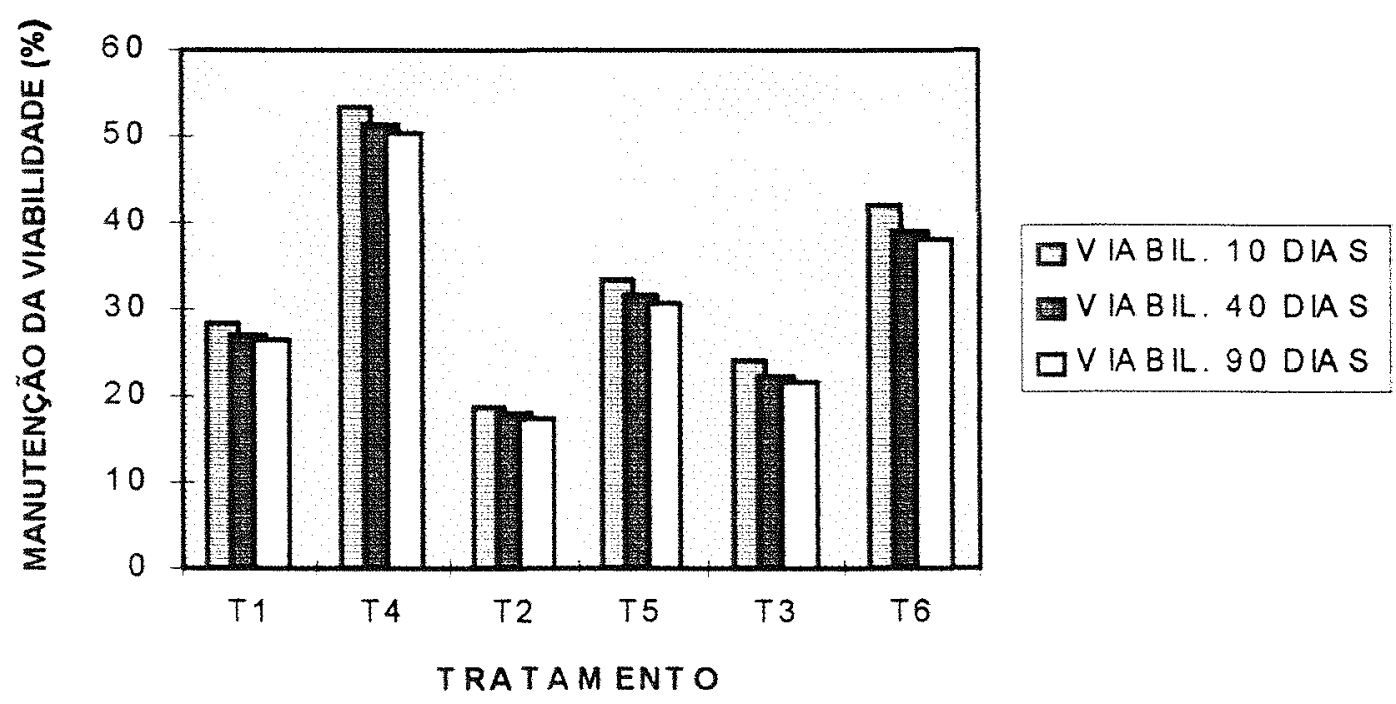

Figura 9: Efeito dos tratamentos na manutenção da viabilidade da levedura IZ-1904 após liofilização. 


\subsubsection{Levedura SA}

Os resultados apresentados na Tabela 6 e na Figura 10 mostram que a levedura SA submetida ao tratamento de esgotamento da trealose endógena, tendo a solução de leite desnatado como crioprotetor para a liofilização, apresentou um teor de $0,83 \%$ de trealose endógena, com 99,32\% de viabilidade inicial, 32,57\% de viabilidade após 10 dias da liofilização, 30,87\% após 40 dias e 30,63\% após 90 dias. Portanto, através dos resultados apresentados na Tabela 7 e nas Figuras 11 e 12, observa-se que houve uma manutenção de $32,80 \%$ da sua viabilidade após 10 dias da liofilização, de $31,09 \%$ após 40 dias e $30,85 \%$ após 90 dias.

De acordo com os resultados apresentados na Tabela 6 e na Figura 10 observa-se que a levedura SA submetida ao tratamento de esgotamento da trealose endógena, tendo a solução de sacarose como crioprotetor para a liofilização, apresentou um teor de $0,80 \%$ de trealose endógena, com 99,16\% de viabilidade inicial, $21,67 \%$ de viabilidade após 10 dias da liofilização, 20,26\% após 40 dias e 19,93\% após 90 dias. Portanto, pelos resultados

apresentados na Tabela 7 e nas Figuras 11 e 13, verifica-se que houve uma manutenção de $21,86 \%$ da sua viabilidade após 10 dias da liofilização, de $20,43 \%$ após 40 dias e $20,10 \%$ após 90 dias.

Através dos resultados apresentados na Tabela 6 e na Figura 10 verifica-se que a levedura SA submetida ao tratamento de esgotamento da trealose endógena, tendo a solução de trealose como crioprotetor para a liofilização, apresentou um teor de $0,81 \%$ de trealose endógena, com $99,02 \%$ de viabilidade inicial, $27,98 \%$ de viabilidade após 10 dias da liofilização, 26,25\% após 40 dias e $25,17 \%$ após 90 dias. Portanto, de acordo com os resultados apresentados na Tabela 7 e nas Figuras 11 e 14, nota-se que houve uma manutenção de $28,25 \%$ da sua viabilidade após 10 dias da liofilização, de $26,50 \%$ após 40 dias e $25,42 \%$ após 90 dias.

Pelos resultados apresentados na Tabela 6 e na Figura 10 observa-se que a levedura SA submetida ao tratamento de acúmulo da trealose endógena, tendo a solução de leite desnatado como crioprotetor para a liofilização, apresentou um teor de $6,12 \%$ de trealose 
endógena, com 93,89\% de viabilidade inicial, 56,01\% de viabilidade após 10 dias da liofilização, $53,48 \%$ após 40 dias e $52,53 \%$ após 90 dias. Portanto, através dos resultados apresentados na Tabela 7 e nas Figuras 11 e 15, verifica-se que houve uma manutenção de $59,62 \%$ da sua viabilidade após 10 dias da liofilização, de $56,95 \%$ após 40 dias e $55,95 \%$ após 90 dias.

Os resultados apresentados na Tabela 6 e na Figura 10 mostram que a levedura SA submetida ao tratamento de acúmulo da trealose endógena, tendo a solução de sacarose como crioprotetor para a liofilização, apresentou um teor de 6,34\% de trealose endógena, com $93,48 \%$ de viabilidade inicial, $35,02 \%$ de viabilidade após 10 dias da liofilização, 33,06\% após 40 dias e 32,31\% após 90 dias. Portanto, de acordo com os resultados apresentados na Tabela 7 e nas Figuras 11 e 16, observa-se que houve uma manutenção de $37,46 \%$ da sua viabilidade após 10 dias da liofilização, de $35,36 \%$ após 40 dias e $34,55 \%$ após 90 dias.

Através dos resultados apresentados na Tabela 6 e na Figura 10 observa-se que a levedura SA submetida ao tratamento de acúmulo da trealose endógena, tendo a solução de trealose como crioprotetor para a liofilização, apresentou um teor de $6,25 \%$ de trealose endógena, com $93,55 \%$ de viabilidade inicial, $41,82 \%$ de viabilidade após 10 dias da liofilização, 40,01\% após 40 dias e $38,91 \%$ após 90 dias. Portanto, pelos resultados apresentados na Tabela 7 e nas Figuras 11 e 17, nota-se que houve uma manutenção de $44,72 \%$ da sua viabilidade após 10 dias da liofilização, de $42,79 \%$ após 40 dias e $41,61 \%$ após 90 dias. 


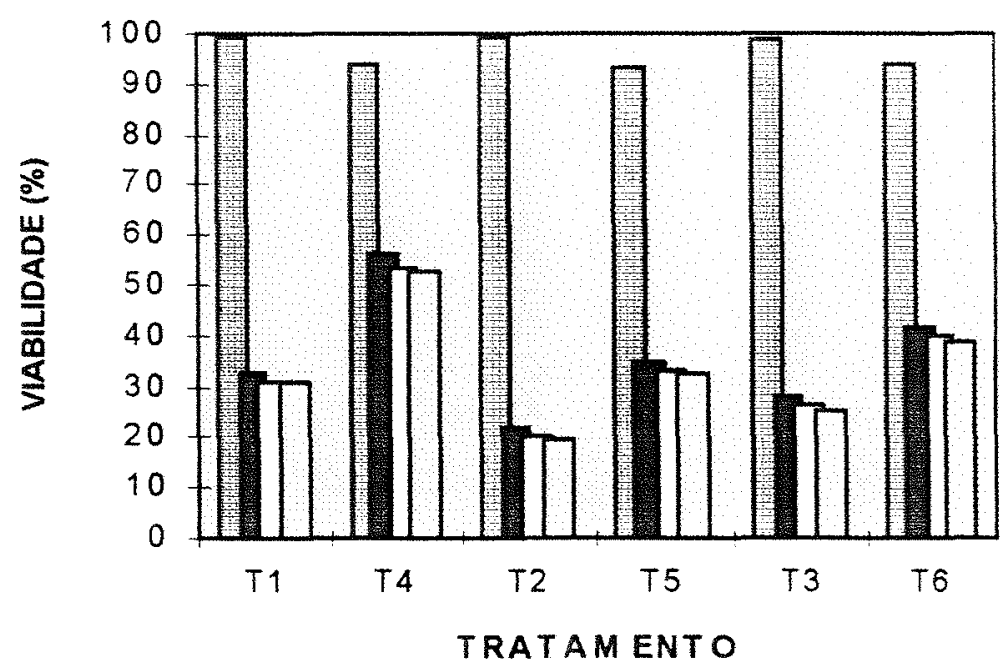

DVIABIL. INICIAL VIABIL. 10 DIAS $\square \vee I A B I L .40$ DIAS DVIABIL, 90 DIAS

Figura 10: Efeito dos tratamentos no comportamento da viabilidade da levedura SA após liofilização.

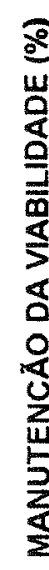

60

50

商 40

30

造 20

$\sum_{2}^{\uplus} 10$

0

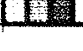

T1

T

RATAM ENTO

Figura 11: Efeito dos tratamentos na manutenção da viabilidade da levedura SA após liofilização. 
Dentre as três leveduras testadas, as leveduras TA e SA não diferiram entre si na capacidade de acumular trealose endógena, porém diferiram estatisticamente ao nível de $1 \%$ da levedura IZ-1904. Assim sendo, as leveduras TA e SA apresentaram uma maior capacidade de acúmulo de trealose endógena que a levedura IZ-1904. Por consequência disto, em todos os tratamentos testados, as leveduras TA e SA apresentaram também maior taxa de manutenção da viabilidade celular após a liofilização, sem no entanto diferirem estatisticamente, ao nivel de 5\%, da levedura IZ-1904.

Nas Figuras 12 a 17 são mostrados os valores médios da manutenção da viabilidade após 10, 40 e 90 dias da liofilização das leveduras estudadas, submetidas a cada tratamento de acúmulo ou esgotamento da trealose endógena e crioprotetor.

Uma visão geral da ação dos diferentes tratamentos utilizados no presente trabalho sobre a manutenção da viabilidade celular aos 10,40 e 90 dias após a liofilização de todas leveduras testadas, encontra-se na Tabela 1. 


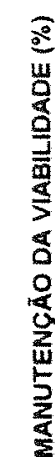

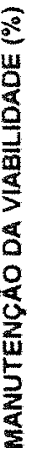
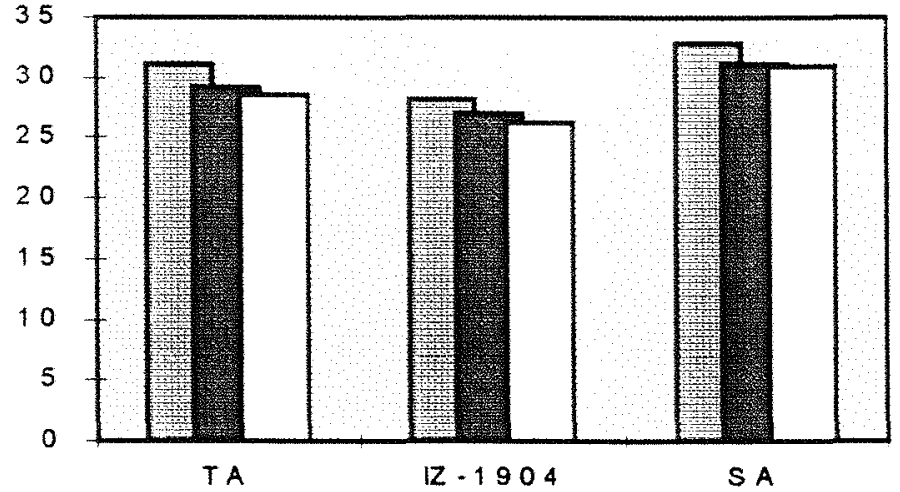

OVIA BIL. 10 DIAS

IAS BIL. 40 DIAS

$\square \vee I A B I L .90$ DIA S

LEVEDURA

Figura 12: Efeito do tratamento esgotamento da trealose endógena, tendo a solução de leite desnatado como crioprotetor para a liofilização, na manutenção da viabilidade das leveduras após liofilização.
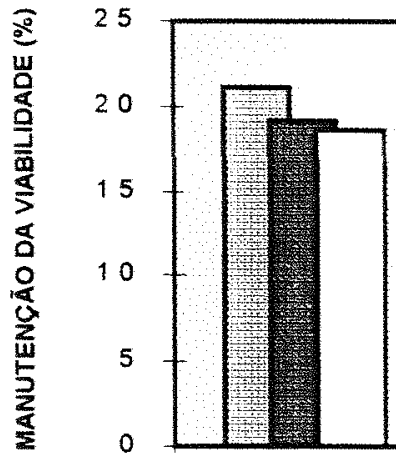

T A

S A

L EV EDURA

Figura 13: Efeito do tratamento esgotamento da trealose endógena, tendo a solução de sacarose como crioprotetor para a liofilização, na manutenção da viabilidade das leveduras após liofilização. 


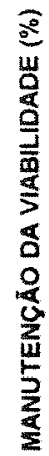
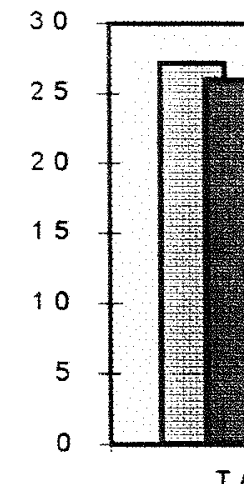

T A

IZ -1904

LEVEDURA

Figura 14: Efeito do tratamento esgotamento da trealose endógena, tendo a solução de trealose como crioprotetor para a liofilização, na manutenção da viabilidade das leveduras após liofilização.

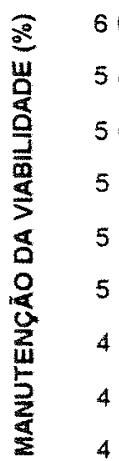

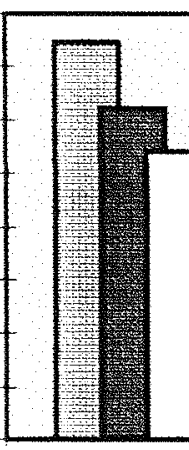

TA

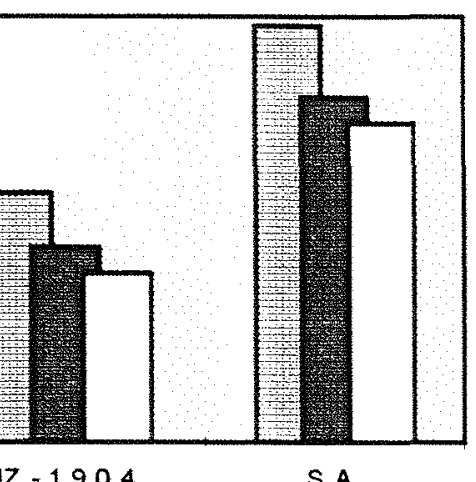

GVIA BIL. 10 DIA S

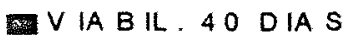

$\square \vee I A B I L .90$ DIAS

Figura 15: Efeito do tratamento acúmulo da trealose endógena, tendo a solução de leite desnatado como crioprotetor para a liofilização, na manutenção da viabilidade das leveduras após liofilização. 


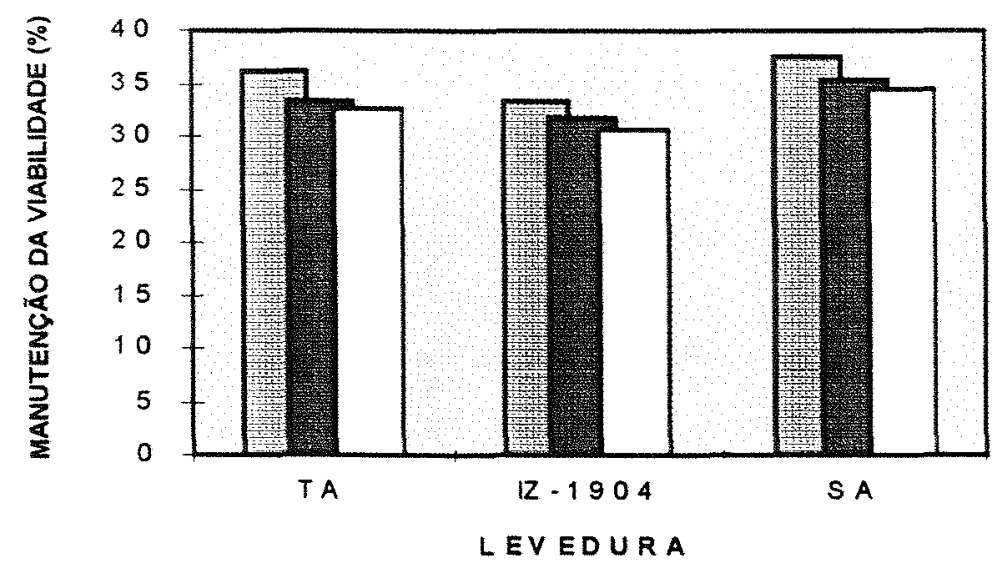

DVIABIL. 10 DIAS

DIABIL. 40 DIAS

DVIABIL. 90 DIAS

Figura 16: Efeito do tratamento acúmulo da trealose endógena, tendo a solução de sacarose como crioprotetor para a liofilização, na manutenção da viabilidade das leveduras após liofilização.

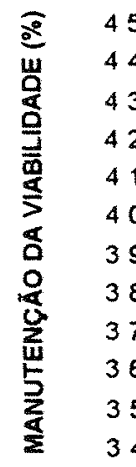

5
4
3
2
1
0
9
8
7
6
5
4

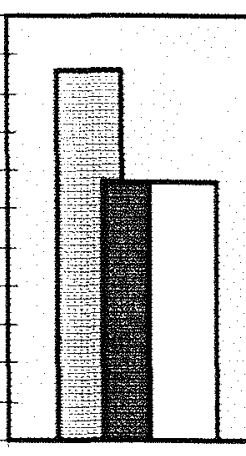

T A

LEVEDURA

Figura 17: Efeito do tratamento acúmulo da trealose endógena, tendo a solução de trealose como crioprotetor para a liofilização, na manutenção da viabilidade das leveduras após liofilização. 
Tabela 1: Ação dos diferentes tratamentos testados sobre a manutenção da viabilidade celular aos 10, 40 e 90 dias após a liofilização das leveduras utilizadas.

\begin{tabular}{|c|c|c|c|c|}
\hline \multirow[b]{2}{*}{ TRATAMENTO } & \multirow[b]{2}{*}{$\begin{array}{l}\text { MANUTENCCAO DA } \\
\text { VIABILIDADE (\%) }\end{array}$} & \multicolumn{3}{|c|}{ LEVEDURA } \\
\hline & & TA & IZ-1904 & $\mathrm{SA}$ \\
\hline \multirow{3}{*}{$\mathrm{Tl}$} & AOS 10 DIAS & 31.04 & 28,29 & 32,80 \\
\hline & AOS 40 DIAS & 29,24 & 27,07 & 31,09 \\
\hline & AOS 90 DIAS & 28.50 & 26,26 & 30,85 \\
\hline \multirow{3}{*}{$\mathrm{T} 2$} & AOS 10 DIAS & 21.11 & 18,75 & 21.86 \\
\hline & AOS 40 DIAS & 19,20 & 17,95 & 20,43 \\
\hline & AOS 90 DLAS & 18,55 & 17,30 & 20,10 \\
\hline \multirow{3}{*}{ T3 } & AOS 10 DIAS & 27,15 & 23,91 & 28,25 \\
\hline & AOS 40 DIAS & 25,94 & 22,23 & 26,50 \\
\hline & AOS 90 DIAS & 24,27 & 21,82 & 25,42 \\
\hline \multirow{3}{*}{$\mathrm{T} 4$} & AOS 10 DIAS & 58,92 & 53,38 & 59.62 \\
\hline & AOS 40 DIAS & 56,44 & 51,32 & 56,95 \\
\hline & AOS 90 DIAS & 54.81 & 50,36 & 55,95 \\
\hline \multirow{3}{*}{ T5 } & AOS 10 DIAS & 36.12 & 33,41 & 37,46 \\
\hline & AOS 40 DIAS & 33.34 & 31,70 & 35,36 \\
\hline & AOS 90 DIAS & 32,71 & 30,73 & 34.55 \\
\hline \multirow{3}{*}{ T6 } & AOS 10 DIAS & $+3,56$ & 42,02 & 44,72 \\
\hline & AOS 40 DIAS & $+0,69$ & 38,94 & 42,79 \\
\hline & AOS 90 DIAS & +0.68 & 38,16 & 41,61 \\
\hline
\end{tabular}




\section{DISCUSSÃO}

Nas condições da presente pesquisa observa-se que houve o acúmulo da trealose endógena pelas leveduras com a aplicação de um tratamento térmico (mudança da temperatura do meio de 26 para $45^{\circ} \mathrm{C}$ por duas horas), sendo que, com este tratamento, a trealose endógena da levedura TA passou, em média, de 0,85 para $6,33 \%$, da levedura $\mathrm{LZ}$ 1904 de 0,64 para $5,15 \%$ e da levedura SA de 0,81 para $6,24 \%$. Estes resultados estão de acordo com Grba et alii (1975), Attfield (1987), Hottinger (1987a,b; 1992), Eleutherio et alii (1993a), Penna \& Fernandes (1994) e Ribeiro et alii (1994) os quais citam que, quando as

células de levedura são expostas a um tratamento térmico (mudança de $23-30$ para $36-45^{\circ} \mathrm{C}$ ), há um acúmulo de trealose endógena nas células.

Pelos resultados da presente pesquisa observa-se que com o acúmulo da trealose endógena houve um significativo aumento na manutenção da viabilidade após a liofilização das três leveduras testadas (TA, IZ-1904 e SA). Estes resultados estão de acordo com Suomalainen \& Pfaffli (1961) e Lillie \& Pringle (1980) os quais verificaram que a manutenção da viabilidade celular de leveduras por periodos de armazenamento prolongados é devida ao alto teor de trealose endógena. Estes resultados aqui encontrados também concordam com Hino et al (1990) e com Grba et al (1975) e Leslie et al (1994) os quais relatam que, com o acúmulo da trealose endógena das leveduras, aumenta-se a sua tolerância ao congelamento e à desidratação, respectivamente.

De acordo com os resultados do presente trabalho, tanto para o tratamento de acúmulo como para o de esgotamento da trealose endógena, a solução de leite desnatado a $10 \%$ foi a que proporcionou melhor crioproteção às células das três leveduras testadas, resultando em uma maior taxa de manutenção da viabilidade após a liofilização. A solução de 
sacarose a $10 \%$ foi a que proporcionou menor taxa de manutenção da viabilidade após a liofilização das três leveduras.

Os resultados de melhor crioproteção às células de levedura obtidos com o leite desnatado como crioprotetor para a liofilização podem ser explicados pela hipótese de que, por ser uma mistura de diversos componentes, algum ou alguns destes componentes do leite desnatado possam exercer uma melhor ação crioprotetora às células de levedura que a trealose ou a sacarose isoladamente.

Uma segunda hipótese seria que, sendo a lactose um carboidrato que a levedura não consome e a sacarose e a trealose carboidratos que a levedura pode consumir, a ressuspensão das células de levedura nos crioprotetores sacarose e trealose pode ter levado a uma alteração no seu teor de trealose acumulada endogenamente devido a uma mudança na concentração de açúcar aproveitável pela levedura no meio, pois, segundo Panek et alii (1975) e Lillie \& Pringle (1980), quando há açúcar aproveitável no meio, as leveduras, além de não acumularem trealose, podem esgotar a sua trealose endógena acumulada anteriormente.

Numa terceira hipótese, parte da trealose acumulada endogenamente poderia ter sido transportada para fora da célula e auxiliado o leite desnatado na crioproteção das células de levedura submetidas à liofilização. Esta hipótese parece ser aceitável pois Crowe et alii (1991) relata que a levedura Saccharomyces cerevisiae possui um carregador para que a trealose endógena possa ser transportada para fora da célula e Eleutherio et alii (1993b) cita que a trealose deve estar presente nos dois lados da camada de lipídios da membrana celular para oferecer proteção contra o estresse, sugerindo que o carregador desempenhe um papel crucial para a célula de levedura, transportando a trealose endógena para o exterior da célula.

Para todas as leveduras testadas, o tratamento que proporcionou uma maior manutenção da viabilidade, tanto aos 10,40 e 90 dias após a liofilização, foi o tratamento de acúmulo da trealose endógena tendo o leite desnatado como crioprotetor para a liofilização, com porcentagens de manutenção da viabilidade para a levedura TA de 58,92\%, 56,44\% e $54,81 \%$, respectivamente; para a levedura IZ-1904 de 53,38\%,51,32\% e 50,36\%, respectivamente; e para a levedura SA de $59,62 \%, 56,95 \%$ e $55,95 \%$, respectivamente. 
O tratamento que proporcionou uma menor manutenção da viabilidade das três leveduras testadas, tanto aos 10,40 e 90 dias após a liofilização, foi o tratamento de esgotamento da trealose endógena tendo a sacarose como crioprotetor para a liofilização, com porcentagens de manutenção da viabilidade para a levedura TA de $21,11 \%, 19,20 \% \mathrm{e}$ $18,55 \%$, respectivamente; para a levedura $1 Z-1904$ de 18,75\%, 17,95\% e 17,30\%, respectivamente; e para a levedura SA de $21,86 \%, 20,43 \%$ e $20,10 \%$, respectivamente.

Os resultados aqui encontrados de manutenção da viabilidade praticamente constantes até 90 dias após a liofilização estão de acordo com Costa \& Ferreira (1991) e Silva et al (1992b) os quais relatam que a liofilização mantém estável a viabilidade das culturas de levedura por longo periodo de estocagem. 


\section{CONCLUSÕES}

A análise dos resultados obtidos permite as seguintes conclusões:

6.1. O acúmulo da trealose endógena pelas leveduras proporcionou uma maior taxa de manutenção da viabilidade celular após o processo de conservação por liofilização.

6.2. Dentre os crioprotetores testados, a solução de leite desnatado a $10 \%$ foi o que proporcionou uma melhor crioproteção às células de levedura, obtendo-se maior viabilidade celular após a liofilização.

6.3. A viabilidade celular após a liofilização de todas as leveduras utilizadas manteve-se constante até 90 dias, o qual foi o prazo máximo testado.

6.4. Das leveduras testadas, as leveduras TA e SA possuiram maior capacidade de acumular trealose endógena através do tratamento térmico. 


\section{REFERÊNCIAS BIBLIOGRÁFICAS}

ALEXANDER, G.A. Improved lyophilization procedure for storage of reference cultures and clinical isolates. Journal of Clinical Microbiology, v. 13, p. 805-6, 1981.

ALTERTHUM, F.; CRUZ, M.R.M.G. Aumento do rendimento da fermentação alcoólica pela adição de óleo de soja. Revista de Microbiologia, v.18, n. 1, p. 52-7, 1987.

AMORIM, H.V.; OLIVEIRA, A.J.; BASSO, L.C.; GALlO, C.R. Processos de fermentação alcoólica, seu controle e monitoramento. Piracicaba: Centro de Biotecnologia Agrícola, 1989. 145p.

ANTHEUNISSE, J. Viability of lyophilized microorganisms after storage. Antonie van Leeuwenhoek, v.39, p. 243-8, 1973.

ANTHEUNISSE. H.; BRUIN-TOL, J.W.; WAN DER POL-VAN SOEST, M.E. Survival of microorganisms after drying and storage. Antonie van Leeuwenhoek, v.47, p. 53945,1981 .

ARGUELLES, J.C. Heat-shock response in a yeast tps1 mutant deficient in trehalose synthesis. FEBS Letters, v.350, n.2/3, p. 266-70, 1994. 
ARTHUR, H.; WATSON, K. Thermal adaptation in yeast: growth temperatures, membrane lipid and cytochrome composition of phychrophilic, mesophilic and thermophilic yeasts. Journal of Bacteriology, v.128, n.1, p. 56-68, 1976.

ASHWOOD-SMITH, M.J.; TREVINO, J.; WARBY, C. Effect of freezing on the molecular weight of bacterial DNA. Cryobiology, v.9, p. 141-3, 1972.

ATTFIELD, P.V. Trehalose accumulates in Saccharomyces cerevisiae during exposure to agents that induce heat shock response. FEBS Letters, v.225, n. 12, p. 259-63, 1987.

BARTON, J.K.; HOLLANDER, J.A.D.; HOPFIELD, J.J.; SHULMAN, R.G. ${ }^{13}$ C Nuclear magnetic resonance study of trehalose mobilization in yeast spores. Journal of Bacteriology, v.151, n. 1, p. 177-85, 1982.

BASSO, L.C.; AMORIM, H.V.; GUTIERREZ, L.E. Estudo comparativo entre os fermentos Fleischmann, IZ-1904 e M-300-A (TA). Relatório Anual de Pesquisas em Fermentação Alcoólica, Piracicaba: Fermentec/ESALQ/USP, v.8, p.44-7, 1988.

BASSO, L.C.; AMORIM, H.V. Estudo comparativo entre diferentes leveduras. Relatório Anual de Pesquisas em Fermentação Alcoólica, Piracicaba: Fermentec/ESALQ/USP, v.14, p.71-9, 1994.

BENEDICT, R.G.; SHARPE, E.S.; CORMAN, J.; MEYER, G.B.; BAER, E.F.; HALL, H.H.; JACKSON, R.W. Preservation of microorganisms by freeze drying. Applied Microbiology, v.9, p. 256-62, 1961.

BERNY, J.F.; HENNEBERT, G.L. Viability and stability of yeast cells and filamentous fungus spores during freeze-drying: effects of protectants and cooling rates. Mycologia, v. 83, n. 6, p. $805-15,1991$. 
BOSSIER, P.; FERNANDES, L.; MORGADO, C.; VILELA, C.; POUSADA, C.R. The molecular genetics of thermotolerance in yeast. Mededelingen Faculteit Landbonwkundige en Toegepaste Biologishe Wetenschappen Universiteit Gent, v.58, n.4b, p. 1911-9, 1993. /Resumo em AGRIS Abstracts on CD-ROM, v.6, 1993-95/.

BROWN, C.M; ROSE, A.H. Fatty-acid composition of Candida utilis as affected by growth temperature and dissolved-oxygen tension. Journal of Bacteriology, v.99, n..2, p.371-8, 1969.

CHANG, L.T; ELANDER, R.P. Long-term preservation of industrially important microorganisms. In: DEMAIN, A.L.; SOLOMON, N.A., ed. Manual of industrial microbiology and biotechnology. Washington, CRC Press, 1986. cap. 5, p. 49-55.

CHAVARRI, F.J.; PAZ, M; NUNEZ, M. Cryoprotective agents for frozen concentrated starters from nom bitter S. lactis strains. Biotechnology Letters, v. 10, p. 11-6, 1988.

COSTA, C.P.; FERREIRA, M.C. Preservação de microrganismos: revisão. Revista de Microbiologia, v.22, n.3, p. 263-8, 1991.

COUTINHO, C.; BERNARDES, E.; FÉLIX, D.; PANEK, A.D. Trehalose as cryoprotectant for preservation of yeast strains. Journal of Biotechnology, v. 7, p. 23-32, 1988.

CROWE, J.H.; CROWE, LM: CHAPMAN, D. Preservation of membranes in anhydrobiotic organisms. The role of trehalose. Science, v.223, p. 701-3, 1984a.

CROWE, L.M; MOURADIAN, R.; CROWE, J.H.; JACKSON, S.A; WOWOMERLEY, C. Effect of carbohydrates on membrane stability at low water activities. Biochimica et Biophysica Acta, v.769, p. 141-50, 1984 b. 
CROWE, J.H.; PANEK, A.D.; CROWE, L.M.; PANEK, A.C.; ARAÚJO, P.S. Trehalose transport in yeast cell. Biochemistry International, v.24, n.4, p. 721-30, 1991.

DALALY, B.K.; TAWFEEQ, M.S. Studies on low activity of baker's dry yeast upon storage. Iraqi Journal of Agricultural Sciences, v.5, n.1, p. 125-42, 1987. /Resumo em AGRIS Abstracts on CD-ROM, v.4, 1989-90/.

D'AMORE, T.; CRUMPLEN, R.; STEWART, G.G. The involvement of trehalose in yeast stress tolerance. Journal of Industrial Microbiology, v.7, n.3, p. 191-5, 1991.

DE VIRGILIO, C.; PIPER, P.; BOLLER, T.; WIEMKEN, A. Acquisicion of thermotolerance in Saccharomyces cerevisiae without heat shock protein HSP 104 and in the absence of protein synthesis. FEBS Letters, v.288, n. 1/2, p. 86-90, 1991.

DE VIRGILIO, C.; HOTTINGER, T.; DOMINGUEZ, J.; BOLLER, T.; WIEMKEN, A. The role of trehalose synthesis for the acquisition of thermotolerance in yeast: I. Genetic evidence that trehalose is a thermoprotectant. European Journal of Biochemistry, v. 219, n. $1 / 2$, p. $179-86,1994$.

DONNINI, C.; PUGLISI, P.P.; VECLI, A; MARMIROLI, N. Germination of Saccharomyces cerevisiae ascospores without trehalose mobilization as reveled by in vivo 13C nuclear magnetic resonance spectroscopy. Journal of Bacteriology, v.170, n.8, p. 3789-91, 1988.

ELEUTHERIO, E.C.A.; ARAÚJO, P.S.; PANEK, A.D. Protective role of trehalose during heat stress in Saccharomyces cerevisiae. Cryobiology, v.30, n.6, p. 591-6, 1993a. 
ELEUTHERIO, E.C.A.; ARAÚJO, P.S.; PANEK, A.D. Role of the trehalose carrier in dehydration resistance of Saccharomyces cerevisiae. Biochimica et Biophysica Acta, v.1156, p. 263-6, 1993b.

FARRANT, J;; WALTER, C.A.; LEE, H.; McGANN, L.E. Use of two-step cooling procedures to examine factors influencing cell survival following and thawing. Cryobiology, v.14, p. 273-86, 1977.

FARREL, J;; ROSE, A. Temperatures effect in microorganisms. Annual Review of Microbiology, v.21, p. 101-20, 1967.

GÉLINAS, P.; FISET, G.; LeDUY, A.; GOULET, J. Effect of growth conditions and trehalose content on cryotolerance of baker's yeast in frozen doughs. Applied and Environmental Microbiology, v.55, n.10, p. 2453-9, 1989.

GÉLINAS, P.; FISET, G.; WILLEMOT, C.; GOULET, J. Lipid content and cryotolerance of baker's yeast in frozen doughs. Applied and Environmental Microbiology, v.57, n.2, p. 463-8, 1991.

GRBA, S.; OURA, E.; SUOMALAINEN, H. On the formation of glycogen and trehalose in baker's yeast. European Journal of Applied Microbiology, v.2, p. 29-37, 1975.

GRIVELL, A.R; JACKSON, J.F. Microbial culture preservation with silica gel. Journal of General Microbiology, v.58, p. 423-5,1969.

GUERNA, R.L. Preservation. In: GERHARDT, P., ed. Manual of Methods for General Bacteriology. Washington, 1981. p. 208-17. 
GUTIERREZ, L.E. Estudo comparativo da fermentação alcoólica por linhagens de Saccharomyces cerevisiae e Saccharomyces uvarum. Piracicaba, 1989. 160p. Tese (Livre- Docência) - Escola Superior de Agricultura "Luiz de Queiroz", Universidade de São Paulo.

GUTIERREZ, L.E. Acúmulo de trealose em linhagens de Saccharomyces durante fermentação alcoólica. Anais da Escola Superior de Agricultura "Luiz de Queiroz", v. 47, n. 2 , p. $597-608,1990$.

GUTIERREZ, L.E. Changes in trehalose content of baker's yeast as affected by octanoic acid. Scientia Agricola, v. 50, n. 3, p. 460-3, 1993.

GUTIERREZ, L.E. Tópicos de bioquímica de leveduras. Piracicaba: NAPMA, 1994. $103 p$.

GUTIERREZ, L.E; ANNICCHINO, A.V.K.O; LUCATTI, L.; STIPP, J.M.S. Efeitos do ácido acético sobre a fermentação alcoólica. Arquivos de Biologia e Tecnologia, v.34, n.2, p. 235-42, 1991.

HECKLY, R.J.; QUAY, J. Brief review of lyophilization damage and repair in bacterial preparations. Cryobiology, v.18, p. 592-7, 1981.

HINO, A.; MIHARA, K.; NAKASHIMA, K.; TAKANO, H. Trehalose levels and survival ratio of freeze-tolerant versus freeze-sensitive yeasts. Applied and Environmental Microbiology, v.56, n.5, p. 1386-91, 1990.

HOTTINGER, T.; BOLLER, T.; WIEMKEN, A. Rapid changes of heat and desiccation tolerance correlated with changes of trehalose content in Saccharomyces cerevisiae cells subjected to temperature shifts. FEBS Letters, v.220, n.1, p. 113-5, 1987a. 
HOTTINGER, T.; SCHMUTZ, P.; WIEMKEN, A. Heat-induced accumulation and futile cycling of trehalose in Saccharomyces cerevisiae. Journal of Bacteriology, v.169, n.12, p. $5518-22,1987 \mathrm{~b}$.

HOTTINGER, T.; DE VIRGILIO, C.; BELL, W.; BOLLER, T.; WIEMKEN, A. The 70Kilodalton heat-shock proteins of the SSA subfamily negatively modulate heat-shockinduced accumulation of trehalose and promote recovery from heat stress in the yeast Saccharomyces cerevisiae. European Journal of Biochemistry, v.210, n.1, p. 125-32, 1992.

HOTTINGER, T.; DE VIRGILIO, C.; HALL, M.N.; BOLLER, T.; WIEMKEN, A. The role of trehalose synthesis for the acquisition of thermotolerance in yeast: II. Physiological concentrations of trehalose increase the thermal stability of proteins in vitro. European Journal of Biochemistry, v.219, n. 1/2, p. 187-93, 1994.

HUNTER, K.; ROSE, A.H. Lipid composition of Saccharomyces cerevisiae as influenced by growth temperature. Biochimica et Biophysica Acta, v.260, p. 639-53, 1972.

KELLER, F.; SCHELLEMBERG, M.; WIEMKEN, A. Localization of trehalase in vacuoles and of trehalose in the cytosol of yeast (Saccharomyces cerevisiae). Archives of Microbiology, v.131, p. 198-301, 1982.

KIRSOP, B.E. Maintenance of yeasts. In: KIRSOP, B.E.; SNELL, J.J.S., ed. Maintenance of microorganisms. London: Academic Press, 1984. cap. 12, p. 109-30.

KOCK, E.M; KOCK, F.C. Presence du trehalose dans la levure. Science, v.61, p. 570-2, 1925. 
KRATOCHVÍLOVÁ-KOCKOVÁ, A.; HUBÁLEK, Z. Liquid nitrogen storage of yeast cultures. II. Stability of characteristics of stored strains. Antonie van Leeuwenhoek, v. 49, p. $571-8,1983$.

KUPLESHAYA, M.B. Results of storing lyophilized cultures of microorganisms for 25 years. Mikrobiologiya, v.56, p. 488-91, 1987.

LEAPER, S; BLOOR, K. A note on the effect of storage on the chemical resistance of spores of Bacillus subtilis SA 22 and Bacillus subtilis globigii B 17. Journal of Applied Bacteriology, v.64, p. 183-6, 1988.

LESLIE, S.B.; TETER, S.A.; CROWE, L.M.; CROWE, J.H. Trehalose lowers membrane phase transitions in dry yeast cells. Biochimica et Biophysica Acta, v.1192, n.1, p. 7-13, 1994.

LEWIS, J.G.; LEARMONTH, R.P.; WATSON, K. Role of growth phase and ethanol in freeze-thaw stress resistance of Saccharomyces cerevisiae. Applied and Environmental Microbiology, v.59, n.4, p. 1065-71, 1993.

LEWIS, J.G.; LEARMONTH, R.P.; WATSON, K. Cryoprotection of yeast by alcohols during rapid freezing. Cryobiology, v.31, n.2, p. 193-8, 1994.

LILLIE, S.H.; PRINGLE, J.R. Reserve carbohydrate metabolism in Saccharomyces cerevisiae; responses to nutrient limitation. Journal of Bacteriology, v. 143, p. 1384-94, 1980.

LOW, C.; PARKS, L.W. Sterol and phospholipid acyl chain alterations in Saccharomyces cerevisiae secretion mutants as a function of temperature stress. Lipids, v.22, n.10, p. 715-20, 1987. 
LUDLAM, H.A; NWACHUKWU, B.; NOBLE, W.C.; SWAN, A.V; PHILLIPS, I. The preservation of microorganisms in biological specimens stored at $-70^{\circ} \mathrm{C}$. Journal of Applied Bacteriology, v.67, p. 417-23, 1989.

MACKENZIE, K.F.; SINGH, K.K.; BROWN, A.D. Water stress plating hypersensitivity of yeasts: protective role of trehalose in Saccharomyces cerevisiae. Journal of General Microbiology, v.134, p. 1661-6. 1988.

MAGER, W.H.; VARELA, J.C.S. Osmostress response of the yeast Saccharomyces. Molecular Microbiology, v.10, n.2, p. 253-8, 1993. /Resumo em BIOSIS Abstracts on CD-ROM, v. 1, 1995/.

MAIA, A.B.R.A.; NELSON, D.L. Protection of the intracellular trehalose content by com and soy flours in alcohol fermentation. Biotechnology Letters, v.15, n.7, p. 715-20, 1993.

MALIK, K.A. Freeze-drying of microorganisms using a simple apparatus. World Journal of Microbiology and Biotechnology, v.8, p. 76-9, 1992.

MANSURE, J.J.C.; PANEK, A.D.; CROWE, L.M.; CROWE, J.H. Trehalose inhibits ethanol effects on intact yeast cells and lipossomes. Biochimica et Biophysica Acta, v.1191, n.2, p. 309-16, 1994.

MERYMAN, H.T.; WILLIAMS, RJ.; DOUGLAS, M.S.J. Freezing injury from solution effect and its prevent by natural or artificial cryoprotection. Cryobiology, v.14, p. 287 $302,1977$. 
MISHRA, P.; PRASAD, R. Relationship between ethanol tolerance and fatty acid composition of Saccharomyces cerevisiae. Applied Microbiology and Biotechnology, v.30, p. 294-8, 1989.

MUGNUIER, J.; JUNG, G. Survival of bacteria and fungi in relation to water activity and the solvent properties of water in biopolymer gels. Applied and Environmental Microbiology, v.50, p. 108-14, 1985.

NWAKA, S.; KOPP, M.; BURGERT, M.; DEUCHLER, I.; KIENLE, I.; HOLZER, H. IS thermotolerance of yeast dependent on trehalose accumulation? FEBS Letters, v.344, n.2/3, p. $225-8,1994$.

PANEK, A.C.; BERNARDES, E.; PANEK, A.D. Does trehalose play a role in yeast cells under stress? In: LEOPOLD, A.C., ed. Membranes, metabolism and dry organisms. New York: Comstock Publishing Associates, 1987. cap. 7, p. 123-42.

PANEK, A.C.; MANSURE, J.J.C.; PASCHOALIN, M.F.; PANEK, A.D. Regulation of trehalose metabolism in Saccharomyces cerevisiae mutants during temperature shifts. Biochimie, v.72, p. 77-9, 1990.

PANEK, A.D. Synthesis of trehalose by baker's yeast (Saccharomyces cerevisiae). Archives of Biochemistry and Biophysics, v.98, p. 349-55, 1962.

PANEK, A.D. Function of trehalose in baker's yeast (Saccharomyces cerevisiae). Archives of Biochemistry and Biophysics, v.98, p. 349-55, 1963.

PANEK, A.D. Energy requirements for trehalose synthesis. Ciência e Cultura, v.23, n.1, p. $75-9,1971$ 
PANEK, A.D. Trehalose synthesis during starvation of baker's yeast. European Journal Applied Microbiology, v.2, n. 1, p.39-46, 1975.

PANEK, A.D. Trehalose metabolism and its role in Saccharomyces cerevisiae. Journal of Biotechnology, v.3, p. 121-30, 1985.

PANEK, A.D. Storage carbohydrates. In: ROSE, A.H.; STEWART HARRISON, J., ed. The yeasts: Academic Press, 1991. v. 4, cap. 13, p. 655-79.

PANEK, A.D.; MANSURE, J.J.C.; ELEUTHERIO, C.A. The role of trehalose in yeast cells under stress. Cryobiology, v.30, p. 238-9, 1993.

PARADA, G.; ACEVEDO, F. On the relation of temperature and RNA content to the specific growth rate in Saccharomyces cerevisiae. Biotechnology and Bioengeneering, v.25, p.2785-8, 1983.

PENNA, M.S.; FERNANDES, J.R.M. Protective role of trehalose in thermal denaturation of yeast pyrophosphatase. Zeitschrift fuer Naturforschung Section C Biosciences, v.49, n.5/6, p. 327-30, 1994. /Resumo em BIOSIS Abstracts on CD-ROM, v.2, 1995/.

RIBEIRO, M.J.S.; SILVA, J.T.; PANEK, A.D. Trehalose metabolism in Saccharomyces cerevisiae during heat-shock. Biochimica et Biophysica Acta, v.1200, n.2, p. 139-47, 1994.

SAJBIDOR, J.; GREGO, J. Fatty acid alterations in Saccharomyces cerevisiae exposed to ethanol stress. FEMS Microbiology Letters, v.93, p. 13-6, 1992. 
SAN-MIGUEL, P.F.; ARGUELLES, J.C. Differential changes in the activity of cytosolic and vacuolar trehalases along the growth cycle of Saccharomyces cerevisiae. Biochimica et Biophysica Acta, v. 1200, n.2, p. 155-60, 1994.

SIDYAKINA, T.M; KISHKOVSKII, Z.N.; KUZNETSOVA, E.V.; SAKHAROVA, T.A. Use of freeze-drying and cryopreservation for long-term storage of wine yeast cultures. Applied Biochemistry and Microbiology, v.22, n.6, p. 694-7, 1987.

SIERKSTRA, L.N.; TER-SCHURE, E.G; VERBAKEL, J.M.A; VERRIPS, C.T. A nitrogen-limited, glucose-repressed, continuous culture of Saccharomyces cerevisiae. Microbiology, v.140, n.3, p. 593-9, 1994. /Resumo em BIOSIS Abstracts on CDROM, v.2, 1995/.

SILVA, F.S.; GOMEZ, J.G.C.; OLIVEIRA, M.S.; ALTERTHUM, F. Freeze-drying of industrial yeast strains: influence of growth conditions, cooling rates and suspending media on the viability of recovered cells. Revista de Microbiologia, v.23, n.2, p. 117-22, $1992 \mathrm{a}$.

SILVA, L.F.; KAMIYA, N.F.; OLIVEIRA, M.S.; ALTERTHUM, F. Comparison of preservation methods applied to yeasts used for ethanol production in Brazil. Revista de Microbiologia, v.23, n.3, p. 177-82, 1992 b.

SINCLAIR, J.L.; ALEXANDER, M. Role of resistance to starvation in bacterial survival in sewage and lake water. Applied and Environmental Microbiology, v.48, p. 410-5, 1984.

SUOMALAINEN, H.; PFAFFLI, S. Changes in the carbohydrate reserves of baker's yeast during growth and on standing. Journal of the Institute of Brewing, v.67, p. 249-54, 1961. 
SUUTARI, M.; LIUKKONEN, K.; LAAKSO, S. Temperature adaptation in yeasts: the role of fatty acids. Journal of General Microbiology, v.136, p. 1469-74, 1990.

SZOPA, J.S.; ZWOLINSKI, G.; KOWAL, K,; KUNICKA, A.; DOBROWOLSKA, I. The effect of substrate feeding on the physiological characteristics and the trehalose content in Saccharomyces cerevisiae. Polish Journal of Food and Nutrition Sciences, v.1, n.2, p. 41-50, 1992. /Resumo em CAB Abstracts on CD-ROM, v.5, 1993-95/.

THEVELEIN, J.M. Regulation of trehalose mobilization in fungi. Microbiological Reviews, v.48, n.1, p. 42-59, 1984.

TRAN-DINH, S.; HERVE, M.; LEBOURGUAIS, O.; JEROME, M.; WIETZERBIN, J. Effects of amphotericin B on the glucose metabolism in Saccharomyces cerevisiae cells. European Journal of Biochemistry, v.197, n. 1, p. 271-9, 1991.

TREVELYAN, W.E. Synthesis and degradation of cellular carbohydrates by yeasts. In: COOK, A.H., ed. The chemistry and biology of yeasts. New York: Academic Press, 1958. cap. 8, p. $369-436$.

TREVELYAN, W.E.; HARRISON, J.S. Studies on yeast metabolism 5. The trehalose content of baker's yeast during anaerobic fermentation. Biochemical Journal, v.62, p. $177-83,1956 \mathrm{a}$.

TREVELYAN, W.E.; HARRISON, J.S. Studies on yeast metabolism 7. Yeast carbohydrate fraction. Separation from nucleic acid, analysis and behaviour during anaerobic fermentation. Biochemical Journal, v.63, p. 23-33, $1956 \mathrm{~b}$. 
TREVELYAN, W.E.; GAMMON, J.N.; WIGGINS, E.H.; HARRISON, J.S. Studies on yeast metabolism. 2. Synthesis of cell carbohydrates during glucose fermentation, and its inhibition by azide. Biochemical Journal, v.50, p. 303-10, 1952.

VALDEZ, G.F. Effect of the rehydratation medium on the recovery of freeze-dried lactic acid bacteria. Applied and Environmental Microbiology, v.50, p. 1339-41, 1985.

WATSON, K.; CAVICCHIOLI, R. Acquisition of ethanol tolerance in yeast cells by heat shock. Biotechnology Letters, v.5, n. 10, p. 683-8, 1983.

WELLMAN, A.M; STEWART, G.G. Storage of brewing yeasts by liquid nitrogen refrigeration. Applied Microbiology, v.26, p. 577-83, 1973.

WIENKEN, A. Trehalose in yeast, stress protection rather than reserve carbohydrate. Antonie van Leeuwenhoek, v.58, p. 209-17, 1990.

WILSON, K.; MCLEOD, B.J. The influence of conditions of growth on the endogenous metabolism of Saccharomyces cerevisiae: effect on protein, carbohydrates, sterol and fatty acid content and on viability. Antonie van Leeuwenhoek, v.42, p. 397-410, 1976.

WINKLER, K; KIENLE, I; BURGERT, M.; WAGNER, J.C.; HOLZER, N. Metabolic regulation of the trehalose content of vegetative yeast. FEBS Letters, v.291, p. 269-72, 1991.

YOSHIKAWA, Y.; MATSUMOTO, K.; NEGATA, K.; SATO, T. Extraction of trehalose from thermally-treated baker's yeast. Bioscience Biotechnology and Biochemistry, v. 58, n. 7, p. $1226-30,1994$. 
APÊNDICE 
Tabela 1: Acúmulo e degradação da trealose endógena pelas leveduras em função do tempo de fermentação.

\begin{tabular}{|c|c|c|c|}
\cline { 2 - 4 } \multicolumn{1}{c|}{} & \multicolumn{3}{c|}{ TREALOSE } \\
\hline LEVED. / TEMPO & TA & IZ-1904 & SA \\
\hline ZERO & 0,90 & 0,60 & 0,90 \\
& 0,90 & 0,56 & 0,93 \\
MINUTOS & 0,86 & 0,60 & 0,90 \\
\hline MEDIAS & 0,89 & 0,59 & 0,91 \\
\hline 60 & 4,34 & 3,78 & 4.41 \\
& 4,34 & 3,74 & 4,56 \\
\hline MINUTOS & 4,45 & 3,78 & 4,45 \\
\hline MEDIAS & 4,38 & 3,77 & 4,47 \\
\hline 120 & 6,21 & 5,16 & 6,28 \\
& 6,32 & 5,27 & 6,32 \\
\hline MINUTOS & 6,28 & 5,12 & 6,32 \\
\hline MEDIAS & 6,27 & 5,18 & 6,31 \\
\hline MI80 & 5,05 & 3,93 & 5,12 \\
& 5,12 & 4,00 & 5,09 \\
\hline MINUTOS & 5,09 & 4,00 & 5,31 \\
\hline MEDIAS & 5,09 & 3.98 & 5,17 \\
\hline 240 & 4,83 & 3,10 & 4,90 \\
\hline MINUTIOSIAS & 4,42 & 2,57 & 4,50 \\
\hline
\end{tabular}


Tabela 2: Efeito dos tratamentos no teor da trealose endógena da levedura TA, na sua viabilidade inicial e aos 10,40 e 90 dias após liofilização.

\begin{tabular}{|c|c|c|c|c|c|}
\hline $\begin{array}{l}\text { ANALISES / } \\
\text { TRATAMENTO }\end{array}$ & $\begin{array}{c}\text { TREALOSE } \\
\%\end{array}$ & $\begin{array}{l}\text { VIABILID. } \\
\text { INICIAL \% }\end{array}$ & $\begin{array}{l}\text { VIABILID. } \\
10 \text { DIAS \% }\end{array}$ & $\begin{array}{l}\text { VIABILID. } \\
40 \text { DIAS \% }\end{array}$ & $\begin{array}{l}\text { VIABILID. } \\
90 \text { DIAS \% }\end{array}$ \\
\hline \multirow{3}{*}{$\mathrm{T} 1$} & 0,86 & 99.08 & 30,68 & 26,32 & 26,17 \\
\hline & 0,82 & 99,27 & 27,75 & 27,58 & 27,70 \\
\hline & 0,86 & 99,05 & 33,89 & 33,06 & 30,89 \\
\hline MÉDIAS & 0.85 & 99,13 & 30,50 & 28,99 & 28.25 \\
\hline \multirow{3}{*}{$\mathrm{T} 2$} & 0,86 & 98,99 & 18,18 & 16,70 & 16,20 \\
\hline & 0,89 & 99.09 & 20.82 & 19.19 & 17,99 \\
\hline & 0,78 & 98.93 & 23,68 & 21.12 & 20,89 \\
\hline MÉDIAS & 0.84 & 99,00 & 20,89 & 19,00 & 18,36 \\
\hline \multirow{3}{*}{$\mathrm{T} 3$} & 0,86 & 99,01 & 27,13 & 24,81 & 23,40 \\
\hline & 0,86 & 98,54 & 23,20 & 24,34 & 23,11 \\
\hline & 0,82 & 99,05 & 30,23 & 27.79 & 25,50 \\
\hline MEDIAS & 0,85 & 98,87 & 26,85 & 25,65 & 24,00 \\
\hline \multirow{3}{*}{$\mathrm{T} 4$} & 6,41 & 93,45 & 57,26 & 55,17 & 53,20 \\
\hline & 6,44 & 93,57 & 50,41 & 49,00 & 48,27 \\
\hline & 6,33 & 92.88 & 57.22 & 53,80 & 51,93 \\
\hline MEDIAS & 6.39 & 93.30 & 54,96 & 52,66 & 51.13 \\
\hline \multirow{3}{*}{ T5 } & 6,37 & 93.54 & 31,64 & 29.98 & 29,10 \\
\hline & 6,41 & 93,72 & 36,91 & 34,78 & 32,91 \\
\hline & 6,30 & 93,36 & 32,83 & 28,81 & 29,78 \\
\hline MÉDIAS & 6,36 & 93,54 & 33,79 & 31,19 & 30,60 \\
\hline \multirow{3}{*}{ T6 } & 6,33 & 93,75 & 39.31 & 36,30 & 35.88 \\
\hline & 6.22 & 93,45 & 37,82 & 35,41 & 35,88 \\
\hline & 6,18 & 93,48 & 45.12 & 42.50 & 42,42 \\
\hline MEDIAS & 6.24 & 93,56 & 40,75 & 38.07 & 38,06 \\
\hline
\end{tabular}


Tabela 3: Efeito dos tratamentos na manutenção da viabilidade pela levedura TA aos 10 , 40 e 90 dias após liofilização.

\begin{tabular}{|c|c|c|c|}
\hline $\begin{array}{c}\text { ANÁLISES / } \\
\text { TRATAMENTO }\end{array}$ & $\begin{array}{l}\text { MANUTENÇÃO } \\
\text { VIABIL. } 10 \text { DIAS \% }\end{array}$ & $\begin{array}{c}\text { MANUTENÇÃO } \\
\text { VIABIL. } 40 \text { DIAS \% }\end{array}$ & $\begin{array}{c}\text { MANUTENÇÃO } \\
\text { VIABIL. } 90 \text { DIAS \% }\end{array}$ \\
\hline $\mathrm{TI}$ & $\begin{array}{l}30,96 \\
27,95 \\
34,22\end{array}$ & $\begin{array}{l}26,56 \\
27,78 \\
33,38\end{array}$ & $\begin{array}{l}26,41 \\
27,90 \\
31,19\end{array}$ \\
\hline MEDIAS & 31,04 & 29,24 & 28,50 \\
\hline $\mathrm{T} 2$ & $\begin{array}{l}18,37 \\
21,01 \\
23,94\end{array}$ & $\begin{array}{l}16,87 \\
19,37 \\
21,35\end{array}$ & $\begin{array}{l}16,37 \\
18,16 \\
21,12\end{array}$ \\
\hline MÉDIAS & 21,11 & 19,20 & 18,55 \\
\hline $\mathrm{T} 3$ & $\begin{array}{l}27,40 \\
23,54 \\
30,52\end{array}$ & $\begin{array}{l}25,06 \\
24,70 \\
28,06\end{array}$ & $\begin{array}{l}23,63 \\
23,45 \\
25,74\end{array}$ \\
\hline MEDDIAS & 27,15 & 25,94 & 24,27 \\
\hline $\mathrm{T} 4$ & $\begin{array}{l}61,27 \\
53,87 \\
61,61\end{array}$ & $\begin{array}{l}59,04 \\
52,37 \\
57,92\end{array}$ & $\begin{array}{l}56,93 \\
51,59 \\
55,91\end{array}$ \\
\hline MEDIAS & 58,92 & 56.44 & 54,81 \\
\hline T5 & $\begin{array}{l}33,83 \\
39,38 \\
35,16\end{array}$ & $\begin{array}{l}32,05 \\
37,11 \\
30,86\end{array}$ & $\begin{array}{l}31,11 \\
35,12 \\
31,90\end{array}$ \\
\hline MÉDIAS & 36,12 & 33,34 & 32,71 \\
\hline T6 & $\begin{array}{l}41,93 \\
40,47 \\
48,27\end{array}$ & $\begin{array}{l}38,72 \\
37,89 \\
45,46\end{array}$ & $\begin{array}{l}38,27 \\
38,39 \\
45,38\end{array}$ \\
\hline MEDIAS & 43,56 & 40,69 & 40,68 \\
\hline
\end{tabular}


Tabela 4: Efeito dos tratamentos no teor da trealose endógena da levedura IZ-1904, na sua viabilidade inicial e aos 10, 40 e 90 dias após liofilização.

\begin{tabular}{|c|c|c|c|c|c|}
\hline $\begin{array}{c}\text { ANÁLISES / } \\
\text { TRATAMENTO }\end{array}$ & $\begin{array}{c}\text { TREALOSE } \\
\%\end{array}$ & $\begin{array}{l}\text { VIABILID. } \\
\text { INICIAL \% }\end{array}$ & $\begin{array}{l}\text { VIABILID. } \\
10 \text { DIAS \% }\end{array}$ & $\begin{array}{l}\text { VIABILID. } \\
\text { to DIAS } \%\end{array}$ & $\begin{array}{l}\text { VIABILID. } \\
90 \text { DIAS \% }\end{array}$ \\
\hline \multirow{3}{*}{$\mathrm{T} 1$} & 0,63 & 96,01 & 29,51 & 28,31 & 27,39 \\
\hline & 0,67 & 95,08 & 27,45 & 26,30 & 25,21 \\
\hline & 0,63 & 96,06 & 24,40 & 23,12 & 22.81 \\
\hline MÉDIAS & 0,64 & 95.71 & 27,12 & 25.91 & 25,14 \\
\hline \multirow{3}{*}{$\mathrm{T} 2$} & 0,60 & 95,74 & 20,20 & 18,81 & 18,41 \\
\hline & 0.63 & 96.22 & 19,21 & 17.90 & 16.49 \\
\hline & 0,67 & 96,13 & 14,61 & 15,00 & 14,92 \\
\hline MEDIAS & 0,63 & 96,03 & 18.01 & 17,24 & 16,61 \\
\hline \multirow{3}{*}{$\mathrm{T} 3$} & 0,67 & 95,93 & 20,29 & 19,49 & 19,13 \\
\hline & 0,67 & 95,81 & 22.70 & 21,88 & 20,59 \\
\hline & 0,60 & 97,00 & 26,08 & 22.82 & 23,32 \\
\hline MÉDIAS & 0,65 & 96.24 & 23,02 & 21,40 & 21,01 \\
\hline \multirow{3}{*}{$\mathrm{T} 4$} & 5,10 & 89,91 & 46,70 & 44,22 & 43,78 \\
\hline & 5,18 & 90,00 & 43,90 & 44.24 & 42,41 \\
\hline & 5,18 & 90,28 & 53,65 & 50,21 & 49,90 \\
\hline MEDIAS & 5,15 & 90.36 & 48,08 & 46.22 & 45,36 \\
\hline \multirow{3}{*}{$\mathrm{T} 5$} & 5,25 & 89.74 & 33,30 & 30.21 & 28,78 \\
\hline & 5.25 & 90.54 & 30,72 & 27,79 & 27,43 \\
\hline & 5,14 & 90,14 & 26,31 & 27,71 & 26,88 \\
\hline MEDIAS & 5,21 & 90,14 & 30,11 & 28,57 & 27,70 \\
\hline \multirow{3}{*}{ T6 } & 5,03 & 90,85 & 34,82 & 31,80 & 31,20 \\
\hline & 5,14 & 90,26 & 40.23 & 36.20 & 35,78 \\
\hline & 5,07 & 89,97 & 38.83 & 37.52 & 36.43 \\
\hline MEDIAS & 5,08 & 90,07 & 37.96 & 35.17 & 34,47 \\
\hline
\end{tabular}


Tabela 5: Efeito dos tratamentos na manutenção da viabilidade pela levedura IZ-1904 aos 10,40 e 90 dias após liofilização.

\begin{tabular}{|c|c|c|c|}
\hline $\begin{array}{c}\text { ANÁLISES / } \\
\text { TRATAMENTO }\end{array}$ & $\begin{array}{l}\text { MANUTENÇÃO } \\
\text { VIABIL. } 10 \text { DIAS \% }\end{array}$ & $\begin{array}{c}\text { MANUTENÇÃO } \\
\text { VIABIL. } 40 \text { DIAS \% }\end{array}$ & $\begin{array}{c}\text { MANUTENÇÃO } \\
\text { VIABIL. } 90 \text { DIAS \% }\end{array}$ \\
\hline $\mathrm{T} 1$ & $\begin{array}{l}30,74 \\
28,87 \\
25,26\end{array}$ & $\begin{array}{l}29,49 \\
27,66 \\
24,07\end{array}$ & $\begin{array}{l}28,53 \\
26,51 \\
23,75\end{array}$ \\
\hline MEDIAS & 28.29 & 27,07 & 26,26 \\
\hline $\mathrm{T} 2$ & $\begin{array}{l}21,10 \\
19.96 \\
15,20\end{array}$ & $\begin{array}{l}19,65 \\
18,60 \\
15,60\end{array}$ & $\begin{array}{l}19.23 \\
17.14 \\
15,52\end{array}$ \\
\hline MEDIAS & 18,75 & 17,95 & 17,30 \\
\hline T3 & $\begin{array}{l}21,15 \\
23,69 \\
26,89\end{array}$ & $\begin{array}{l}20,32 \\
22,84 \\
23,53\end{array}$ & $\begin{array}{l}19,94 \\
21,49 \\
24,04\end{array}$ \\
\hline MEDIAS & 23,91 & 22,23 & 21,82 \\
\hline $\mathrm{T} 4$ & $\begin{array}{l}51,94 \\
48.78 \\
59,43\end{array}$ & $\begin{array}{l}49,18 \\
49,16 \\
55,62\end{array}$ & $\begin{array}{r}48.69 \\
+7,12 \\
55,27\end{array}$ \\
\hline MEDIAS & 53,38 & 51,32 & 50.36 \\
\hline T5 & $\begin{array}{l}37,11 \\
33,93 \\
29,19\end{array}$ & $\begin{array}{l}33,66 \\
30,69 \\
30,74\end{array}$ & $\begin{array}{l}32,07 \\
30,30 \\
29,82\end{array}$ \\
\hline MEDIAS & 33,41 & 31,70 & 30,73 \\
\hline T6 & $\begin{array}{l}38,33 \\
44,57 \\
43,16\end{array}$ & $\begin{array}{l}35,00 \\
40,11 \\
41,70\end{array}$ & $\begin{array}{r}34.34 \\
39.64 \\
40.49\end{array}$ \\
\hline MEDIAS & 42,02 & 38,94 & 38.16 \\
\hline
\end{tabular}


Tabela 6: Efeito dos tratamentos no teor da trealose endógena da levedura SA, na sua viabilidade inicial e aos 10, 40 e 90 dias após liofilização.

\begin{tabular}{|c|c|c|c|c|c|}
\hline $\begin{array}{l}\text { ANÁLISES / } \\
\text { TRATAMENTO }\end{array}$ & $\begin{array}{c}\text { TREALOSE } \\
\%\end{array}$ & $\begin{array}{l}\text { VIABILID. } \\
\text { INICIAL \% }\end{array}$ & $\begin{array}{l}\text { VIABILID. } \\
10 \text { DIAS \% }\end{array}$ & $\begin{array}{l}\text { VIABILID. } \\
40 \text { DIAS } \%\end{array}$ & $\begin{array}{l}\text { VIABILID. } \\
90 \text { DIAS \% }\end{array}$ \\
\hline \multirow{3}{*}{$\mathrm{T} 1$} & 0.84 & 99,48 & 31.71 & 29.88 & 30,63 \\
\hline & 0,80 & 99,59 & 28,79 & 27,80 & 27.56 \\
\hline & 0.84 & 98,90 & 37,20 & 34,92 & 33,71 \\
\hline MEDIAS & 0.83 & 99,32 & 32,57 & 30,87 & 30,63 \\
\hline \multirow{3}{*}{$\mathrm{T} 2$} & 0,73 & 99,01 & 20.50 & 19.19 & 18,29 \\
\hline & 0.84 & 99,17 & 23,32 & 21.51 & 20,90 \\
\hline & 0,84 & 99,30 & 21,20 & 20,09 & 20,61 \\
\hline MEDIAS & 0,80 & 99,16 & 21,67 & 20,26 & 19,93 \\
\hline \multirow{3}{*}{ T3 } & 0.84 & 98,91 & 28,72 & 27,72 & 26,81 \\
\hline & 0.80 & 98,65 & 24,70 & 22.71 & 22,12 \\
\hline & 0,80 & 99,50 & 30,53 & 28,32 & 26,59 \\
\hline MEDIAS & 0.81 & 99,02 & 27,98 & 26,25 & 25,17 \\
\hline \multirow{3}{*}{$\mathrm{T} 4$} & 6,02 & 95,58 & 60,75 & 56,80 & 54,25 \\
\hline & 6.05 & 94,02 & 53,23 & 51,87 & 51,24 \\
\hline & 6.28 & 92,07 & 54,04 & 51,78 & 52.11 \\
\hline MEDIAS & 6.12 & 93.89 & 56.01 & 53,48 & 52.53 \\
\hline \multirow{3}{*}{ T5 } & 6.46 & 92,94 & 36.42 & 33,69 & 32.42 \\
\hline & 6.20 & 94,44 & 36,92 & 35,11 & 34,90 \\
\hline & 6,35 & 93,05 & 31.72 & 30.38 & 29.60 \\
\hline MEDIAS & 6.34 & 93,48 & 35,02 & 33,06 & 32,31 \\
\hline \multirow{3}{*}{ T6 } & 6.31 & 94.68 & 39,68 & 37.59 & 37,01 \\
\hline & 6.31 & 93,01 & 42,70 & 38.87 & 38.40 \\
\hline & 6.13 & 92,95 & 43,07 & 43,57 & 41.32 \\
\hline MEDIAS & 6.25 & 93,55 & 41,82 & 40.01 & 38,91 \\
\hline
\end{tabular}


Tabela 7: Efeito dos tratamentos na manutenção da viabilidade pela levedura SA aos 10 , 40 e 90 dias após liofilização.

\begin{tabular}{|c|c|c|c|}
\hline $\begin{array}{c}\text { ANÁLISES / } \\
\text { TRATAMENTO }\end{array}$ & $\begin{array}{l}\text { MANUTENÇAOO } \\
\text { VIABIL, } 10 \text { DIAS \% }\end{array}$ & $\begin{array}{c}\text { MANUTENÇÃO } \\
\text { VIABIL. } 40 \text { DIAS \% }\end{array}$ & $\begin{array}{c}\text { MANUTENÇÃO } \\
\text { VIABIL. } 90 \text { DIAS \% }\end{array}$ \\
\hline $\mathrm{T} 1$ & $\begin{array}{l}31,88 \\
28,91 \\
37,61\end{array}$ & $\begin{array}{l}30,04 \\
27,91 \\
35,31\end{array}$ & $\begin{array}{l}30,79 \\
27,67 \\
34,08\end{array}$ \\
\hline MEDIAS & 32,80 & 31,09 & 30,85 \\
\hline $\mathrm{T} 2$ & $\begin{array}{l}20,70 \\
23,52 \\
21,35\end{array}$ & $\begin{array}{l}19,38 \\
21,69 \\
20,23\end{array}$ & $\begin{array}{l}18,47 \\
21.07 \\
20,76\end{array}$ \\
\hline MEDIAS & 21,86 & 20,43 & 20,10 \\
\hline T3 & $\begin{array}{l}29,04 \\
25,04 \\
30,68\end{array}$ & $\begin{array}{l}28,03 \\
23,02 \\
28,46\end{array}$ & $\begin{array}{l}27,11 \\
22,42 \\
26,72\end{array}$ \\
\hline MEDIAS & 28,25 & 26,50 & 25,42 \\
\hline $\mathrm{T} 4$ & $\begin{array}{l}63,56 \\
56,62 \\
58,69\end{array}$ & $\begin{array}{l}59,43 \\
55,17 \\
56,24\end{array}$ & $\begin{array}{l}56,76 \\
54,50 \\
56,60\end{array}$ \\
\hline MEDIAS & 59.62 & 56.95 & 55,95 \\
\hline T5 & $\begin{array}{l}39,19 \\
39,09 \\
34,09\end{array}$ & $\begin{array}{l}36,25 \\
37,18 \\
32,65\end{array}$ & $\begin{array}{l}34,88 \\
36,95 \\
31,81\end{array}$ \\
\hline MEDIAS & 37,46 & 35,36 & 34,55 \\
\hline T6 & $\begin{array}{r}41,91 \\
+5,91 \\
46,34\end{array}$ & $\begin{array}{l}39,70 \\
41,79 \\
46,87\end{array}$ & $\begin{array}{r}39,09 \\
41,29 \\
44,45\end{array}$ \\
\hline MEDIAS & 44,72 & 42,79 & 41,61 \\
\hline
\end{tabular}


Tabela 8: Análise da variância para o efeito acúmulo da trealose endógena pela levedura TA.

\begin{tabular}{|c|r|c|c|c|c|}
\hline \multicolumn{7}{|c|}{ Analise da Variancia - Contrastes Ortogonais } \\
\hline Source & DF & Sum of Squares & Mean Square & F Value & Pr $>$ F \\
\hline Model & 5 & 135,5030444 & 27,1006089 & 9756,22 & $0,0001^{* *}$ \\
\hline Error & 12 & 0,0333333 & 0,0027778 & & \\
\hline Corrected Total & 17 & 135,5363778 & & & \\
\hline \multicolumn{7}{|c|}{ CONTRAST Statement Results } \\
\hline Contrast & DF & Contrast SS & Mean Square & F Value & Pr $>$ F \\
\hline ACUM x ESGOT & 1 & 135,4658000 & 135,4658000 & 48767,69 & $0,0001^{* *}$ \\
\hline
\end{tabular}

Tabela 9: Análise da variância para o efeito manutenção da viabilidade celular pela levedura TA aos 10 dias após liofilização.

\begin{tabular}{|c|c|c|c|c|c|}
\hline \multicolumn{6}{|c|}{$\begin{array}{l}\text { Analise da Variancia - Contrastes Ortogonais } \\
\text { General Linear Models Procedure }\end{array}$} \\
\hline Source & DF & Sum of Squares & Mean Square & F Value & $\operatorname{Pr}>F$ \\
\hline Model & 5 & 2719,001400 & 543,800280 & $+3,77$ & $0,0001^{* *}$ \\
\hline Error & 12 & 149,088200 & 12,424017 & & \\
\hline Corrected Total & 17 & 2868,089600 & & & \\
\hline \multicolumn{6}{|c|}{ CONTRAST Statement Results } \\
\hline Contrast & $\overline{\mathrm{DF}}$ & Contrast SS & Mean Square & F Value & Pr $>F$ \\
\hline $\mathrm{T} 1,2,3 \times \mathrm{T} 4,5,6$ & 1 & 1757,849689 & 1757.849689 & 141,49 & $0,0001 * *$ \\
\hline $\mathrm{T} 1 \times \mathrm{T} 2$ & 1 & 148,106017 & 148.106017 & 11,92 & $0,0048^{* *}$ \\
\hline $\mathrm{T} 1 \times \mathrm{T} 3$ & 1 & 22,698150 & 22,698150 & 1,83 & $0,2014 \mathrm{~ns}$ \\
\hline $\mathrm{T} 2 \times \mathrm{T} 3$ & 1 & 54,843267 & 54,843267 & 4,41 & $0,0574 \mathrm{~ns}$ \\
\hline $\mathrm{T} 4 \times \mathrm{T} 5$ & 1 & 779,304067 & 779,304067 & 62,73 & $0,0001^{* *}$ \\
\hline T4xT6 & 1 & 353,894400 & 353,894400 & 28,48 & $0,0002 * *$ \\
\hline $\mathrm{T} 5 \times \mathrm{T} 6$ & 1 & 82,881667 & 82.881667 & 6,67 & $0,0240^{*}$ \\
\hline
\end{tabular}


Tabela 10: Análise da variância para o efeito manutenção da viabilidade celular pela levedura TA aos 10, 40 e 90 dias após liofilização.

\begin{tabular}{|c|c|c|c|c|c|}
\hline \multicolumn{6}{|c|}{ Analise da Variancia - Contrastes Ortogonais - Tratamento Tl } \\
\hline \multicolumn{6}{|c|}{ General Linear Models Procedure } \\
\hline Source & DF & Sum of Squares & Mean Square & F Value & $\operatorname{Pr}>F$ \\
\hline Model & 2 & 10,26815556 & 5,13407778 & 0.53 & $0,6136 \mathrm{~ns}$ \\
\hline Error & 6 & 58,08466667 & 9,68077778 & & \\
\hline Corrected Total & 8 & 68,35282222 & & & \\
\hline \multicolumn{6}{|c|}{ Analise da Variancia - Contrastes Ortogonais - Tratamento T2 } \\
\hline \multicolumn{6}{|c|}{ General Linear Models Procedure } \\
\hline Source & $\mathrm{DF}$ & Sum of Squares & Mean Square & F Value & $\operatorname{Pr}>\mathrm{F}$ \\
\hline Model & 2 & 10,60282222 & 5,30141111 & 0,86 & $0,4706 \mathrm{~ns}$ \\
\hline Error & 6 & 37,11613333 & 6,18602222 & & \\
\hline Corrected Total & 8 & 47,71895556 & & & \\
\hline \multicolumn{6}{|c|}{ Analise da Variancia - Contrastes Ortogonais - Tratamento T3 } \\
\hline \multicolumn{6}{|c|}{ General Linear Models Procedure } \\
\hline Source & DF & Sum of Squares & Mean Square & F Value & $\operatorname{Pr}>\mathrm{F}$ \\
\hline Model & 2 & 12,54435556 & 6,27217778 & 1,09 & $0,3944 \mathrm{~ns}$ \\
\hline Error & 6 & 34,50073333 & 5.75012222 & & \\
\hline Corrected Total & 8 & 47,04508889 & & & \\
\hline \multicolumn{6}{|c|}{ Analise da Variancia - Contrastes Ortogonais - Tratamento $\mathrm{Tt}$} \\
\hline \multicolumn{6}{|c|}{ General Linear Models Procedure } \\
\hline Source & DF & Sum of Squares & Mean Square & F Value & $\operatorname{Pr}>F$ \\
\hline Model & 2 & 25,64986667 & 12.82493333 & 0.96 & $0,4336 \mathrm{~ns}$ \\
\hline Error & $\overline{6}$ & 79,84913333 & 13,30818889 & & \\
\hline Corrected Total & 8 & 105,49900000 & & & \\
\hline \multicolumn{6}{|c|}{ Analise da Variancia - Contrastes Ortogonais - Tratamento T5 } \\
\hline \multicolumn{6}{|c|}{ General Linear Models Procedure } \\
\hline Source & $\mathrm{DF}$ & Sum of Squares & Mean Square & F Value & $\operatorname{Pr}>F$ \\
\hline Model & 2 & 19,68722222 & 9.84361111 & 1,23 & $0,3569 \mathrm{~ns}$ \\
\hline Error & 6 & 48.03873333 & 8,00645556 & & \\
\hline Corrected Total & 8 & 67.72595556 & & & \\
\hline
\end{tabular}


Analise da Variancia - Contrastes Ortogonais - Tratamento T6 General Linear Models Procedure

\begin{tabular}{|c|c|c|c|c|c|}
\hline Source & DF & Sum of Squares & Mean Square & F Value & Pr $>$ F \\
\hline Model & 2 & 16,49308889 & 8.24654444 & 0.49 & $0.6379 \mathrm{~ns}$ \\
\hline Error & 6 & 102,00506667 & 17,00084444 & & \\
\hline Corrected Total & 8 & 118,49815556 & & & \\
\hline
\end{tabular}

Tabela 11: Análise da variància para o efeito acúmulo da trealose endógena pela levedura IZ-1904.

Analise da Variancia - Contrastes Ortogonais

General Linear Models Procedure

\begin{tabular}{|c|c|c|c|c|c|}
\hline Source & DF & Sum of Squares & Mean Square & F Value & Pr $>$ F \\
\hline Model & 5 & 91,46731667 & 18,29346333 & 8665,32 & $0,0001^{* *}$ \\
\hline Error & 12 & 0,02533333 & 0,00211111 & & \\
\hline Corrected Total & 17 & 91,49265000 & & & \\
\hline \multicolumn{7}{|c|}{ CONTRAST Statement Results } \\
\hline Contrast & DF & Contrast SS & Mean Square & F Value & Pr $>$ F \\
\hline ACUM $\times$ ESGOT & 1 & 91,44027222 & 91,44027222 & 43313,81 & $0.0001^{* *}$ \\
\hline
\end{tabular}


Tabela 12: Análise da variância para o efeito manutenção da viabilidade celular pela levedura IZ-1904 aos 10 dias após liofilização.

\begin{tabular}{|c|c|c|c|c|c|}
\hline \multicolumn{6}{|c|}{$\begin{array}{c}\text { Analise da Variancia - Contrastes Ortogonais } \\
\text { General Linear Models Procedure }\end{array}$} \\
\hline Source & $\overline{\mathrm{DF}}$ & Sum of Squares & Mean Square & F Value & $\operatorname{Pr}>F$ \\
\hline Model & 5 & 2411,596983 & 482,319397 & 35,34 & $0.0001^{* *}$ \\
\hline Error & 12 & 163,783467 & 13,648622 & & \\
\hline Corrected Total & 17 & 2575,380450 & & & \\
\hline \multicolumn{6}{|c|}{ CONTRAST Statement Results } \\
\hline Contrast & $\overline{D F}$ & Contrast SS & Mean Square & F Value & $\operatorname{Pr}>F$ \\
\hline $\mathrm{T} 1,2,3 \times \mathrm{T} 4,5,6$ & 1 & 1671,383472 & 1671,383472 & 122,46 & $0.0001^{* *}$ \\
\hline $\mathrm{T} 1 \times \mathrm{T} 2$ & 1 & 137,760417 & 137,760417 & 10,09 & $0,0080^{* *}$ \\
\hline $\mathrm{T} 1 \times \mathrm{T} 3$ & 1 & 29,437350 & 29,437350 & 2,16 & $0.1677 \mathrm{~ns}$ \\
\hline $\mathrm{T} 2 \times \mathrm{T} 3$ & 1 & 39,835267 & 39,835267 & 2,92 & $0,1133 \mathrm{~ns}$ \\
\hline T4 $\mathrm{T}$ T5 & I & 598,401067 & 598,401067 & 43,84 & $0,000 \mathrm{I}^{* *}$ \\
\hline $\mathrm{T} 4 \times \mathrm{T} 6$ & 1 & 193,688017 & 193,688017 & 14,19 & $0,0027^{* *}$ \\
\hline $\mathrm{T} 5 \times \mathrm{T} 6$ & 1 & 111,198150 & 111,198150 & 8,15 & $0,0145^{*}$ \\
\hline
\end{tabular}

Tabela 13: Análise da variância para o efeito manutenção da viabilidade celular pela levedura IZ-1904 aos 10, 40 e 90 dias após liofilização.

\begin{tabular}{|c|c|c|c|c|c|}
\hline \multicolumn{7}{|c|}{$\begin{array}{l}\text { Analise da Variancia - Contrastes Ortogonais - Tratamento T1 } \\
\text { General Linear Models Procedure }\end{array}$} \\
\hline Source & DF & Sum of Squares & Mean Square & F Value & Pr > F \\
\hline Model & 2 & 6.55082222 & 3.27541111 & 0.47 & $0.6436 \mathrm{~ns}$ \\
\hline Error & 6 & 41,40440000 & 6,90073333 & & \\
\hline Corrected Total & 8 & $+7,95522222$ & & & \\
\hline
\end{tabular}


Analise da Variancia - Contrastes Ortogonais - Tratamento T2

General Linear Models Procedure

\begin{tabular}{|c|c|c|c|c|c|}
\hline Source & DF & Sum of Squares & Mean Square & F Value & $\operatorname{Pr}>F$ \\
\hline Model & 2 & 3,19406667 & 1.59703333 & 0.27 & 0,7714 ns \\
\hline Error & 6 & 35,34293333 & $5.890+8889$ & & \\
\hline Corrected Total & 8 & 38,53700000 & & & \\
\hline \multicolumn{6}{|c|}{ Analise da Variancia - Contrastes Ortogonais - Tratamento T3 } \\
\hline \multicolumn{6}{|c|}{ General Linear Models Procedure } \\
\hline Source & $\mathrm{DF}$ & Sum of Squares & Mean Square & F Value & $\operatorname{Pr}>F$ \\
\hline Model & 2 & 7.31686667 & 3.65843333 & 0,71 & $0,5273 \mathrm{~ns}$ \\
\hline Error & 6 & 30,76873333 & 5.12812222 & & \\
\hline Corrected Total & 8 & 38,08560000 & & & \\
\hline \multicolumn{6}{|c|}{ Analise da Variancia - Contrastes Ortogonais - Tratamento T4 } \\
\hline \multicolumn{6}{|c|}{ General Linear Models Procedure } \\
\hline Source & DF & Sum of Squares & Mean Square & F Value & $\operatorname{Pr}>F$ \\
\hline Model & 2 & 14,31948889 & 7,15974444 & 0,34 & $0,7222 \mathrm{~ns}$ \\
\hline Error & $\overline{6}$ & 124,96586667 & 20,82764444 & & \\
\hline Corrected Total & 8 & 139,28535556 & & & \\
\hline \multicolumn{6}{|c|}{ Analise da Variancia - Contrastes Ortogonais - Tratamento T5 } \\
\hline \multicolumn{6}{|c|}{ General Linear Models Procedure } \\
\hline Source & $\overline{\mathrm{DF}}$ & Sum of Squares & Mean Square & F Value & $\operatorname{Pr}>F$ \\
\hline Model & 2 & 11,05235556 & 5,52617778 & 0,82 & $0.4838 \mathrm{~ns}$ \\
\hline Error & 6 & 40,36066667 & 6,72677778 & & \\
\hline Corrected Total & 8 & 51,41302222 & & & \\
\hline \multicolumn{6}{|c|}{ Analise da Variancia - Contrastes Ortogonais - Tratamento T6 } \\
\hline \multicolumn{6}{|c|}{ General Linear Models Procedure } \\
\hline Source & DF & Sum of Squares & Mean Square & F Value & $\operatorname{Pr}>F$ \\
\hline Model & 2 & 25,04068889 & 12.52034444 & 1.10 & $0,3910 \mathrm{~ns}$ \\
\hline Error & 6 & 68,13993333 & 11,35665556 & & \\
\hline Corrected Total & 8 & 93,18062222 & & & \\
\hline
\end{tabular}


Tabela 14: Análise da variância para o efeito acúmulo da trealose endógena pela levedura SA.

\begin{tabular}{|c|c|c|c|c|c|}
\hline \multicolumn{7}{|c|}{$\begin{array}{c}\text { Analise da Variancia - Contrastes Ortogonais } \\
\text { General Linear Models Procedure }\end{array}$} \\
\hline Source & DF & Sum of Squares & Mean Square & F Value & Pr $>\mathrm{F}$ \\
\hline Model & 5 & 132,7895333 & 26,5579067 & 2187,84 & $0,0001^{* *}$ \\
\hline Error & 12 & 0,1456667 & 0,0121389 & & \\
\hline Corrected Total & 17 & 132,9352000 & & & \\
\hline \multicolumn{7}{|c|}{ CONTRAST Statement Results } & & Pr $>$ F \\
\hline Contrast & DF & Contrast SS & Mean Square & F Value & $0,0001^{* *}$ \\
\hline ACUM x ESGOT & 1 & 132,7363556 & 132,7363556 & 10934.80 & 0,0036 \\
\hline
\end{tabular}

Tabela 15: Análise da variância para o efeito manutenção da viabilidade celular pela levedura SA aos 10 dias após liofilização.

\begin{tabular}{|c|c|c|c|c|c|}
\hline \multicolumn{6}{|c|}{$\begin{array}{l}\text { Analise da Variancia - Contrastes Ortogonais } \\
\text { General Linear Models Procedure }\end{array}$} \\
\hline Source & DF & Sum of Squares & Mean Square & F Value & $\operatorname{Pr}>F$ \\
\hline Model & 5 & 2681.588583 & 536,317717 & 56,14 & $0,0001^{* *}$ \\
\hline Error & 12 & 114,640667 & 9,553389 & & \\
\hline Corrected Total & 17 & 2796,229250 & & & \\
\hline \multicolumn{6}{|c|}{ CONTRAST Statement Results } \\
\hline Contrast & DF & Contrast SS & Mean Square & F Value & $\operatorname{Pr}>F$ \\
\hline $\mathrm{T} 1.2 .3 \times \mathrm{T} 4.5 .6$ & 1 & 1734,016050 & 1734,016050 & 181,51 & $0,0001^{* *}$ \\
\hline $\mathrm{T} 1 \times \mathrm{T} 2$ & 1 & 179,634817 & 179.634817 & 18.80 & $0,0010^{* *}$ \\
\hline $\mathrm{T} 1 \times \mathrm{T} 3$ & 1 & 31,008267 & 31,008267 & 3,25 & $0,0968 \mathrm{~ns}$ \\
\hline $\mathrm{T} 2 \times \mathrm{T} 3$ & 1 & 61,376017 & 61,376017 & 6,42 & $0,0262^{*}$ \\
\hline$T+x T 5$ & 1 & 737.041667 & 737,041667 & 77.15 & $0,0001^{* *}$ \\
\hline $\mathrm{T}+\mathrm{xT6}$ & 1 & 333,164017 & 333,164017 & 34,87 & $0,0001^{* *}$ \\
\hline T5 $\times 16$ & 1 & 79,134017 & 79,134017 & 8,28 & $0,0139^{*}$ \\
\hline
\end{tabular}


Tabela 16: Análise da variância para o efeito manutenção da viabilidade celular pela levedura SA aos 10, 40 e 90 dias após liofilização.

\begin{tabular}{|c|c|c|c|c|c|}
\hline \multicolumn{6}{|c|}{ Analise da Variancia - Contrastes Ortogonais - Tratamento TI } \\
\hline \multicolumn{6}{|c|}{ General Linear Models Procedure } \\
\hline Source & DF & Sum of Squares & Mean Square & F Value & $\operatorname{Pr}>F$ \\
\hline Model & 2 & 6,80862222 & 3,40431111 & 0.23 & $0,8010 \mathrm{~ns}$ \\
\hline Error & 6 & 88,68673333 & 14,78112222 & & \\
\hline Corrected Total & 8 & 95,49535556 & & & \\
\hline \multicolumn{6}{|c|}{ Analise da Variancia - Contrastes Ortogonais - Tratamento T2 } \\
\hline \multicolumn{6}{|c|}{ General Linear Models Procedure } \\
\hline Source & $\overline{\mathrm{DF}}$ & Sum of Squares & Mean Square & F Value & $\operatorname{Pr}>F$ \\
\hline Model & 2 & 5.22286667 & 2,61143333 & 1,41 & $0,315 \operatorname{lns}$ \\
\hline Error & 6 & 11,12473333 & 1,85412222 & & \\
\hline Corrected Total & 8 & 16,34760000 & & & \\
\hline \multicolumn{6}{|c|}{ Analise da Variancia - Contrastes Ortogonais - Tratamento T3 } \\
\hline \multicolumn{6}{|c|}{ General Linear Models Procedure } \\
\hline Source & DF & Sum of Squares & Mean Square & F Value & $\operatorname{Pr}>F$ \\
\hline Model & 2 & 12,29002222 & 6,14501111 & 0,76 & $0,5089 \mathrm{~ns}$ \\
\hline Error & $\overline{6}$ & 48,67200000 & 8,11200000 & & \\
\hline Corrected Total & 8 & 60.96202222 & & & \\
\hline \multicolumn{6}{|c|}{ Analise da Variancia - Contrastes Ortogonais - Tratamento T4 } \\
\hline \multicolumn{6}{|c|}{ General Linear Models Procedure } \\
\hline Source & DF & Sum of Squares & Mean Square & F Value & $\operatorname{Pr}>F$ \\
\hline Model & 2 & 21,62015556 & 10.81007778 & 1,69 & $0,2618 \mathrm{~ns}$ \\
\hline Error & 6 & 38,39240000 & 6,39873333 & & \\
\hline Corrected Total & 8 & 60,01255556 & & & \\
\hline \multicolumn{6}{|c|}{ Analise da Variancia - Contrastes Ortogonais - Tratamento T5 } \\
\hline \multicolumn{6}{|c|}{ General Linear Models Procedure } \\
\hline Source & $\overline{\mathrm{DF}}$ & Sum of Squares & Mean Square & F Value & $\operatorname{Pr}>\mathrm{F}$ \\
\hline Model & 2 & 13,52562222 & 6,76281111 & 0.97 & $0,4315 \mathrm{~ns}$ \\
\hline Error & 6 & 41,83173333 & 6,97195556 & & \\
\hline Corrected Total & 8 & 55.35735556 & & & \\
\hline
\end{tabular}


Analise da Variancia - Contrastes Ortogonais - Tratamento T6

General Linear Models Procedure

\begin{tabular}{|c|c|c|c|c|c|}
\hline Source & DF & Sum of Squares & Mean Square & F Value & Pr $>F$ \\
\hline Model & 2 & 14,79442222 & 7,39721111 & 0,83 & $0,4816 \mathrm{~ns}$ \\
\hline Error & 6 & 53,64946667 & 8,94157778 & & \\
\hline Corrected Total & 8 & 68,44388889 & & & \\
\hline
\end{tabular}

Tabela 17: Análise da variància para o efeito acúmulo da trealose endógena pelas leveduras.

\begin{tabular}{|c|c|c|c|c|c|}
\hline \multicolumn{7}{|c|}{$\begin{array}{c}\text { Analise da Variancia - Contrastes Ortogonais } \\
\text { General Linear Models Procedure }\end{array}$} \\
\hline Source & DF & Sum of Squares & Mean Square & F Value & Pr $>$ F \\
\hline Model & 8 & 7,94773333 & 0,99346667 & 100,05 & $0,0001^{* *}$ \\
\hline Error & 18 & 0,17873333 & 0,00992963 & & \\
\hline Corrected Total & 26 & 8,12646666 & & & \\
\hline \multicolumn{7}{|c|}{ CONTRAST Statement Results } & & \\
\hline Contrast & DF & Contrast SS & Mean Square & F Value & Pr $>$ F \\
\hline TA x IZ-1904 & 1 & 6,30125000 & 6,30125000 & 634,59 & $0,0001^{* *}$ \\
\hline TA x SA & 1 & 0,03380000 & 0,03380000 & 3,40 & $0,0816 \mathrm{~ns}$ \\
\hline IZ-1904 x SA & 1 & 5,41205000 & 5,41205000 & 545,04 & $0,0001^{* *}$ \\
\hline
\end{tabular}

Tabela 18: Análise da variància para o efeito manutenção da viabilidade celular pelas leveduras aos 10 dias após liofilização.

\begin{tabular}{|c|c|c|c|c|c|}
\hline \multicolumn{7}{|c|}{ Analise da Variancia - Contrastes Ortogonais - Tratamento TI } \\
General Linear Models Procedure \\
\hline Source & DF & Sum of Squares & Mean Square & F Value & Pr > F \\
\hline Model & 2 & 30,33326667 & 15,16663333 & 1.24 & $0,3545 \mathrm{~ns}$ \\
\hline Error & 6 & 73,46593333 & 12,24432222 & & \\
\hline Corrected Total & 8 & 103,79920000 & & & \\
\hline
\end{tabular}




\begin{tabular}{|c|c|c|c|c|c|}
\hline \multicolumn{6}{|c|}{$\begin{array}{c}\text { Analise da Variancia - Contrastes Ortogonais - Tratamento T2 } \\
\text { General Linear Models Procedure }\end{array}$} \\
\hline Source & $\mathrm{DF}$ & Sum of Squares & Mean Square & F Value & $\operatorname{Pr}>F$ \\
\hline Model & 2 & 15,73135556 & 7,86567778 & 1.20 & $0,3656 \mathrm{~ns}$ \\
\hline Error & 6 & 39,47680000 & 6.57946667 & & \\
\hline Corrected Total & 8 & 55,20815556 & & & \\
\hline \multicolumn{6}{|c|}{ General Linear Models Procedure } \\
\hline Source & $\mathrm{DF}$ & Sum of Squares & Mean Square & F Value & $\mathrm{Pr}>\mathrm{F}$ \\
\hline Model & 2 & 30,64435556 & 15,32217778 & 1,59 & $0,2790 \mathrm{~ns}$ \\
\hline Error & 6 & 57,77140000 & 9,62856667 & & \\
\hline Corrected Total & 8 & 88.41575556 & & & \\
\hline \multicolumn{6}{|c|}{$\begin{array}{c}\text { Analise da Variancia - Contrastes Ortogonais - Tratamento T4 } \\
\text { General Linear Models Procedure }\end{array}$} \\
\hline Source & $\overline{\mathrm{DF}}$ & Sum of Squares & Mean Square & F Value & $\operatorname{Pr}>F$ \\
\hline Model & 2 & 70,05475556 & 35,02737778 & 1,70 & $0,2597 \mathrm{~ns}$ \\
\hline Error & 6 & 123,48560000 & 20,58093333 & & \\
\hline Corrected Total & 8 & 193,54035556 & & & \\
\hline \multicolumn{6}{|c|}{$\begin{array}{c}\text { Analise da Variancia - Contrastes Ortogonais - Tratamento T5 } \\
\text { General Linear Models Procedure }\end{array}$} \\
\hline Source & DF & Sum of Squares & Mean Square & F Value & $\operatorname{Pr}>F$ \\
\hline Model & 2 & 25,51546667 & 12,75773333 & 1,17 & $0,3730 \mathrm{~ns}$ \\
\hline Error & 6 & 65,56873333 & 10,92812222 & & \\
\hline Corrected Total & 8 & 91,08420000 & & & \\
\hline \multicolumn{6}{|c|}{ Analise da Variancia - Contrastes Ortogonais - Tratamento T6 } \\
\hline Source & $\mathrm{DF}$ & Sum of Squares & Mean Square & F Value & $\operatorname{Pr}>F$ \\
\hline Model & 2 & 11.00468889 & 5,50234444 & 0,49 & $0,6366 \mathrm{~ns}$ \\
\hline Error & 6 & 67,74386667 & 11,29064444 & & \\
\hline Corrected Total & 8 & 78.74855556 & & & \\
\hline
\end{tabular}

